\title{
Isotopic Power Materials Development Quarterly Progress Report for Period Ending December 31, 1976
}

\author{
A. C. Schaffhauser
}




\section{DISCLAIMER}

This report was prepared as an account of work sponsored by an agency of the United States Government. Neither the United States Government nor any agency Thereof, nor any of their employees, makes any warranty, express or implied, or assumes any legal liability or responsibility for the accuracy, completeness, or usefulness of any information, apparatus, product, or process disclosed, or represents that its use would not infringe privately owned rights. Reference herein to any specific commercial product, process, or service by trade name, trademark, manufacturer, or otherwise does not necessarily constitute or imply its endorsement, recommendation, or favoring by the United States Government or any agency thereof. The views and opinions of authors expressed herein do not necessarily state or reflect those of the United States Government or any agency thereof. 


\section{DISCLAIMER}

Portions of this document may be illegible in electronic image products. Images are produced from the best available original document. 


\section{Printed in the United States of America. Available from National Technical Information Service \\ U.S. Department of Commerce \\ 5285 Port Royal Road, Springfield, Virginia 22161 \\ Price: Printed Copy $\$ 5.50$; Microfiche $\$ 3.00$}

This report was prepared as an account of work sponsored by the United States Government. Neither the United States nor the Energy Research and Development Administration/United States Nuclear Regulatory Commission, nor any of their employees, nor any of their contractors, subcontractors, or their employees, makes any warranty, express or implied, or assumes any legal liability or responsibility for the accuracy, completeness or usefulness of any information, apparatus, product or process disclosed, or represents that its use would not infringe privately owned rights. 
ORNL/TM-5882

Contract No. W-7405-eng-26

METALS AND CERAMICS DIVISION

\title{
ISOTOPIC POWER MATERIALS DEVELOPMENT QUARTERLY PROGRESS
} REPORT FOR PERIOD ENDING DECEMBER 31, 1976

A. C. Schaffhauser

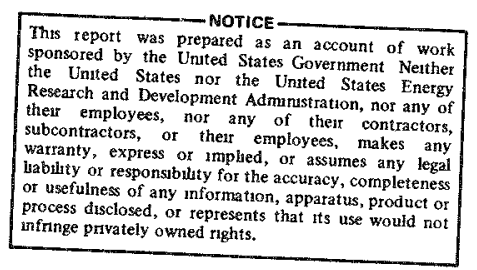

Date Published: June 1977

\author{
OAK RIDGE NATIONAL LABORATORY \\ Oak Ridge, Tennessee 37830 \\ operated by \\ UNION CARBIDE CORPORATION \\ for the
}

ENERGY RESEARCH AND DEVELOPMENT ADMINISTRATION

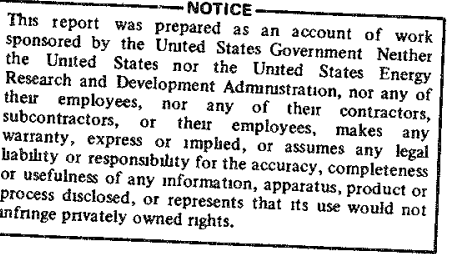


FOREWORD

This report is the fifth in a series of quarterly reports for Technology and Space Applications materials programs conducted by the Metals and Ceramics Division of Oak Ridge National Laboratory for the Nuclear Research and Applications Division of ERDA. These quarterly reports replace the monthly and annual reports previously issued on this work. The quarterly reports will provide a more detailed technical discussion of work in progress than was possible in the monthly reports. Significant technical highlights are reported to ERDA and their contractors on a monthly basis in the Technical Highlights of Isotopic Power Materials DeveZopment at Oak Ridge National Laboratory reports, issued at CF memo reports, with limited distribution.

This quarterly report contains seven chapters: (1) "High-Temperature Alloys for Space Isotopic Heat Sources," Activity No. KJ 0601010 , 189a No. 01405; (2) "Physical and Mechanical Metallurgy of Heat-Source Containment Materials," Activity No. KJ 060101 0, 189a No. 01406;

(3) "Curium-244 Fuel Development," Activity No. KJ 060201 0, 189a No. 01367; (4) "Terrestrial Radioisotopes Applications Development," Activity No. KJ 060100 0, 189a No. 01367; (5) "Selenide Isotope Generator System Support," Activity No. KJ 070202 0, 189a No. 01320; (6) "Isotope Brayton System Materials Support," Activity No. KJ 070201 0, 189a No. 01319; and (7) "Space Nuclear F1ight Systems Hardware," Activity No. KJ 0703000 , 189a No. 01322.

Recent previous reports covering work on these programs are listed below:

Isotopic Power Materials Development Quarterly Reports

ORNL/TM-5285 Period Ending December 31, 1975

ORNL/TM-5482 Period Ending March 31, 1976

ORNL/TM-5569 Period Ending June 30, 1976

ORNL/TM-5810 Period Ending September 30, 1976

Isotopic Power Materials Annual Report

ORNL-TM-5116 Period Ending June 30, 1975 
Isotopic Power Materials Development Monthly Reports

$\begin{array}{ll}\text { ORNL-TM-4859 } & \text { January 1975 } \\ \text { ORNL-TM-4890 } & \text { February 1975 } \\ \text { ORNL-TM-4918 } & \text { March 1975 } \\ \text { ORNL-TM-4953 } & \text { Apri1 1975 } \\ \text { ORNL-TM-4983 } & \text { May 1975 } \\ \text { ORNL-TM-5066 } & \text { July 1975 } \\ \text { ORNL-TM-5103 } & \text { August 1975 } \\ \text { ORNL-TM-5150 } & \text { September 1975 }\end{array}$

Copies of these reports are available from the Energy Reserach and Development Administration, Technical Information Center, P.0. Box 62, Oak Ridge, Tennessee 37830. 
CONTENTS

SUMMARY . . . . . . . . . . . . . . . . . . . . . v vii

1. HIGH-TEMPERATURE ALLOYS FOR SPACE ISOTOPIC HEAT SOURCES . . . . . 1

1.1 Introduction . . . . . . . . . . . . . . . . 1

1.2 Iridium Alloys . . . . . . . . . . . . . . . . . . 1

1.2.1 Development of Improved Iridium Alloys . . . . . . . I

1.2.1.1 Alloy Preparation and Fabrication . . . . 1

1.2.1.2 Tensile Properties . . . . . . . . . 3

1.2.1.3 Impact Properties ........... 4

1.2.2 Weldability of Improved Iridium Alloys . . . . . . 8

1.2.3 Selection of An Improved Iridium Alloy for

1981-1983 Flight System........... . 11

1.3 Pt-Rh-W Alloys . . . . . . . . . . . . . . 13

1.3.1 Pt-3008 Scale-Up and Fabrication Development . . . 13

1.3.2 Characterization of Pt-3008 Scale-Up Heats . . . . 16

1.3.3 Welding of Pt-3008 Alloy . . . . . . . . 22

1.4 Ruthenium and Rhodium Alloys . . . . . . . . . . . . . 23

1.4.1 Rhodium-Ruthenium Alloys . . . . . . . . . 23

1.5 References . . . . . . . . . . . . . . 24

2. PHYSICAL AND MECHANICAL METALLURGY OF HEAT-SOURCE

CONTAINMENT MATERIALS . . . . . . . . . . . . . . . . 27

2.1 Introduction . . . . . . . . . . . . . . . . . . 27

2.2 Characterization of Impact Properties . . . . . . . . 27

2.2.1 Effect of Test Temperature on Impact

2.2.2 Effect of Long-Term Heat Treatment at $1330^{\circ} \mathrm{C}$

on Impact Properties of Ir-0.3\% W Alloys . . . . . 29

2.2.3 Impact Properties of $\mathrm{Ir}-0.3 \% \mathrm{~W}$ Alloys Under

Abnormal Conditions ............ . 29

2.3 Environmental and Impurity Effects . . . . . . . . . 32

2.3.1 Air Oxidation of Iridium Alloys . . . . . . . . 32

2.3.2 Pt-3008/Graphite Compatibility . . . . . . . 33

2.4 Microanalysis Studies . . . . . . . . . . . 36

2.4.1 Analysis of Iridium Cladding from Impacted

Simulant Fuel Sphere Assemblies . . . . . . . 36

2.4.1.1 Introduction ............ 36 
2.4.1.2 Analysis and Results ......... 36

2.4.1.3 Summary and Conclusions . . . . . . 44

2.4.2 Analysis of Precipitate-Matrix Interfaces in

$\operatorname{Ir} 0.3 \%$ W $0.1 \%$ Th Alloys . . . . . . . . . 56

2.5 References................. . . . 58

3. CURIUM-244 FUEL DEVELOPMENT . . • . . • . . . . . . . . 61

3.1 Introduction . . . . . . . . . . . . . . . 61

3.2 Compatibility Test Matrix . . . . . . . . . . . 61

3.3 Fuel Specimen Fabrication . . . . . . . . . . . 61

3.4 References . . . . . . . . . . . . . . . 62

4. SELENIDE ISOTOPE GENERATOR SYSTEM SUPPORT . . . . . . . . . 63

4.1 Introduction . . . . . . . . . . . . . . . 63

4.2 Isolation Hot Frame Fabrication Development . . . . . . . 63

4.3 Compatibility Studies . . . . . . . . . . . . 64

4.3.1 Initial Compatibility Screening Tests . . . . . . 64

4.3.2 Microanalysis Characterization . . . . . . . . 66

4.3.2.1 Exposure of Pt-3008 to Vapor

from $\mathrm{Cu}_{2} \mathrm{Se}$........... 66

4.3.2.2 Exposure of Pt-3008 to Fiberfrax

Insulation . . . . . . . . . . 68

4.4 Insulation Characterization . . . . . . . . . . 73

4.5 References . . . . . . . . . . . . . 74

5. ISOTOPE BRAYTON SYSTEM MATERIALS SUPPORT . . . . . . . . . . 75

5.1 Introduction . . . . . . . . . . . . . . 75

$5.2 \mathrm{C}-103$ Gaseous Interactions . . . . . . . . . . . 75

5.2.1 Creep Properties of $\mathrm{C}-103$ in Contaminating

Environments ............. 75

5.2.2 Kinetics of Gaseous Absorption in C-103 . . . . . 78

5.2.3 Tensile Properties of $\mathrm{C}-103$ in Contaminating

Environments ............. 78

5.3 Welding and Brazing . . . . . . . . . . . . 80

5.4 References . . . . . . . . . . . . . . . . 82

6. SPACE NUCLEAR FLIGHT SYSTEMS HARDWARE . . . . . . . . . . . 83

6.1 Introduction . . . . . . . . . . . . . . . . . . 83

6.2 Production of Ir $-0.3 \%$ W Forming Disks and Foil . . . . . . 83

6.3 Grain Growth in Ir-0.3\% W Alloys . . . . . . . . . . . 83

6.4 Impact Properties of Production Material . . . . . . . . 86

6.5 References .................. . . 91 


\section{SUMMARY}

\section{HIGH-TEMPERATURE ALLOYS FOR SPACE ISOTOPIC HEAT SOURCES}

Optimization of dopant additions for improved iridium alloys for 1981-1983 flight missions was completed. Two alloy systems were selected for final characterization and qualification: arc-melted DOP-26 (Ir $-0.3 \% \mathrm{~W}$

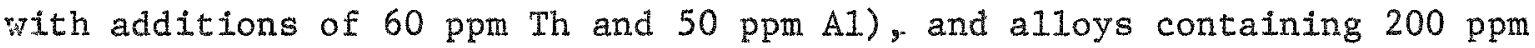
Th prepared either by arc melting (DOP-14-1 or DOP-27 also containing 50 ppm A1) or electron-beam melting (DOP-28). The tensile impact ductility at $1350^{\circ} \mathrm{C}$ and $85 \mathrm{~m} / \mathrm{sec}(280 \mathrm{fps}$ ) of these alloys after the standard $19 \mathrm{hr}$ at $1500^{\circ} \mathrm{C}$ thermal exposure was greater than $34 \%$ as compared to $15-23 \%$ for the current electron-beam-melted DOP 4 alloy production material and $10 \%$ for undoped material. After a severe thermal exposure of $1 \mathrm{hr}$ at $1800^{\circ} \mathrm{C}$, the DOP-14 alloy retained $25 \%$ ductility as compared to 13.5 for the DOP-26 alloy. However, preliminary weldability screening tests show that iridium alloys containing thorium levels of $100 \mathrm{ppm}$ or greater are subject to weld centerline hot cracking. The weld cracking correlated with the quantity of percipitates in the fusion zone which increased with increasing thorium content and was greater than in the base metal. Based on these results and the qualification schedule requirements for an improved iridium alloy for the 1981 Improved Multihundred Watt (MHW) heat source and the 1983 General Purpose Heat Source (GPHS), the DOP-26 alloy was selected for fabrication scale-up. However, both the DOP-26- and DOP-14-type alloys will be supplied to LASL for fuel compatibility testing. If the weldability of the $200 \mathrm{ppm}$ Th alloys can be improved, these alloys may be substituted at a later date to allow higher temperature exposures.

Fabrication and characterization of the second Pt-3008 consumablearc-melted scale-up heat (E2X) was completed. Fabrication of a commerclally induction-melted and cast ingot (IMPI-1) was also completed. The fabrication yield for these ingots was greater than $70 \%$, and $8.7 \mathrm{~kg}$ (19.3 Ib) of sheet were supplied for characterization and fabrication development. Tensile tests of sheet from the second scale-up heat after a 1-hr vacuum anneal at $1200^{\circ} \mathrm{C}$ showed the typical increase in ductility from $15 \%$ at room temperature to $30-40 \%$ at $150-900^{\circ} \mathrm{C}$, a ductility minimum 
viii

of $15 \%$ at $1100^{\circ} \mathrm{C}$, and increase in ductility to greater than $40 \%$ at $1316^{\circ} \mathrm{C}$. Aging at $1100^{\circ} \mathrm{C}$ for $1000 \mathrm{hr}$ in a static vacuum or $200 \mathrm{hr}$ in hydrogen eliminated the ductility minimum in tensile tests at $1100^{\circ} \mathrm{C}$.

Fabrication studies of arc-melted rhodium-ruthenium alloys show that alloys containing up to $45 \% \mathrm{Ru}$ can be fabricated to plate. Alloys highex in ruthenium were not fabricable by conventional techniques due to their hexagonal crystal structure.

2. PHYSICAL AND MECHANICAL METALLURGY OF HEAT-SOURCE CONTAINMENT MATERIALS

Tests to determine the effects of impact temperature and long-term high-temperature thermal exposures on the impact ductility of iridium alloys were continued. Tensile impact tests at $1050^{\circ} \mathrm{C}$ and $85 \mathrm{~m} / \mathrm{sec}$ (280 fps) show that the ductility of all alloys was lower than at $1350^{\circ} \mathrm{C}$. Increasing the annealing time from 1 to $19 \mathrm{hr}$ at $1500^{\circ} \mathrm{C}$ significant $1 \mathrm{y}$ lowered the ductility at the low impact temperature. However, the DOP-14 and -26 alloys retained $18-20 \%$ ductility under the worse conditions compared to $9 \%$ for the DOP -4 alloy. Impact tests at $1350^{\circ} \mathrm{C}$ for specimens exposed up to $6000 \mathrm{hr}$ at $1330^{\circ} \mathrm{C}$ in vacuum show that, due to its grain growth resistance, the DOP-14 alloy has about 3 times the impact ductility of the DOP -4 alloy ( $36 \%$ vs $17 \%$ ). After the severe thermal exposure estimated for the emergency cooling condition for Brayton Isotope Power System $\left(60 \mathrm{hr}\right.$ at $1660^{\circ} \mathrm{C}$ ), the DOP-14 alloy retained $23 \%$ impact ductility.

Tensile tests of iridium alloys containing thorium additions exposed in air at 670 and $870^{\circ} \mathrm{C}$ for $1000 \mathrm{hr}$ show no degradation in tensile properties. Metallographic examination of $\mathrm{Pt}-3008$ exposed to graphite for 5 min at $1750-1950^{\circ} \mathrm{C}$, simulating launch pad fire conditions, shows small spherical graphite particles in the matrix for the $1800^{\circ} \mathrm{C}$ exposure, but no indication of eutectic melting. At $1850^{\circ} \mathrm{C}$ and above, platelets of graphite were observed in the Pt-3008 matrix, probably due to localized eutectic reactions. An iridium layer between the $\mathrm{Pt}-3008$ and graphite was not effective in reducing the interaction.

Extensive Auger analysis of DOP-4 iridium sampeles from ThO 2 simulant Fue1 Sphere Assembly (FSA) impact tests shows that high levels of phosphorus contamination may have contributed to the failures observed in some 
of these tests. Samples from FSA impacts MHT-103 and -104 , which showed internal cracks and breaches, had three times the phosphorus contamination near the internal surface compared to samples from the successfuI FSA impacts MHT-90, -91 , and -92 . The Auger peak for thorium was also significantly reduced in the regions of highest phosphorus contamination. Analysis of grain boundary precipitates in an iridium alloy containing $1000 \mathrm{ppm}$ Th, using a fine-beam scanning Auger microprobe, showed that the precipitate-matrix interface is about three times higher in thorium than the grain boundary.

\section{CURIUM-244 FUEL DEVELOPMENT}

Preparation for compatibility testing of ${ }^{244} \mathrm{Cm}_{2} \mathrm{O}_{3}$ with tensile specimens of potential cladding materials has been resumed. The cladding materials and capsules were fabricated previously; however, three new alloys will be included in the revised test matrix. An extrusion technique for fabrication of the rectangular ${ }^{244} \mathrm{Cm}_{2} \mathrm{O}_{3}$ fuel specimens appears to be a promising alternative to the previously unsuccessful hot pressing techniques.

\section{SELENIDE ISOTOPE GENERATOR SYSTEM SUPPORT}

Pt-3008 sheet for the bellows of the Isolation Hot Frame (IHF) of the Selenide Isotope Generator (SIG) ground demonstration system has been supplied to a commercial bellows fabricator for forming development. Fabrication of the required tooling for forming has been completed.

The initial compatibility screening tests of $\mathrm{Pt}-3008$ with potentially incompatible materials in the system were completed for $1000 \mathrm{hr}$ at 800 , 950, and $1100^{\circ} \mathrm{C}$ exposures under the "worse case" conditions. No degradation of mechanical properties was observed in $\mathrm{Pt}-3008$ samples in the vicinity of Min-K insulation in contact with graphite. Specimens in direct contact with Fiberfrax insulation had less than half the ductility of control specimens. Auger analysis of the grain boundary fracture surface showed $1-5$ at. $\% \mathrm{~S}$ and $\mathrm{P}$. Specimens exposed to vapor from $\mathrm{Cu}_{2} \mathrm{Se}$ were completely brittle due to grain boundary corrosion and embrittlement from Se. A second series of tests under more typical conditions is being prepared. 
We completed an assessment of commercially avallable fibrous thermal insulations of interest for the SIG system. Recomendations of additional data required to insure successful utilization are given. Chemical and microstructural characterization of the insulations currently proposed for the GDS show potantial chemicat, and high-temperature stability problems.

\section{ISOTOPE BRAYTON SYSTEM MATERIAIS SUPPORT}

Environmental creep testing of $\mathrm{C}-103$ at $878^{\circ} \mathrm{C}$ and $145 \mathrm{MPa}$ (21 ksi) in a simulated alternator outgassing environment of pyromelitic acid showed a creep rate a factor of 10 higher than in ultrahigh vacuum. Initial parametric tests to determine the factors controlling the accelerated creep were unsuccessful due either to specimen bending or synergistic interactions between the stress and environment. Contamination kinetics studies

on $\mathrm{C}-103$ in $1.3 \times 10^{-3} \mathrm{~Pa}\left(10^{-5}\right.$ torr $)$ Co show a square root of time dependence at 850 and $1000^{\circ} \mathrm{C}$. The contamination rate is diffusion controlled and decreases with decreasing temperature and increasing specimen thickness. The tensile ductility of C-103 specimens contaminated to 4200 ppm $C$ and $O$ under the above conditions is reduced to 1 ess than $5 \%$ at room temperature to $1000^{\circ} \mathrm{C}$.

Additional tensile tests of brazed Hastelloy $X$ specimens show that the strength and ductility are strain rate sensitive with lower properties at slow strain rates.

\section{SPACE NUCLEAR FLIGHT SYSTEMS HARDWARE}

A total of 38 Ir-0.3\% W PICS forming disks (lots TR 512-535) were shipped to MRC this quarter for the SIPS heat source. In addition, we shipped 38 disks previously rejected for flight hardware due to minor defects. Iridium foil was delivered to BCL for vent development studies.

We confirmer that the grain growth behavior of the HD production lots of Iridium sheet was uniform and the same as the developmental DOP-4 sheets. The large grain size observed in the fuel impact tests after aging at LASL is not consistent with our data on sheet samples or samples from simulant FSA tests on the same lot of material. Additional tensile impact tests of 
the HD production lots of the DOP -4 iridium alloy show that the tensile ductility is $19 \pm 4 \%$ elongation for specimens annealed $19 \mathrm{hr}$ at $1500^{\circ} \mathrm{C}$. The number of grain boundaries across the thickness of these specimens ranged from 7-12. The TR lot of recycled iridium (30 ppm Th dopant addition) has an impact elongation and grain size on the lower end of these ranges. 


\section{HIGH-TEMPERATURE ALLOYS FOR SPACE ISOTOPIC HEAT SOURCES*}

\subsection{Introduction}

The objective of this program is to develop and qualify improved alloys for encapsulation of ${ }^{238} \mathrm{PuO}_{2}$ isotope fuels used for heat sources for high-temperature energy conversion systems for space and terrestrial power applications. We are developing a series of high-melting-point, noble-base alloys having the required mechanical properties, oxidation resistance, and stability in a heat-source environment under both operational and potential severe accident conditions. Our activities are divided between improved iridium alloys, Pt-Rh-W alloys, and lighter-weight ruthenium and rhodium alloys. Tasks on these materials include alloy and fabrication development, characterization, and supply of materials and hardware for qualification testing.

\subsection{Iridium Alloys}

\subsubsection{Development of Improved Iridium Alloys - C. T. Liu and H. Inouye}

1.2.1.1 Alloy Preparation and Fabrication. - Previous studies indicate that doping with a high level of thorium or a combination of thorium and aluminum significantly improves the high-velocity impact properties and grain stability of Ir $0.3 \% \mathrm{~W}$ alloys. Based on these results, we have prepared and characterized four additional doped alloys, designated as DOP-14-1, DOP-26, -27 , and -28 , as candidate alloys for improved MHW and genera1-purpose heat source applications. The starting material for these alloys was electron-beam melted, and dopants were added as arc-melted master ailoys. The alloy composition and preparation are described below.

(1) DOP-14-1 - This is an Ir $-0.3 \% \mathrm{~W}$ alloy doped with $200 \mathrm{ppm}$ Th. This alloy was prepared for the purpose of further characterizing the metallurgical and mechanical properties of the DOP-14 alloy developed previously. ${ }^{1}$ The alloy button was arc melted six times then drop cast into the full-size

\footnotetext{
*Progress on work performed under Activity No. KJ $0601010,189 \mathrm{a}$ No. 01405 .
} 
ingot $[19 \times 19 \times 54 \mathrm{~mm}(3 / 4 \times 3 / 4 \times 21 / 8$ in. $)]$. The alloy stuck to the copper hearth several times during arc melting. However, the alloy button was acid etched after each melt to minimize contamination.

(2) DOP-27 - This alloy, which is a modified DOP-14 composition, was doped with $200 \mathrm{ppm}$ Th and $50 \mathrm{ppm} \mathrm{Al}$. The alloy button was arc melted six times then drop cast into the full-size ingot. The alloy stuck slightly to the copper hearth during arc melting.

(3) DOP-28 - On the live fuel compatibility test at LASL, tungsten has been found sometimes in the metallic crust at the vent ports. ${ }^{2}$ It is possible that the tungsten may come from the Ir $-0.3 \% \mathrm{~W} \mathrm{PICS}$, so we prepared the DOP-28 alloy, which is pure iridium doped with $200 \mathrm{ppm}$ Th, for evaluation. The alloy button was prepared by electron-beam melting and drop casting into the full-size ingot.

(4) DOP-26 - This Ir -0.3\% W alloy, which may be considered as an "upgraded" DOP-4, was doped with $60 \mathrm{ppm}$ Th and $50 \mathrm{ppm} \mathrm{Al.} \mathrm{The} \mathrm{alloy} \mathrm{but-}$ ton was arc melted six times then drop cast into the full-size ingot. The alloy stuck to the copper hearth several times during arc melting.

The four ingots were separately canned in a molybdenum frame and fabricated into $0.074-\mathrm{cm}-(0.030-i n .-)$ thick sheets using the WGD production rolling schedule. ${ }^{3}$ All the sheets had good quality. The dopant concentration and trace impurities in these alloys were determined by SSMS analysis; the results are shown in Table 1.1. The tungsten content was determined from iridium-tungsten standards, and AI, Th, Ni, Fe, Ta, Pt, and $R$ were measured by comparison with the tungsten in the samples. Although the alloys stuck to the copper hearth during arc melting, DOP-14-1 contains only $50 \mathrm{ppm} \mathrm{Cu}$ and the rest of the alloys contain less than $10 \mathrm{ppm}$. The acid etching after each melt appears to have minimized the contamination. The aluminum and thorium contents in DOP-14-1, DOP-26, and -27 are quite close to their nominal amount, indicating that the dopant concentration can be well controlled by arc melting. The reported thorium content in electron-beam-melted DOP-28 is much lower than the nominal content, probably due to lack of the reference standard (tungsten) in this alloy. The $\mathrm{Fe}, \mathrm{Cr}$, and $\mathrm{Ni}$ contents are quite low at a level $\leq 10 \mathrm{ppm}$ in these alloys. 
Table 1.1. Spark Source Mass Spectroscopic (SSMS) Analysis of Alloy Specimens DOP-14-1, DOP $-26,-27$, and -28

\begin{tabular}{lcccc}
\hline & \multicolumn{4}{c}{ Concentration by } \\
\cline { 2 - 5 } Element & DOP-14-1 & DOP-26 & DOP-27 & DOP-28 \\
\hline & 1 & - & - & 3 \\
$\mathrm{Ag}$ & 1 & 40 & 40 & 1 \\
$\mathrm{~A} 1$ & $<0.1$ & $<0.1$ & $<0.1$ & $<0.1$ \\
$\mathrm{Ca}$ & 0.1 & 3 & 0.5 & 0.3 \\
$\mathrm{Cr}$ & 50 & 1 & 1 & 5 \\
$\mathrm{Cu}$ & 1 & 10 & 10 & 1 \\
$\mathrm{Fe}$ & - & $<1$ & - & - \\
$\mathrm{Hf}$ & - & 30 & 30 & - \\
$\mathrm{K}$ & 3 & 3 & 3 & 3 \\
$\mathrm{Mo}$ & $<0.1$ & 0.1 & $\leq 0.1$ & $<0.1$ \\
$\mathrm{Na}$ & 1 & 5 & 1 & 1 \\
$\mathrm{Ni}$ & $<0.1$ & $<0.3$ & $<0.3$ & $<0.1$ \\
$\mathrm{P}$ & $<0.1$ & $<0.1$ & $<0.1$ & $<0.1$ \\
$\mathrm{Pd}$ & 50 & 50 & 100 & 20 \\
$\mathrm{Pt}$ & 10 & 15 & 15 & 3 \\
$\mathrm{Rh}$ & $<0.1$ & 0.5 & 60 & $<0.1$ \\
$\mathrm{Ru}$ & 0.3 & 1 & 1 & 0.5 \\
$\mathrm{~S}$ & $<1$ & 1 & 1 & 1 \\
$\mathrm{Si}$ & 20 & $\leq 10$ & $\leq 10$ & 20 \\
$\mathrm{Ta}$ & 200 & 50 & 150 & 115 \\
$\mathrm{Th}$ & $<1$ & - & - & $<1$ \\
$\mathrm{Ti}$ & 2000 & 2200 & 2200 & 20 \\
W & & & & \\
\hline
\end{tabular}

1.2.1.2 Tensile Properties. - The tensile properties of these four alloys were determined at $650^{\circ} \mathrm{C}$ after a standard heat treatment of $\mathrm{I} \mathrm{hr}$ at $1500^{\circ} \mathrm{C}$. The results are presented in Table 1.2 and are compared with those of undoped alloy WG. The yield and tensile strengths of doped alloys appear to increase with the total amount of aluminum and thorium, and is higher than that of undoped WG alloy. WG specimens had $30.1 \%$ elongation and the doped alloys had 35.4 to $39.5 \%$ at $650^{\circ} \mathrm{C}$. Most significant1y, all four doped alloys showed mainly transgranular fracture while the undoped alloy exhibited mainly grain-boundary separation at $650^{\circ} \mathrm{C}$. It was noted that necking was visible on the fracture section of these doped alloys at $650^{\circ} \mathrm{C}$. 
Table 1.2. Tensile Properties ${ }^{\mathrm{a}}$ of Undoped and Doped Iridium and Ir $-0.3 \% \mathrm{~W}$ Sheet Specimens ${ }^{\mathrm{b}}$ Tested at $650^{\circ} \mathrm{C}$

\begin{tabular}{|c|c|c|c|c|c|}
\hline \multirow{2}{*}{$\begin{array}{l}\text { Alloy } \\
\text { Number }\end{array}$} & \multirow{2}{*}{$\begin{array}{l}\text { Nominal Dopant } \\
\text { Concentration } \\
\text { (ppm) }\end{array}$} & \multicolumn{2}{|c|}{ Strength, MPa(psi) } & \multirow{2}{*}{$\begin{array}{c}\text { Elongation } \\
(\%)\end{array}$} & \multirow{2}{*}{$\begin{array}{l}\text { Fracture } \\
\text { Mode }\end{array}$} \\
\hline & & Yield & Tensile & & \\
\hline$W^{d}$ & None & $51.0(7,400)$ & $487.8(70,800)$ & 30.1 & Mainly GBS \\
\hline $\mathrm{DOP}-26^{\mathrm{e}}$ & $60 \mathrm{Th}, 50 \mathrm{Al}$ & $75.8(11,000)$ & $529.8(76,900)$ & 35.4 & Mainly $T F$ \\
\hline$D O P-28^{f}$ & $200 \mathrm{Th}$ & $95.1(13,800)$ & $513.3(74,500)$ & 39.3 & Mainly TF \\
\hline $\mathrm{DOP}-14^{\mathrm{e}}$ & $200 \mathrm{Th}$ & $93.7(13,600)$ & $556.0(80,700)$ & 37.4 & Mainly $\mathrm{TF}$ \\
\hline DOP $-27^{e}$ & $200 \mathrm{Th}, 50 \mathrm{Al}$ & $97.2(14,100)$ & $564.3(81,900)$ & 37.5 & Mainly $\mathrm{TF}$ \\
\hline $\begin{array}{l}{ }^{A} \\
{ }^{C}{ }_{G} \\
d_{r}\end{array}$ & $\begin{array}{l}\text { ed at a cross } \\
\text { specimens wer } \\
=\text { grain-bound } \\
\text { ped Ir } 0.3 \% \mathrm{~W} \\
\text { Ir-0.3\% W a }\end{array}$ & $\begin{array}{l}\text { d speed of } \\
\text { separatior } \\
\text { soy prepar }\end{array}$ & $\begin{array}{l}54 \mathrm{~mm} / \mathrm{min} \\
\text { at } 1500^{\circ} \mathrm{C} \mathrm{b} \\
\mathrm{TF}=\text { transg } \\
\text { by electron }\end{array}$ & $\begin{array}{l}1 \text { in. } / \mathrm{min} \text { ) } \\
\text { ore testin } \\
\text { nular frac } \\
\text { eam meltin }\end{array}$ & in va \\
\hline
\end{tabular}

1.2.1.3 Impact Properties. - Sheet specimens of DOP-14-1, DOP-26, -27 , and -28 were heat treated $19 \mathrm{hr}$ at $1500^{\circ} \mathrm{C}$ then impact tested at $1350^{\circ} \mathrm{C}$ at a velocity of $85 \mathrm{~m} / \mathrm{sec}(280 \mathrm{fps})$. The impact results are presented in Table 1.3 and are compared with undoped WG. AlI doped alloys had more than $34 \%$ elongation and $85 \%$ reduction of area, and their fracture mode was mainly ductile rupture. In comparison, undoped alloy (WG) had $10.7 \%$ elongation and $23 \%$ reduction of area, and its fracture mode was grain-boundary separation. Also, impact properties of the new doped alloys are much better than those of DOP-4-type production material (reported in section 7.4 of this report).

The grain size of these impact specimens was measured with their results shown in Table 1.3. Figure 1.1 shows the grain structure and the precipitates (probably Ir 5 Th) of these alloys. The DOP-26 specimen containing $60 \mathrm{ppm}$ Th and $50 \mathrm{ppm} \mathrm{Al} \mathrm{had} \mathrm{the} \mathrm{coarsest} \mathrm{grain} \mathrm{structure} \mathrm{after}$ being annealed $19 \mathrm{hr}$ at $1500^{\circ} \mathrm{C}$. DOP-27, -28, and DOP-14-1 specimens all contain $200 \mathrm{ppm}$ Th; however, DOP-28, prepared from electron-beam melting without the $0.3 \% \mathrm{~W}$ addition had 16.8 grains across the thickness while 
Table 1.3. Tensile Impact Properties of Doped and Undoped Iridium and Ir $-0.3 \% \mathrm{~W}$ Sheet Specimens Annealed $19 \mathrm{hr}$ at $1500^{\circ} \mathrm{C}$ and Tested at $85 \mathrm{~m} / \mathrm{sec}(280 \mathrm{fps})$ and $1350^{\circ} \mathrm{C}$

\begin{tabular}{|c|c|c|c|c|}
\hline $\begin{array}{l}\text { Alloy } \\
\text { Number }\end{array}$ & $\begin{array}{l}\text { Grain } \\
\text { Size }\end{array}$ & $\begin{array}{l}\text { E1ongation } \\
(\%)\end{array}$ & $\begin{array}{c}\text { Reduction } \\
\text { of Area } \\
(\%)\end{array}$ & Fracture Mode ${ }^{a}$ \\
\hline$W G-202^{d}$ & 5.8 & $10.7^{c}$ & $23^{c}$ & MainIy GBS \\
\hline $\mathrm{DOP}-26^{\mathrm{e}}$ & 13.7 & 38.0 & 94 & $\mathrm{DR}$ \\
\hline$-28^{\mathrm{f}}$ & 16.8 & 34.5 & 85 & DR \\
\hline$-14-1^{e}$ & 19.6 & 37.8 & 92 & $\mathrm{DR}$ \\
\hline$-27^{e}$ & 21.1 & 41.9 & 95 & $\mathrm{DR}$ \\
\hline \multicolumn{5}{|c|}{$\begin{array}{l}a_{D R}=\text { ductile rupture; GBS } \\
\text { separation. } \\
b_{\text {Number of grains across a }} \\
\text { thick sheet. } \\
{ }^{c} \text { Average of two tests. } \\
{ }^{d_{\text {Undoped }} \text { Ir }-0.3 \% \mathrm{~W} \text { alloy. }} \\
\mathrm{e}_{\text {Doped }} \text { Ir }-0.3 \% \mathrm{~W} \text { alloy. } \\
{ }^{\mathrm{E}} \text { Doped iridium. }\end{array}$} \\
\hline
\end{tabular}



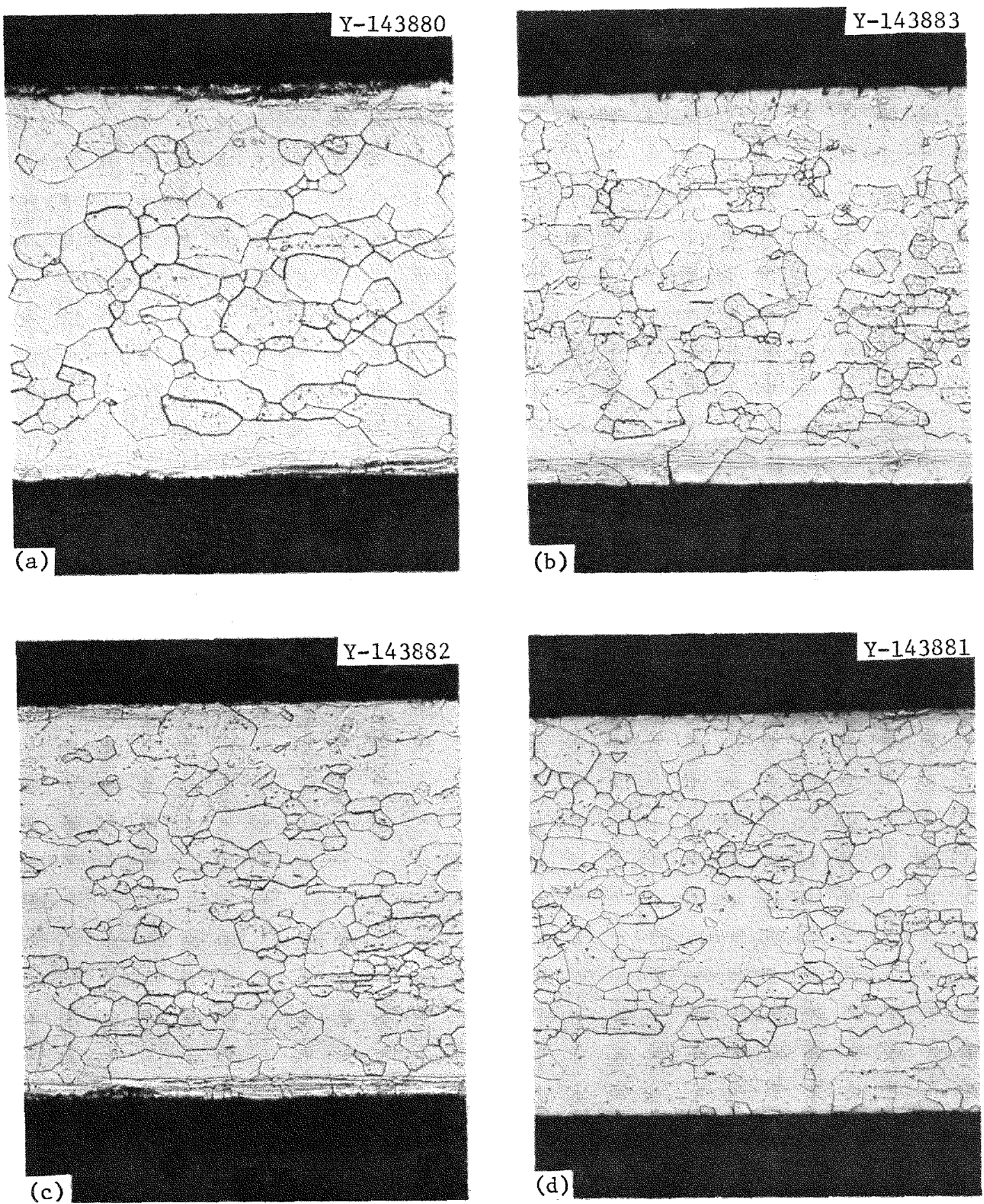

Fig. 1.1. Microstructures of (a) DOP-26, (b) DOP-28, (c) DOP-14-1, and (d) DOP -27 Specimens Annealed 19 hr at $1500^{\circ} \mathrm{C}$. $100 \times$. 
DOP-27, containing an additional $50 \mathrm{ppm}$ Al (prepared by arc melting) had 21.1 grains across the specimen after the same heat treatment.

Tensile impact properties of the doped alloys DOP-4-11, DOP-23, -24 , and -25 were reported previous $1 \mathrm{y}^{4}$ after being annealed 1 and $19 \mathrm{hr}$ at $1500^{\circ} \mathrm{C}$. Table 1.4 summarizes the tensile impact properties of these alloys after a severe heat treatment of $1 \mathrm{hr}$ at $1500^{\circ} \mathrm{C}$ plus $1 \mathrm{hr}$ at $1800^{\circ} \mathrm{C}$ plus $1 \mathrm{hr}$ at $1500^{\circ} \mathrm{C}$. For comparison, the impact properties of undoped WG and thorium-doped WTh-1 are also shown in Table 1.4. The alloys DOP-24, -25 , and DOP-4-11, doped with a combination of $30 \mathrm{ppm}$ Th and 40-200 ppm A1, had better impact properties than those of DOP-23, doped with $40 \mathrm{ppm}$ Al alone, and WTh-1, doped with $50 \mathrm{ppm}$ Th alone. The DOP-24, -25 , and DOP-4-11 specimens had about the same impact properties, indicating that doping with more than $40 \mathrm{ppm}$ A1 had no significant effect on improving the impact properties of Ir-0.3\% W alloy under this severe heat treatment condition. The grain size of these impact specimens was measured with their results also listed in Table 1.4.

Table 1.4. Tensile Impact Properties of Doped and Undoped Ir-0.3\% W Alloy Sheets Tested at $85 \mathrm{~m} / \mathrm{sec}(280 \mathrm{fps})$ and $1350^{\circ} \mathrm{C}$ after

Heat Treatment of $1 \mathrm{hr}$ at $1500^{\circ} \mathrm{C}$ plus $1 \mathrm{hr}$ at $1800^{\circ} \mathrm{C}$ plus $1 \mathrm{hr}$ at $1500^{\circ} \mathrm{C}$

\begin{tabular}{|c|c|c|c|c|c|}
\hline $\begin{array}{l}\text { A1loy } \\
\text { Number }\end{array}$ & $\begin{array}{c}\text { Dopant } \\
\text { Concentration } \\
(\mathrm{ppm})\end{array}$ & $\begin{array}{l}\text { Graif } \\
\text { Size }\end{array}$ & $\underset{(\%)}{\text { Elongation }}$ & $\begin{array}{c}\text { Reduction } \\
\text { of Area } \\
(\%)\end{array}$ & Fracture Mode ${ }^{c}$ \\
\hline WG & None & $2.4^{c}$ & $3.4^{\mathrm{d}}$ & $\sigma^{2}$ & Completely GBS \\
\hline $\mathrm{DOP}-23$ & $40 \mathrm{~A} 1$ & 2.3 & 4.7 & 11 & Main1y GBS \\
\hline WTh-1 & $50 \mathrm{Th}$ & 4.2 & 7.2 & 17 & Mainly GBS \\
\hline DOP -24 & $30 \mathrm{Th}, 100 \mathrm{~A} 1$ & 4.4 & 9.8 & 20 & Mainly GBS \\
\hline DOP-25 & $30 \mathrm{Th}, 200 \mathrm{Al}$ & 4.9 & 10.8 & 21 & Mainly GBS \\
\hline DOP $-4-11^{e}$ & $\mathrm{DOP}-4^{\mathrm{e}}$ plus $40 \mathrm{~A} 1$ & 3.8 & 10.3 & 17 & Mainly GBS \\
\hline \multicolumn{6}{|c|}{ 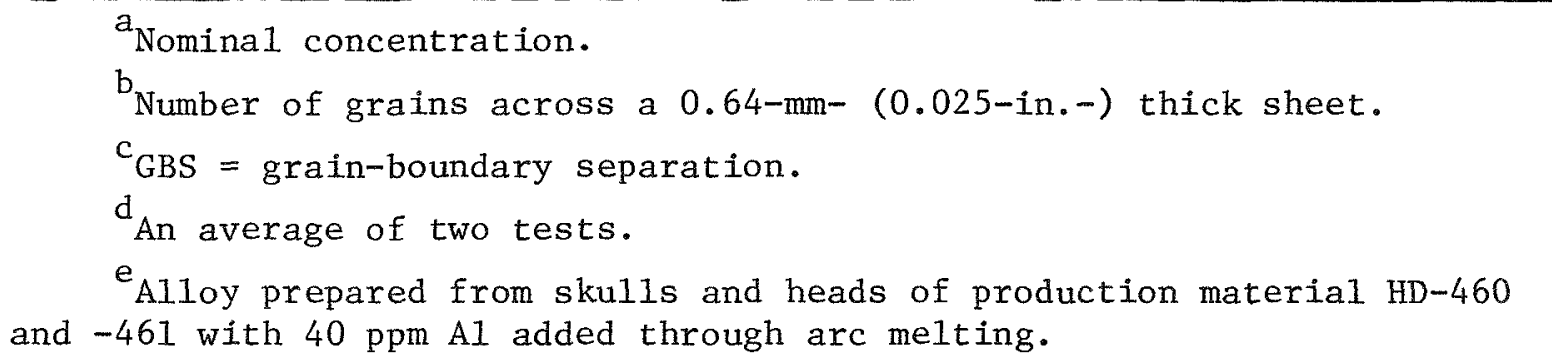 } \\
\hline
\end{tabular}




\subsubsection{Weldability of Improved Iridium Alloys - G. M. Goodwin}

Studies are underway to characterize the weldability of iridium alloys with controlled additions of thorium and aluminum. Table 1.5 summarizes the results of preliminary weldability screening tests. Welds were performed on small coupons of available material and, thus, cannot be expected to accurately predict weldability response of structural welds in typical hardware. Trends, however, should be significant, and alloys showing poor response on these preliminary tests clearly need more detailed weldability characterization. Gas-tungsten arc (GTA) welds were made in a helium atmosphere chamber with lateral oscillation, closely approximating conditions utilized by Mound Laboratory for fueling of hemispheres. ${ }^{5}$

The results of Table 1.5 show a clear dependence of cracking tendency on thorium level. All welds containing thorium levels of $100 \mathrm{ppm}$ or more cracked, while those containing less did not. Aluminum in the amounts added does not appear to influence weldability. No difference in response was noted between electron-beam and GTA welds.

Metallographic examination of a number of weld specimens showed an increase in the amount of second phase particles in the fusion zone as a function of thorium level as compared to previously reported microstructures for the base metal. ${ }^{6}$ Figure 1.2 shows the weld structure typical of EB- and GTA-weld low-thorium alloys. Although the GTA weld shows a generally coarser weld structure, no cracking is observed in either. By comparison, Figure 1.3 shows the structure typical of the higher-thorium-containing alloys. Note the general increase in the amount of second phase particles as the thorium level increases. The particles appear evenly distributed between grain boundaries and grain interiors. The hot cracking follows the weld centerline and shows little, if any, preference between transgranular and intergranular modes. Scanning electron microscopy (SEM) is being performed on fracture surfaces to further characterize this hot cracking behavior. Additional welding development is underway to determine the limiting thorium concentration and optimum weld parameters to prevent hot cracking. 
Table 1.5. Weldability Screening of Doped Iridium Alloys

\begin{tabular}{llll}
\hline \multicolumn{1}{c}{ Alloy } & \multicolumn{1}{c}{$\begin{array}{c}\text { Dopants } \\
(\mathrm{ppm})\end{array}$} & $\begin{array}{c}\text { Weld } \\
\text { Process }\end{array}$ & Results \\
\hline WTh-1 & $50 \mathrm{Th}$ & $\mathrm{EB}$ & no cracking \\
DOP-4-11D & $30 \mathrm{Th}$ & $\mathrm{EB}$ & no cracking \\
DOP-23D & $40 \mathrm{Al}$ & $\mathrm{EB}, \mathrm{GTA}$ & no cracking \\
DOP-24D & $30 \mathrm{Th}, 100 \mathrm{Al}$ & $\mathrm{EB}, \mathrm{GTA}$ & no cracking \\
DOP-25D & $30 \mathrm{Th}, 200 \mathrm{Al}$ & $\mathrm{EB}, \mathrm{GTA}$ & no cracking \\
DOP-26C & $60 \mathrm{Th}, 60 \mathrm{Al}$ & $\mathrm{EB}, \mathrm{GTA}$ & no cracking \\
DOP-22 & $100 \mathrm{Th}$ & $\mathrm{EB}, \mathrm{GTA}$ & cracking \\
DOP-14 & $200 \mathrm{Th}$ & $\mathrm{EB}, \mathrm{GTA}$ & cracking \\
DOP-27C & $200 \mathrm{Th}, 50 \mathrm{Al}$ & $\mathrm{EB}, \mathrm{GTA}$ & cracking \\
DOP-28B & $200 \mathrm{Th}$ & $\mathrm{EB}, \mathrm{GTA}$ & cracking \\
DOP-21 & $500 \mathrm{Th}$ & $\mathrm{EB}, \mathrm{GTA}$ & cracking \\
\hline
\end{tabular}

$a_{\text {Welds in } 0.64-m m(0.025-i n .)}$ sheet; $E B=$ electron beam, GTA = gas tungsten-arc welds in helium atmosphere chamber with lateral torch oscillation.

${ }^{\mathrm{b}} \mathrm{All}$ cracked specimens showed centerline cracking of entire weld bead length.
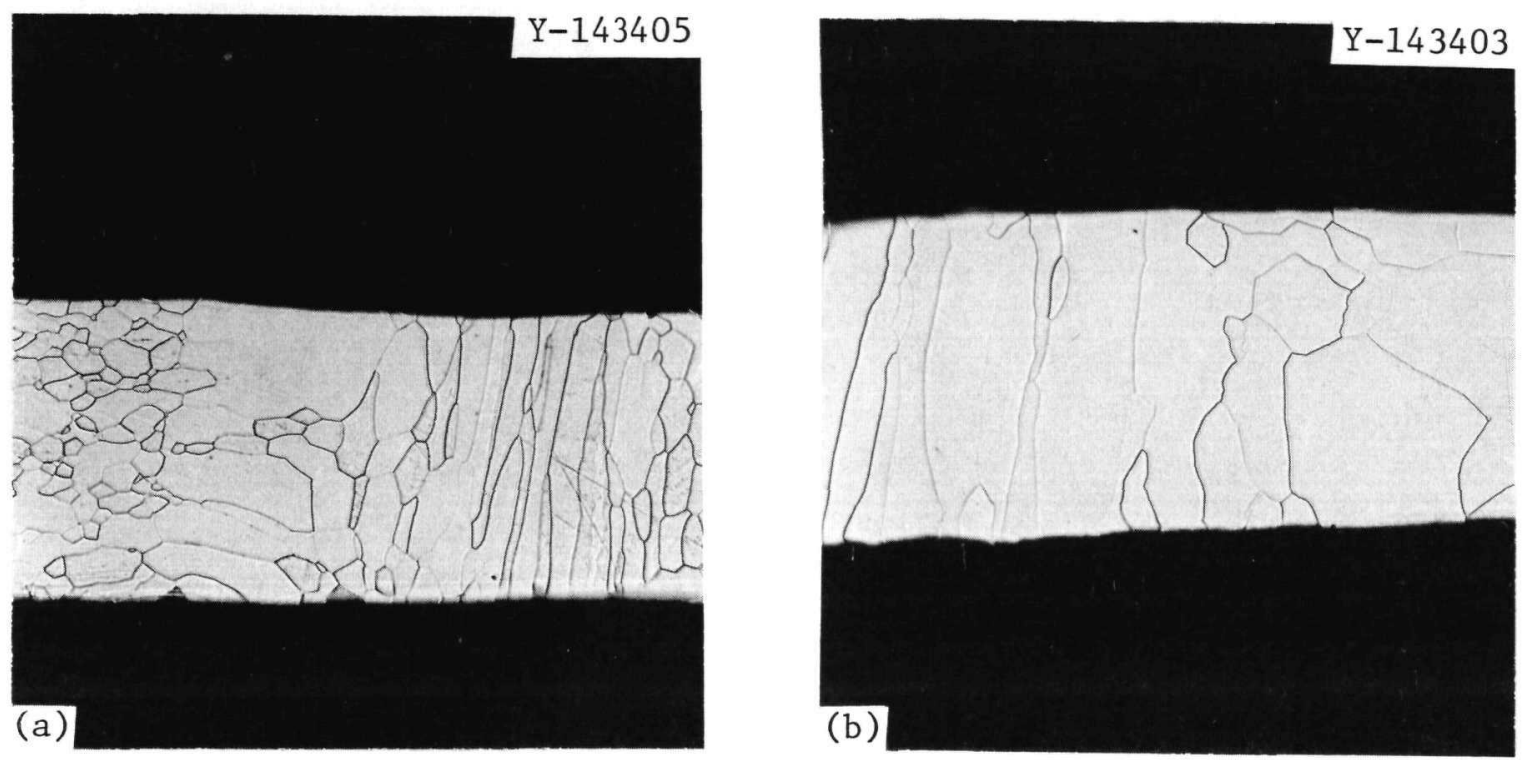

Fig. 1.2. Typical Welds in Doped Iridium Alloy, DOP-25, Containing $30 \mathrm{ppm}$ Th and $200 \mathrm{ppm} \mathrm{Al}$. Note absence of second phase in (a) electronbeam weld and (b) gas tungsten-arc weld. 50x. 

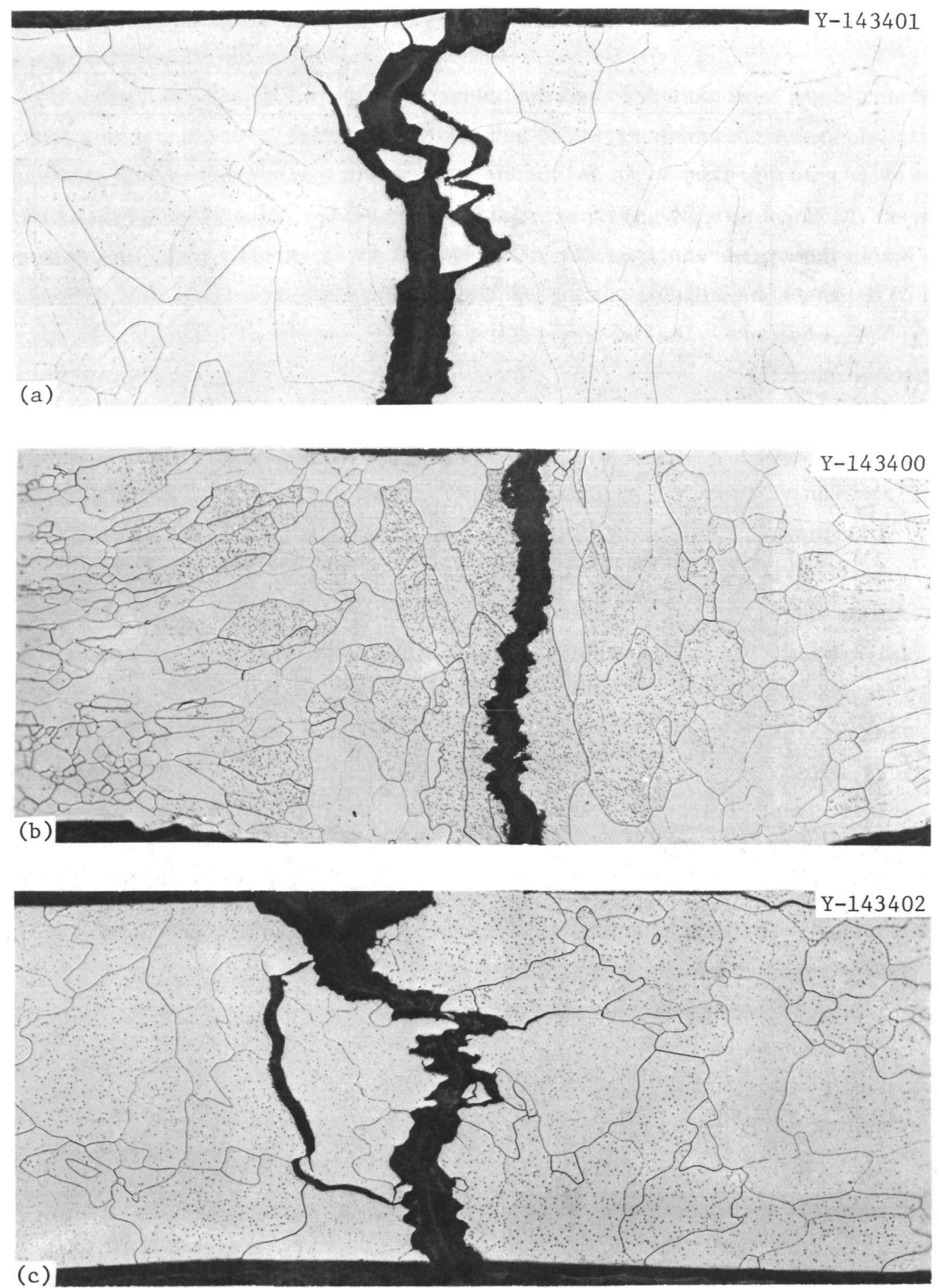

Fig. 1.3. Typical Welds in Doped Iridium Alloys Containing Various Thorium Content Levels. Note increase in second phase particles with increase in thorium content: (a) DOP-22 (100 ppm Th); (b) DOP-14 (200 ppm $\mathrm{Th}$ ); and (c) DOP-21 (500 ppm Th). 100×. 


\subsubsection{Selection of An Improved Iridium Alloy for 1981-1983 F1ight System -} C. T. Liu, H. Inouye, and A. C. Schaffhauser

To meet the development and qualification schedules for an improved iridium alloy for the improved Multihundred Watt (MHW) and General Purpose Heat Source (GPHS) applications, we must select at this time an alloy for more detailed characterization. This alloy must be technologically ready by the second quarter of FY 1978 (January through March) in order to meet the MHW flight mission in FY 1981 and GPHS design and qualification program for a FY-1983 mission. Table 1.6 compares the impact properties of the promising alloys developed recently with the undoped alloy WG and the current HD-type production material (DOP-4 composition, EB melted). Clearly, the impact properties of DOP-26 (doped with $60 \mathrm{ppm}$ Th and $50 \mathrm{ppm} \mathrm{A1}$ ) and DOP-14 (doped with $200 \mathrm{ppm}$ Th) are much superior to the current production material, $\mathrm{HD}$, when impacted at $85 \mathrm{~m} / \mathrm{sec}(280 \mathrm{fps})$ at $1350^{\circ} \mathrm{C}$. The impact properties of DOP-14 are even better than those of DOP-26 after a severe heat treatment at $1800^{\circ} \mathrm{C}$; however, our initial welding studies show that alloys containing $100 \mathrm{ppm}$ Th or more are subject to hot cracking due to extensive precipitation of second-phase particles (probably $\operatorname{ThIr}_{5}$ ) in the fusion zone. Unless the weldability of the DOP-14 alloy can be improved in time, the best alloy for near-term impact property improvement appears to be the DOP-26 a1loy, containing a combination of thorium and aluminum dopants. The DOP-26 alloy also has excellent ductility at lower impact temperatures (see section 2.2.1 of this report). For example, Dop-26 had $30.4 \%$ impact elongation while $\mathrm{HD}$ had only $14.4 \%$ elongation when impacted at $1050^{\circ} \mathrm{C}$ and $85 \mathrm{~m} / \mathrm{sec}$ (280 fps). To retain the beneficial aluminum addition, it is necessary to arc melt the DOP-26 alloy, and the reproducability of this alloy must be demonstrated under production conditions. Further qualification of this alloy will involve fuel compatibility tests at LASL, further demonstration of its weldability at ORNL and Mound Laboratory, and Fuel Sphere Assembly (FSA) impact testing at LASL.

We are continuing welding development on the DOP-14 a1loy and wi11 supply samples of this alloy for fuel compatibility testing at LASL. We recommend that the DOP-4-11 alloy (arc-melted $30 \mathrm{ppm} \mathrm{Th}, 40 \mathrm{ppm}$ Al) be considered as a back-up improved alloy at this time. 
Table 1.6. Tensile Impact Properties of Selected Doped Ir $-0.3 \% \mathrm{~W}$ Alloys Tested at $85 \mathrm{~m} / \mathrm{sec}(280 \mathrm{fps})$ at $1350^{\circ} \mathrm{C}$

\begin{tabular}{|c|c|c|c|c|c|c|c|}
\hline \multirow{3}{*}{ A11oy } & \multirow{3}{*}{$\begin{array}{c}\text { Nomina1 Dopant } \\
\text { Concentration } \\
(\mathrm{ppm})\end{array}$} & \multirow{3}{*}{$\begin{array}{l}\text { Melting } \\
\text { Method }^{2}\end{array}$} & \multicolumn{5}{|c|}{ Impact Results after Indicated Vacuum Heat Treatment } \\
\hline & & & \multicolumn{2}{|c|}{$19 \mathrm{hr}$ at $1500^{\circ} \mathrm{C}$} & \multicolumn{3}{|c|}{$1 \mathrm{hr}$ at $1800^{\circ} \mathrm{C}^{\mathrm{b}}$} \\
\hline & & & $\begin{array}{cc}\underset{\text { Grain }}{\text { Size }} & \text { Elongation } \\
(\%)\end{array}$ & $\begin{array}{l}\text { Fracture } \\
\text { Moded }\end{array}$ & $\begin{array}{l}\text { Grain } \\
\text { Size }\end{array}$ & $\begin{array}{c}\text { Elongation } \\
(\%)\end{array}$ & Moded $^{\text {Fractur }}$ \\
\hline $\begin{array}{l}W G^{e} \\
H^{e}, f \\
\text { DOP-4-11 } \\
\text { DOP-25 } \\
\text { DOP-26 } \\
\text { DOP-14-1 }\end{array}$ & $\begin{array}{l}\text { None } \\
30 \mathrm{Th}, 40 \mathrm{~A} 1_{\mathrm{g}}^{\mathrm{g}} \\
30 \mathrm{Th}, 40 \mathrm{Al} \\
30 \mathrm{Th}, 200 \mathrm{Al} \\
60 \mathrm{Th}, 50 \mathrm{Al} \\
200 \mathrm{Th}\end{array}$ & $\begin{array}{l}\text { EB } \\
\text { EB } \\
\text { Arc } \\
\text { Arc } \\
\text { Arc } \\
\text { Arc }\end{array}$ & $\begin{array}{l}10.7 \\
15-23 \\
30.1 \\
32.0 \\
38.0 \\
37.8\end{array}$ & $\begin{array}{l}\text { GBS } \\
\mathrm{TF}+\mathrm{GBS} \\
\mathrm{DR} \\
\mathrm{DR} \\
\mathrm{DR} \\
\mathrm{DR}\end{array}$ & $\begin{array}{r}2.4 \\
- \\
3.8 \\
4.9 \\
5.1 \\
12.0\end{array}$ & $\begin{array}{c}2.2 \\
- \\
10.3 \\
10.8 \\
13.5 \\
25.2\end{array}$ & $\begin{array}{l}\text { GBS } \\
- \\
\text { GBS } \\
\text { GBS } \\
\text { GBS } \\
\text { TF + DR }\end{array}$ \\
\hline \multicolumn{8}{|c|}{ 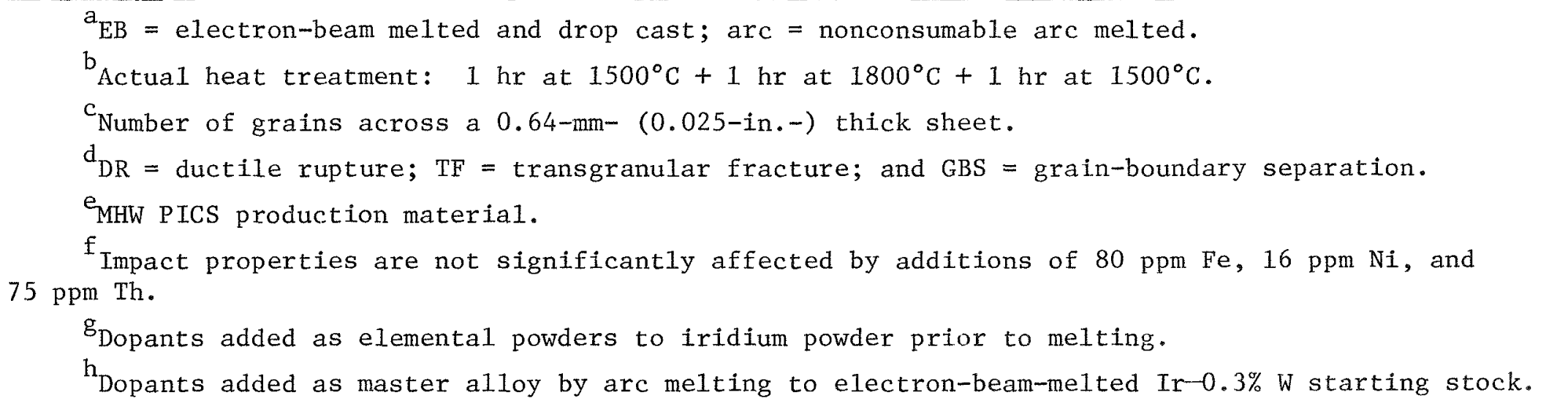 } \\
\hline
\end{tabular}




\subsection{Pt-Rh-W Alloys}

\subsubsection{Pt-3008 Scale-Up and Fabrication Development - M. M. Martin}

We are continuing scale-up and fabrication development of the Pt-3008 (Pt-30\% Rh-8\% W) alloy for isotope fuel containment and conversion system structural applications. Our objective is to develop and evaluate melting and fabrication processes leading to a process and material specification for commercial procurement of Pt-3008. We are also utilizing the material fabricated in this task to supply Pt-3008 sheet for testing and development in other program tasks. Progress during this reporting period includes completion of sheet production from E2X (second consumable vacuum-arcmelted ingot) ${ }^{7}$ and IMPI-1 (an induction-melted and poured slab casting). ${ }^{8}$ Table 1.7 indicates recipients and anticipated uses of the fabricated sheets. It also shows, for each starting rolling billet, the number, total weight, and average thickness of sheets from the fabrication. The identity of a rolling billet in Table 1.7 prefixes the identification of each sheet that was fabricated from that billet. Fabrication history of the sheets is as follows.

As reported previously, ${ }^{7,8}$ the rolling billets cut from E2X extruded bars, as well as the cropped IMPI-1 slab casting, were hot rolled at $1200^{\circ} \mathrm{C}$ and, in most cases, then warm rolled at either 1000 and $/$ or $1050^{\circ} \mathrm{C}$. Table 1.8 characterizes the rolling billets at this stage of fabrication in terms of last elevated rolling temperature, thickness, and heat-treating temperature in preparation for cold rolling. Sequential cold rolling and $1100^{\circ} \mathrm{C}$-vacuum-heat-treating operations, if required, then produced the sheet thickness in Table 1.7. For example, sheets from E2X-1A, $-2 \mathrm{~A}$, and $-1 B$ were cold rolled $50 \%$ in thickness and supplied without final heat treatment. The concluding history of sheets from IMPI-1, however, included cold rolling to a reduction in thickness of 42\%, heat treating $1 \mathrm{hr}$ at $1100^{\circ} \mathrm{C}$, further cold rolling of $50 \%$ to final thickness, and then a final stress-relieving heat treatment at $950^{\circ} \mathrm{C}$ in vacuum. All remaining sheets from $\mathrm{E} 2 \mathrm{X}-7 \mathrm{~B},-6 \mathrm{~B},-5 \mathrm{~B},-4 \mathrm{~B},-3 \mathrm{~B}$, and $-2 \mathrm{~B}$ billets in Table 1.8 were processed similarly to IMPI-1.

Fabrication of the nine E2X and one IMPI rolling billets yielded, respectively, 71.8 and 79.6 wt \% of their total starting weights as com-

pleted sheets. Trimming operations, which were sometimes required at the 
Table 1.7. Characterization and Distribution of Pt-3008 Sheets from E2X and IMPI-1 Heats

\begin{tabular}{|c|c|c|c|c|c|}
\hline \multirow{2}{*}{$\begin{array}{l}\text { Billet } \\
\text { Identity }\end{array}$} & \multicolumn{5}{|c|}{ Sheet Production } \\
\hline & Number & $\begin{array}{l}\text { Weight }{ }^{a} \\
\quad(g)\end{array}$ & $\begin{array}{l}\text { Thickness } \\
\text { mm(in.) }\end{array}$ & Recipient & Anticipated Use \\
\hline $\mathrm{E} 2 \mathrm{X}-1 \mathrm{~A}$ & 4 & 393 & $0.4826(0.019)$ & $\mathrm{ORNL}^{\mathrm{b}}$ & compatibility tests \\
\hline$-2 \mathrm{~A}$ & 2 & 374 & $0.4826(0.019)$ & ORNL & compatibility tests \\
\hline$-7 \mathrm{~B}$ & $\begin{array}{l}1 \\
1\end{array}$ & $\begin{array}{l}329 \\
356\end{array}$ & $\begin{array}{l}0.254(0.010) \\
0.2794(0.011)\end{array}$ & $\begin{array}{l}\mathrm{MBC}^{\mathrm{C}} \\
\mathrm{d}\end{array}$ & $\begin{array}{l}\text { vent fabrication } \\
\text { bellows fabrication }\end{array}$ \\
\hline$-6 B$ & 2 & 759 & $0.254(0.010)$ & MBC & bellows fabrication \\
\hline$-5 B$ & 2 & 624 & $0.254(0.010)$ & $\mathrm{BCL}$ & vent fabrication \\
\hline$-4 B$ & $\begin{array}{l}1 \\
1\end{array}$ & $\begin{array}{l}273 \\
199\end{array}$ & $\begin{array}{l}0.127(0.005) \\
0.254(0.010)\end{array}$ & $\begin{array}{l}\text { BCL } \\
\text { BCL }\end{array}$ & $\begin{array}{l}\text { vent fabrication } \\
\text { vent fabrication }\end{array}$ \\
\hline$-3 B$ & $\begin{array}{l}2 \\
2 \\
1\end{array}$ & $\begin{array}{r}275 \\
41 \\
392\end{array}$ & $\begin{array}{l}0.127(0.005) \\
0.254(0.010) \\
0.2794(0.011)\end{array}$ & $\begin{array}{l}\text { BCL } \\
\text { ORNL } \\
\text { MBC }\end{array}$ & $\begin{array}{l}\text { vent fabrication } \\
\text { weld test } \\
\text { bellows fabrication }\end{array}$ \\
\hline$-2 B$ & $\begin{array}{l}1 \\
1\end{array}$ & $\begin{array}{r}648 \\
39\end{array}$ & $\begin{array}{l}0.2794(0.011) \\
0.2794(0.011)\end{array}$ & $\begin{array}{l}\text { MBC } \\
\text { ORNL }\end{array}$ & $\begin{array}{l}\text { bellows fabrication } \\
\text { ultrasonic standard }\end{array}$ \\
\hline$-1 B$ & 1 & 180 & $0.4826(0.019)$ & ORNL & compatibility tests \\
\hline TOTAL E2X & WEIGHT & 4882 & & & \\
\hline IMPI-1 & $\begin{array}{l}1 \\
3 \\
1\end{array}$ & $\begin{array}{r}918 \\
2856 \\
146 \\
\end{array}$ & $\begin{array}{l}0.2794(0.011) \\
0.2794(0.011) \\
0.508(0.020)\end{array}$ & $\begin{array}{l}\text { MRC } \\
\text { ORNL } \\
\text { ORNL }\end{array}$ & $\begin{array}{l}\text { bellows fabrication } \\
\text { weld test; excess } \\
\text { mechanical property } \\
\text { tests }\end{array}$ \\
\hline
\end{tabular}

TOTAL IMPI WEIGHT 3920

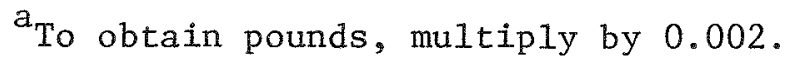

${ }^{b}$ Oak Ridge National Laboratory, Tennessee.

Battelle Columbus Laboratories, Ohio.

$\mathrm{d}_{\text {Metal }}$ Bellows Corporation, California.
} 
Table 1.8. Characterization of Billets before Cold Rolling

\begin{tabular}{|c|c|c|c|c|}
\hline $\begin{array}{l}\text { Billet } \\
\text { Identity }\end{array}$ & $\begin{array}{l}\text { Last Rol1ing } \\
\text { Temperature } \\
\left({ }^{\circ} \mathrm{C}\right)\end{array}$ & $\begin{array}{c}\text { Subsequent } \\
\text { Heat-Treating } \\
\text { Temperature } \\
\left({ }^{\circ} \mathrm{C}\right)\end{array}$ & $\begin{array}{l}\text { Thickness } \\
\text { [mm(in.)] }\end{array}$ & Remarks \\
\hline $\mathrm{E} 2 \mathrm{X}-1 \mathrm{~A}$ & 1000 & 1000 & $1.016(0.040)$ & $\begin{array}{l}\text { nose of incomplete } \\
\text { extrusion }\end{array}$ \\
\hline$-2 \mathrm{~A}$ & 1000 & 1000 & $1.016(0.040)$ & next section \\
\hline$-7 B$ & 1150 & 1150 & $1.524(0.060)$ & $\begin{array}{l}\text { nose of completed } \\
\text { extrusion }\end{array}$ \\
\hline$-6 B$ & 1200 & 1200 & $1.524(0.060)$ & next section \\
\hline$-5 B$ & 1050 & 1100 & $2.7178(0.107)$ & next section \\
\hline$-4 B$ & 1200 & 1200 & $1.27(0.050)$ & next section \\
\hline$-3 B$ & 1000 & 1100 & $2.159(0.085)$ & next section \\
\hline$-2 B$ & 1000 & 1000 & $1.016(0.040)$ & $\begin{array}{l}\text { tail of completed } \\
\text { extrusion }\end{array}$ \\
\hline IMPI-1 & 1050 & 1100 & $1.524(0.060)$ & \\
\hline
\end{tabular}

initiation and/or continuation of cold rolling, accounts for about 20 wt \% of the reduced material yield from an individual billet. Table 1.9 presents this result. That is, the material which was trimmed from E2X-1A, $-2 \mathrm{~A},-6 \mathrm{~B},-3 \mathrm{~B},-2 \mathrm{~B},-1 \mathrm{~B}$, and IMPI-I billets to obtain rectangular-shape pieces for cold rolling averaged about 20 wt \%. The relative starting weight of $E 2 X-1 B$, which was only about one quarter of the others, magnifies the material lost value from this billet.

Attempts to initiate cold rolling of $E 2 X-7 B,-5 B$, and $-4 B$ billets at a thickness of about $2.6 \mathrm{~mm}$ (0.10 in.), however, lowered the overall yield of material from about 80 to the 71.8 wt \%. As indicated in Table 1.9, two billets delaminated due to inhomogeneous deformation from the small cold reduction passes ( $E 2 X-5 B$ and $-7 B$ ) and one formed a severe edge crack $(E 2 X-4 B)$ when it was flattened to facilitate holding in a subsequent operation. These billets were repaired, but not without the significant loss of material. Their intermediate fabrication steps deviated from that of the other E2X billets. Fortuitously, the total delamination of E2X-5B occurred quite near to and uniformly along the midplane of the billet. 
Table 1.9. Yield of Fabricated Sheet from

E2X and IMPI-1 Rolling Billets

\begin{tabular}{|c|c|c|}
\hline $\begin{array}{l}\text { Billet } \\
\text { Identity }\end{array}$ & $\begin{array}{l}\text { Yield } \\
(w t \%)\end{array}$ & Remarks \\
\hline $\mathrm{E} 2 \mathrm{X}-1 \mathrm{~A}$ & 83 & \\
\hline$-2 \mathrm{~A}$ & 79 & \\
\hline$-7 B$ & 72 & $\begin{array}{l}\text { Limited delamination after initial } \\
4 \% \text { cold reduction }\end{array}$ \\
\hline$-6 B$ & 82 & \\
\hline$-5 B$ & 64 & $\begin{array}{l}\text { Delamination halved billet after } \\
\text { initial } 6 \% \text { cold reduction }\end{array}$ \\
\hline$-4 B$ & 48 & $\begin{array}{l}\text { Curved severely during warm roll- } \\
\text { ing and initial } 3 \% \text { cold reduction } \\
\text { attempts to flatten formed long } \\
\text { curving crack }\end{array}$ \\
\hline$-3 B$ & 80 & \\
\hline$-2 B$ & 79 & \\
\hline$-1 B$ & 74 & $\begin{array}{l}\text { Smallest billet; relative losses } \\
\text { magnified }\end{array}$ \\
\hline IMP I-1 & 80 & \\
\hline
\end{tabular}

The exposed surfaces therefore required only minor amounts of grinding to prepare them for cold rolling from a thickness of about $1.2 \mathrm{~mm}$ (0.05 in.). Unfortunately, the long curving crack in E2X-4B was located near the center of the billet. After removal of the crack from E2X-4B and also both delaminated ends from $E 2 X-7 B$, hot rolling, followed by heat treating at the rolling temperature, reduced these billets to the thickness shown in Table 1.8.

\subsubsection{Characterization of Pt-3008 Scale-Up Heats - J. R. Keiser}

The objective of this task is to characterize and determine the factors controlling the properties of Pt-3008, particularly the large change in ductility that generally occurs near room temperature and the ductility minimum that occurs around $1100^{\circ} \mathrm{C}$. In previous work, it has been found that the properties are affected by many factors including impurity concentrations and annealing and aging treatments. These prior investigations 
have been carried out over an extended time and, of necessity, on a variety of heats. In order to better relate some of these results, we are repeating the more significant, but are using one heat for all experiments. For this heat (the second scale-up heat, E2X) we will also obtain a complete chemical analysis, a measure of the grain size of certain specimens, and an Auger examination of the fracture surface of specimens displaying certain properties. From this we hope to advance our understanding of what part bulk impurities, the grain size, and/or the chemistry of the fracture surface play in controlling the mechanical properties of Pt-3008.

Results we have obtained include a complete chemical analysis of heat E2X and the tensile strength and elongation as a function of test temperature for specimens annealed and aged several ways. The results of the analysis are given in Table 1.10. Care should be exercised in evaluating this data because of previous experience in which tests of pieces from the same heat yielded greatly different results. Whether this is due to real compositional variations in the alloys or to lack of reproducibility of the analysis technique is not known.

The results of tensile tests of $\mathrm{Pt}-3008$ specimens annealed $1 \mathrm{hr}$ at $1200^{\circ} \mathrm{C}$ in vacuum are shown in Fig. 1.4. The low ductility at room temperature and the ductility minimum around $1100^{\circ} \mathrm{C}$ are apparent. Specimens which had received an aging treatment of $1000 \mathrm{hr}$ at $1100^{\circ} \mathrm{C}$ in a static vacuum following the $1-\mathrm{hr}-\mathrm{at}-1200^{\circ} \mathrm{C}$ standard anneal showed better ductility at room temperature and $1100^{\circ} \mathrm{C}$ but showed a large decrease in strength and ductility at $1316^{\circ} \mathrm{C}$ as can be seen in Fig. 1.5. This reduction in mechanical properties may be due to silicon contamination from the quartz encapsulation tube and this will possibly be investigated using Auger analysis of fracture surfaces. A $200-\mathrm{hr}-\mathrm{at}-1100^{\circ} \mathrm{C}$ aging treatment in hydrogen following the standard anneal had a significant effect only on the properties around the $1100^{\circ} \mathrm{C}$ ductility minimum as is shown in Fig. 1.6. Another set of specimens has been aged $1000 \mathrm{hr}$ at $1100^{\circ} \mathrm{C}$ in a dynamic vacuum and is currently being tested.

Metallography, scanning electron microscopy, and Auger spectroscopy are bding used when appropriate to examine the fracture surfaces of these specimens in an effort to explain the observed behavior. We are theorizing that the disappearance of the ductility minimum is a result of removal of an interstitial element, possibly $\mathrm{B}, 0$, or $\mathrm{C}$, by the aging treatments. We have not currently obtained any results to support this theory. 
Table 1.10. Chemical Analysis Results for Pt-3008 Second Scale-Up Heat ${ }^{a}$

\begin{tabular}{|c|c|c|}
\hline Element & $\underset{(\mathrm{ppm})}{\text { Sample }} 1$ & $\begin{array}{c}\text { Sample } \\
\text { (ppm) }\end{array}$ \\
\hline $\mathrm{Ag}$ & $<0.1$ & $<0.1$ \\
\hline $\mathrm{A} 1$ & 3 & 3 \\
\hline B & 1 & 1 \\
\hline $\mathrm{C}$ & 33 & 29 \\
\hline $\mathrm{Ca}$ & 0.3 & 0.1 \\
\hline $\mathrm{Cl}$ & 1 & 1 \\
\hline Co & 10 & 10 \\
\hline $\mathrm{Cr}$ & 30 & 30 \\
\hline $\mathrm{Cu}$ & 50 & 20 \\
\hline $\mathrm{Fe}$ & 150 & 150 \\
\hline $\mathrm{H}$ & 2 & 4 \\
\hline $\mathrm{HE}$ & 0.5 & 0.5 \\
\hline Ir & $\leq 30$ & $\leq 30$ \\
\hline $\mathrm{Mg}$ & 0.5 & $<0.5$ \\
\hline Mn & 3 & 3 \\
\hline MO & 100 & 50 \\
\hline $\mathrm{N}$ & 0.96 & 0.80 \\
\hline $\mathrm{Na}$ & $<0.1$ & $<0.1$ \\
\hline $\mathrm{Ni}$ & 50 & 50 \\
\hline $\mathrm{O}$ & 7 & 15 \\
\hline Os & 10 & 10 \\
\hline $\mathrm{P}$ & 1 & 1 \\
\hline $\mathrm{Pd}$ & 5 & 5 \\
\hline $\mathrm{Re}$ & 3 & 3 \\
\hline $\mathrm{Ru}$ & 5 & 5 \\
\hline $\mathrm{S}$ & 1 & 1 \\
\hline $\mathrm{si}$ & 3 & 10 \\
\hline $\mathrm{Sn}$ & 1 & 1 \\
\hline $\mathrm{Ta}$ & 10 & 10 \\
\hline Th & 20 & 5 \\
\hline $\mathrm{V}$ & 3 & 1 \\
\hline $\mathrm{Zn}$ & $<0.1$ & $<0.1$ \\
\hline $\mathrm{Zr}$ & 10 & 10 \\
\hline
\end{tabular}




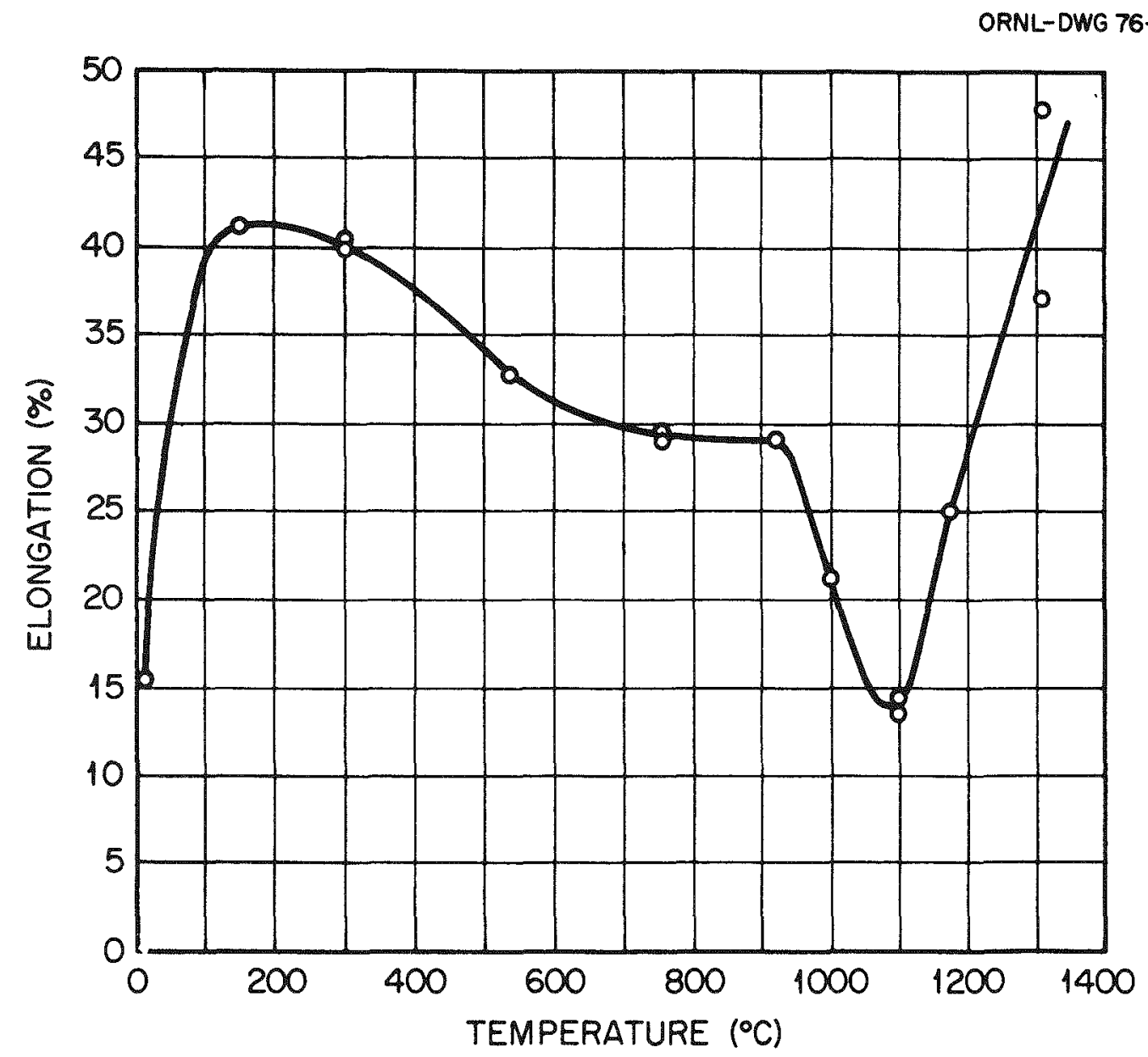

Fig. 1.4. Elongation vs Temperature of Pt-3008 Second Scale-Up Heat (Annealed $1 \mathrm{hr}$ at $1200^{\circ} \mathrm{C}$ ). 


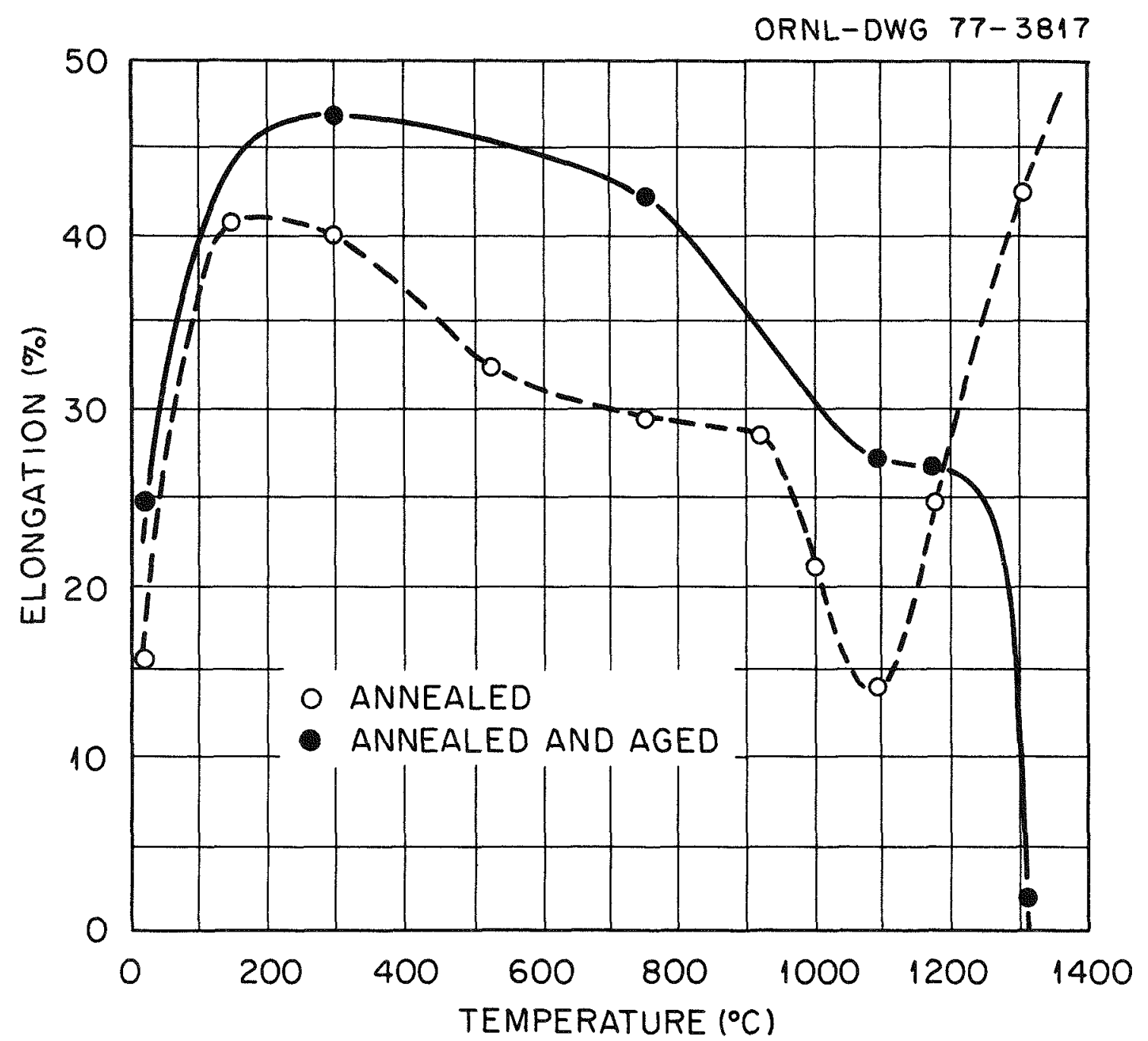

Fig. 1.5. Elongation vs Temperature of Pt-3008 Second Scale-Up Heat After a I-hr-at $-1200^{\circ} \mathrm{C}$ Anneal and After Aging of $1000 \mathrm{hr}$ at $1100^{\circ} \mathrm{C}$ in Static Vacuum. 


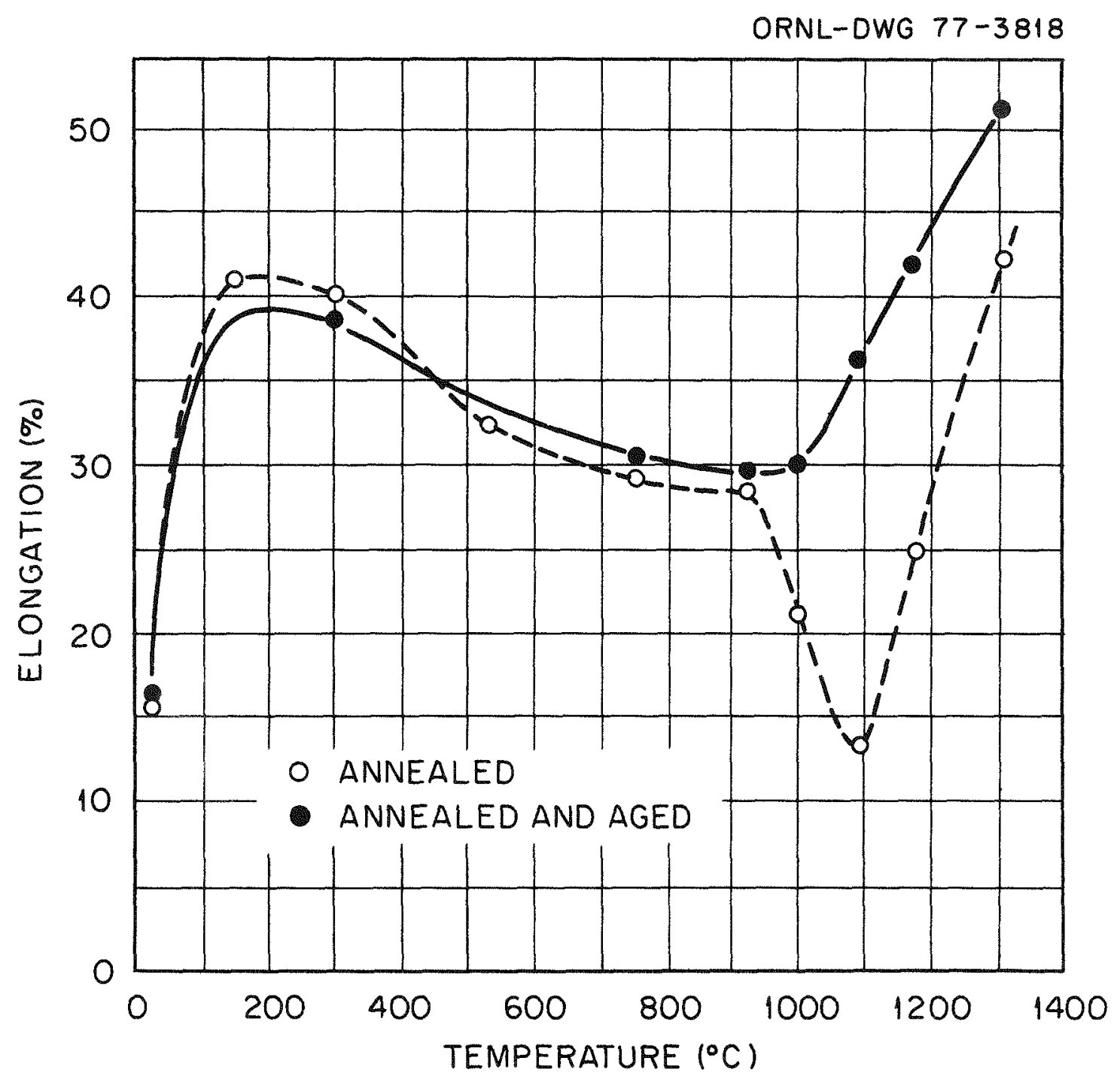

Fig. 1.6. Elongation vs Temperature of Pt-3008 Second Scale-Up Heat After a 1-hr-at $-1200^{\circ} \mathrm{C}$ Anneal and After Aging $200 \mathrm{hr}$ at $1100^{\circ} \mathrm{C}$ in $\mathrm{H}_{2}$. 
1.3.3 Welding of Pt-3008 Alloy - G. M. Goodwin and J. D. Hudson

Testing of weldments and base metal from the first scale-up heat (E1) is continuing. Base metal data from recent tests are summarized in Table 1.11, with previously reported tests for comparison. Specimens E1-22 through -24 were machined from sheet to determine the effects, if any, of the normal punching technique for specimen preparation. As is seen from the table, the data show no significant consistent effect of specimen preparation technique. Yield strength appears to be somewhat lower for machined sepcimens, but this property is subject to significant scatter. Ductility values are within the anticipated ranges. Additional machined specimens are being tested in the recrystallized condition to determine if there is any improvement in the ductility and scatter in data previously observed.

Table 1.11. Tensile Properties of $\mathrm{Pt}-3008^{\mathrm{a}}$

\begin{tabular}{|c|c|c|c|c|c|}
\hline \multirow{2}{*}{$\begin{array}{c}\text { Specimen } \\
\text { Designation }\end{array}$} & \multirow{2}{*}{$\begin{array}{l}\text { Specimen } \\
\text { Type }^{\mathrm{b}}\end{array}$} & \multirow{2}{*}{$\begin{array}{c}\text { Test } \\
\text { Temperature } \\
\left({ }^{\circ} \mathrm{C}\right)\end{array}$} & \multicolumn{2}{|c|}{ Strength, MPa(ksi) } & \multirow{2}{*}{$\begin{array}{c}\text { Total } \\
\text { Elongation } \\
(\%)\end{array}$} \\
\hline & & & $\begin{array}{c}0.2 \% \\
\text { Offset }\end{array}$ & U1timate & \\
\hline$E 1-22$ & $B-M$ & 20 & $910.1(132.0)$ & $1420.4(206.0)$ & 14.7 \\
\hline-23 & $B-M$ & 200 & $772.2(112.0)$ & $1332.1(193.2)$ & 13.0 \\
\hline-24 & $\mathrm{~B}-\mathrm{M}$ & 400 & $689.5(100.0)$ & $1180.4(171.2)$ & 10.0 \\
\hline-1 & B & 20 & $1149.4(166.7)$ & $1393.4(202.1)$ & 12.0 \\
\hline-2 & B & 20 & $1149.4(166.7)$ & $1393.5(202.1)$ & 12.0 \\
\hline-16 & B & 400 & - & $1221.0(177.0)$ & 11.8 \\
\hline-18 & B & 400 & $1149.1(166.7)$ & $1307.2(189.6)$ & 12.0 \\
\hline-19 & B & 760 & $948.1(137.5)$ & $999.8(145.0)$ & 8.5 \\
\hline
\end{tabular}

${ }^{a}$ Sheet, 0.56-mm- (0.022-in.-) thick, from heat E1, stress relieved $1 \mathrm{hr}$ at $850^{\circ} \mathrm{C}$.

$\mathrm{b}_{\mathrm{B}}=$ base metal specimens punched by usual technique; $\mathrm{B}-\mathrm{M}=$ base metal specimens machined. 


\subsection{Ruthenium and Rhodium Alloys}

H. Inouye

This task is directed toward the identification and the characterization of suitable cladding materials for isotopic fuels with lower density and/or lower cost than iridium- or platinum-base alloys.

\subsubsection{Rhodium-Ruthenium Alloys}

A series of rhodium-ruthenium alloys with the compositions 1isted in Table 1.12 have been or will be evaluated. The alloys containing less than approximately 50 wt \% Ru should be fcc and those alloys with greater than 60 wt \% Ru are expected to be $\mathrm{cph}^{9}$ To date, the alloys having the fcc . structure ( 45 wt \% Ru or less) appear to be fabricable while the cph alloys are not.

Table 1.13 lists the tensile properties of rhodium sheet prepared from an arc-melted and drop-cast ingot. The strength of this heat is considerably higher and the ductility lower than those reported for rod specimens ${ }^{10}$ (also listed in the table).

Table 1.12. Composition of Rhodium-Ruthenium Alloys

\begin{tabular}{ccl}
\hline $\begin{array}{c}\text { Alloy } \\
\text { Designation }\end{array}$ & $\begin{array}{c}\text { Ruthenium } \\
\text { Content } \\
(\text { wt \%) }\end{array}$ & Status \\
\hline $44-28$ & 0 & rolled to sheet \\
-32 & 9.8 & ingot cast \\
-09 & 20.0 & rolled to sheet \\
-29 & 34.6 & rolled to plate \\
-30 & 44.6 & rolled to plate \\
-31 & 64.5 & ingot cast \\
-08 & 80 & not fabricable \\
$-19,-20,-21$ & 100 & not fabricable \\
\hline
\end{tabular}


Table 1.13. Tensile Properties of Rhodium in Vacuum $^{\mathrm{a}}$

\begin{tabular}{|c|c|c|c|}
\hline \multicolumn{2}{|c|}{ Strength, MPa(ksi) } & \multirow[b]{2}{*}{$\underset{(\%)}{\text { Elongation }}$} & \multirow[b]{2}{*}{$\begin{array}{c}\text { Reduction } \\
\text { of Area } \\
(\%)\end{array}$} \\
\hline U1timate & $\begin{array}{c}0.2 \% \\
\text { Offset } \\
\text { Yield }\end{array}$ & & \\
\hline \multicolumn{4}{|c|}{$25^{\circ} \mathrm{C}$} \\
\hline $543.6(78.9)$ & $454.0(65.9)$ & 2.3 & 1.3 \\
\hline \multicolumn{4}{|c|}{$500^{\circ} \mathrm{C}$} \\
\hline $526.4(76.4)$ & $370.7(53.8)$ & 11.2 & 7.8 \\
\hline \multicolumn{4}{|c|}{$750^{\circ} \mathrm{C}$} \\
\hline $\begin{array}{l}406.5(59.0) \\
335.5(48.7)\end{array}$ & $\begin{array}{l}340.4(49.4) \\
106.1(15.4)\end{array}$ & $\begin{array}{l}15.2 \\
29\end{array}$ & $\begin{array}{l}15.7 \\
85(\operatorname{Ref} \cdot 10)\end{array}$ \\
\hline \multicolumn{4}{|c|}{$1000^{\circ} \mathrm{C}$} \\
\hline $\begin{array}{l}273.5(39.7) \\
117.1(17.0)\end{array}$ & $\begin{array}{c}226.0(32.8) \\
47.5(6.9)\end{array}$ & $\begin{array}{l}13.3 \\
61\end{array}$ & $\begin{array}{l}17.4 \\
100(\operatorname{Ref} .10)\end{array}$ \\
\hline
\end{tabular}

\subsection{References}

1. A. C. Schaffhauser, Isotopic Power Materials Development Quart. Progr. Rep. June 30, 1976, ORNL/TM-5569.

2. R. D. Baker, Pu-238 Fuel Development Program, the Space Nuclear Safety Program, and the Radioisotopic Terrestrial Safety Program Monthly Report for August 1976, CMB-2320, p. 21.

3. R. G. Donnelly, Isotopic Power Materials Ann. Prog. Rep. June 30, 1975, ORNL-TM-5116, p. 2.

4. A. C. Schaffhauser, Isotopic Power Materials Development Quart. Progr. Rep. Sept. 30, 1976, ORNL/TM-5810.

5. D. L. Coffey et a1., "Parametric Modification of Weld Microstructure in Iridium," WeZding J., 53:12 (December 1974).

6. A. C. Schaffhauser, Isotopic Power Materials Development Quart. Progr. Rep. June 30, 1976, ORNL/TM-5569, pp. 1-4. 
7. Ibid, p. 10 .

8. A. C. Schaffhauser, Isotopic Power Materials DeveZopment Quart. Progr. Rep. Sept. 30, 1976, ORNL/TM-5810.

9. E. M. Savitskii, V. P. Polyakova, N. R. Rosman, "Interaction of Ruthenium with P1atinum Group Metals," AlZ-Union Conference on the General Characteristics in the Construction of Structural Diagrams of Metalzic Systems, 5th, Moscow (1971), pp. 47-9.

10. R. W. Douglass, C. A. Krier, and R. I. Jaffee, High-Temperature Properties and AlZoying Behavior of the Refractory Pt-Group Metals, NP-10939 (August 1961). 
Blank 
2. PHYSICAL AND MECHANICAL METALLURGY OF HEAT-SOURCE CONTAINMENT MATERIALS*

\subsection{Introduction}

The high reliability in long-term unattended operation, high operating temperatures, and potentially severe accident conditions of isotope-fueled energy conversion systems require that materials for critical components be extensively tested and that the limitations on their use be defined. The objective of this program is to evaluate and determine the suitability and limitations of such materials. To accomplish this objective, we have concentrated our efforts on the evaluation of materials under the most severe potential accident conditions (e.g., high-velocity reentry and impact of an isotope heat source from space after long-term operation). The potential degradation of material properties from environmental and impurity effects is being evaluated along with studies on the mechanisms controlling the properties of materials of interest. In addition, special projects and consulting on materials problems for isotope-ıueled energy conversion systems are performed as requested by ERDA.

\subsection{Characterization of Impact Properties}

\subsubsection{Effect of Test Temperature on Impact Properties of Ir $-0.3 \% \mathrm{~W}$ Alloys -}

Tensile specimens of DOP-4 (30 ppm Th, 40 ppm Al), DOP-14 (200 ppm Th), and DOP-26 (60 ppm Th, $50 \mathrm{ppm} \mathrm{Al}$ ) alloys were heat treated 1 and $19 \mathrm{hr}$ at $1500^{\circ} \mathrm{C}$, then impact tested at $1050^{\circ} \mathrm{C}$ and $85 \mathrm{~m} / \mathrm{sec}(280 \mathrm{fps})$. The results are presented in Table 2.1 together with those of undoped WG specimens. Compared with the impact data obtained at $1350^{\circ} \mathrm{C}$, all the alloys had lower ductility at $1050^{\circ} \mathrm{C}$. However, the DOP-26 alloy remains ductile at $1050^{\circ} \mathrm{C}$ and has the best impact properties among the alloys. The impact ductility decreases with an increase in annealing time from 1 to $19 \mathrm{hr}$ at $1500^{\circ} \mathrm{C}$. This suggests that the impact properties of the alloys at $1050^{\circ} \mathrm{C}$ are also dependent on the heat treatment or grain size.

*Progress on work performed under Activity No. KJ 0601010 , 189a No. 01406 . 
Table 2.1. Tensile Impact Properties of Doped and Undoped Ir $-0.3 \% \mathrm{~W}$ Sheet Specimens Tested at $1050^{\circ} \mathrm{C}$ and $85 \mathrm{~m} / \mathrm{sec}(280 \mathrm{fps})$

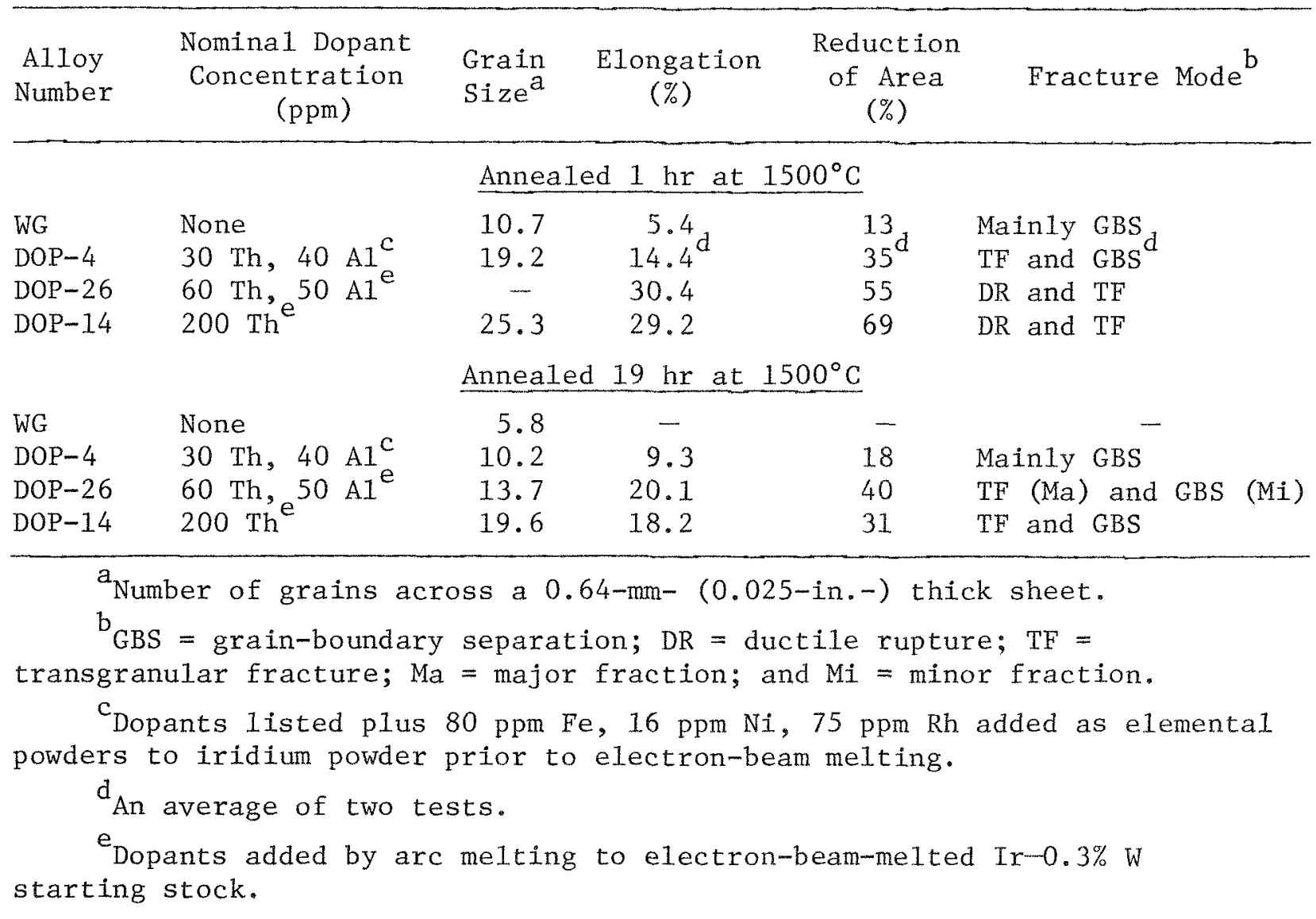




\subsubsection{Effect of Long-Term Heat Treatment at $1330^{\circ} \mathrm{C}$ on Impact Properties of Ir $0.3 \% \mathrm{~W}$ Alloys - C. T. Liu and D. E. Harasyn}

To study the effects of long-term heat treatment at the MHW clad temperature on the metallurgical and mechanical properties of Ir $-0.3 \% \mathrm{~W}$ alloys, DOP-4, -14 , and WG specimens were annealed at $1330^{\circ} \mathrm{C}$ for different periods then impacted at $1350^{\circ} \mathrm{C}$ and $85 \mathrm{~m} / \mathrm{sec}$ (280 fps). The impact results obtained for specimens annealed up to $6000 \mathrm{hr}$ are summarized in Table 2.2 and are plotted as a function of annealing time in Fig. 2.1. The grain size of the impact specimens was also measured and shown in Table 2.2. The impact ductility of the three alloys decreases with increasing annealing time; this decrease is apparently due to grain growth as indicated in Table 2.2. The DOP-14 alloy had $36.4 \%$ impact elongation while DOP-4 is estimated to have approximately $17 \%$ and WG approximately 5\% after a 5000-hr anneal. Thus, DOP-14 is much more resistant to degradation due to long-term heat treatment at $1330^{\circ} \mathrm{C}$.

\subsubsection{Impact Properties of Ir $-0.3 \%$ W Alloys Under Abnormal Conditions - C. T. Liu}

Under emergency cooling conditions, the fuel-clad temperature in the Brayton Isotope Power System (BIPS) may reach as high as $1660^{\circ} \mathrm{C}\left(\sim 3075^{\circ} \mathrm{F}\right)$ for a transition period of $60 \mathrm{hr}$. Since the impact properties of iridium alloys are sensitive to grain size, we are characterizing the impact behavior of thorium-doped $\mathrm{Ir}-0.3 \% \mathrm{~W}$ alloys at this severe condition.

Sheet specimens of DOP-2I (500 ppm Th) and DOP-14 (200 ppm Th) were heat treated in vacuum for $60 \mathrm{hr}$ at $1660^{\circ} \mathrm{C}$ then impacted at $1350^{\circ} \mathrm{C}$ and $85 \mathrm{~m} / \mathrm{sec}(280 \mathrm{fps})$. The impact results are presented in Table 2.3 together with the grain size measured from the shoulder of the impact specimens. Both alloys had more than $23 \%$ impact elongation, suggesting that they would survive the MHW/FSA-type impact test under this severe heat treatment condition. DOP-21 had better impact ductility then DOP-14 because of its finer grain structure, as indicated in Table 2.3. 
Table 2.2. Effect of Long-Term Anneal at $1330^{\circ} \mathrm{C}$ on the Impact Properties of Doped and Undoped Sheet Speciemns Tested at $85 \mathrm{~m} / \mathrm{sec}$ (280 fps) and $1350^{\circ} \mathrm{C}$

\begin{tabular}{|c|c|c|c|c|}
\hline Specimen & $\begin{array}{l}\text { Grain } \\
\text { Size }\end{array}$ & $\begin{array}{c}\text { Impact } \\
\text { Elongation } \\
(\%)\end{array}$ & $\begin{array}{c}\text { Reduction } \\
\text { of Area } \\
(\%)\end{array}$ & $\begin{array}{l}\text { Fracture } \\
\text { Mode }\end{array}$ \\
\hline \multicolumn{5}{|c|}{ 480-hr Anneal } \\
\hline $\begin{array}{l}W G^{c} \\
H D^{d}\end{array}$ & $\begin{array}{r}8.3 \\
15.2\end{array}$ & $\begin{array}{r}8.4 \\
26.5\end{array}$ & $\begin{array}{l}24 \\
90\end{array}$ & $\begin{array}{l}\text { Mainly GBS } \\
\text { DR }\end{array}$ \\
\hline \multicolumn{5}{|c|}{ 1000-hr Annea1 } \\
\hline $\begin{array}{l}W G^{C} \\
\mathrm{HD}^{\mathrm{d}} \\
\mathrm{DOP}-14^{\mathrm{e}}\end{array}$ & $\begin{array}{r}7.3 \\
11.0 \\
23.5\end{array}$ & $\begin{array}{r}8.6 \\
27.2 \\
42.8\end{array}$ & $\begin{array}{l}20 \\
88 \\
92\end{array}$ & $\begin{array}{l}\text { Mainly GBS } \\
\text { DR } \\
\text { DR }\end{array}$ \\
\hline \multicolumn{5}{|c|}{ 2000-hr Anneal } \\
\hline $\begin{array}{l}\text { WG } \\
H D\end{array}$ & $\begin{array}{l}4.7 \\
8.5\end{array}$ & $\begin{array}{r}7.8 \\
24.0\end{array}$ & $\begin{array}{l}19 \\
61\end{array}$ & $\begin{array}{l}\text { Mainly GBS } \\
\text { Mainly TF }\end{array}$ \\
\hline \multicolumn{5}{|c|}{ 3000-hr Anneal } \\
\hline DOP-14 & 18.1 & 38.3 & 86 & $\mathrm{DR}$ \\
\hline \multicolumn{5}{|c|}{ 4000-hr Anneal } \\
\hline $\begin{array}{l}\text { WG } \\
\mathrm{HD}\end{array}$ & $\begin{array}{l}4.4 \\
5.9\end{array}$ & $\begin{array}{r}6.4 \\
17.2\end{array}$ & $\begin{array}{l}14 \\
39\end{array}$ & $\begin{array}{l}\text { Mainly GBS } \\
\text { TF and GBS }\end{array}$ \\
\hline \multicolumn{5}{|c|}{ 5000-hr Anneal } \\
\hline DOP -14 & 15.5 & 36.5 & 84 & $\mathrm{DR}$ \\
\hline \multicolumn{5}{|c|}{ 6000-hr Anneal } \\
\hline $\mathrm{HD}$ & 5.2 & 16.2 & 34 & $\mathrm{TF}$ and $\mathrm{GBS}$ \\
\hline \multicolumn{5}{|c|}{$\begin{array}{l}{ }_{\text {Number of grains across a } 0.64-\mathrm{mm}(0.025-} \\
\text { thick sheet. } \\
{ }^{\mathrm{b}} \text { GBS }=\text { grain-boundary separation; TF }= \\
\text { transgranular fracture; DR = ductile rupture. } \\
{ }^{{ }} \text {Undoped } \mathrm{Ir}-0.3 \% \mathrm{~W} \text { alloy. } \\
{ }^{\mathrm{d}} \text { Ir-0.3\% W alloy doped with DOP-4 dopants. } \\
{ }^{\mathrm{e}} \text { Ir-0.3\% W alloy doped with } 200 \mathrm{ppm} \text { Th. }\end{array}$} \\
\hline
\end{tabular}




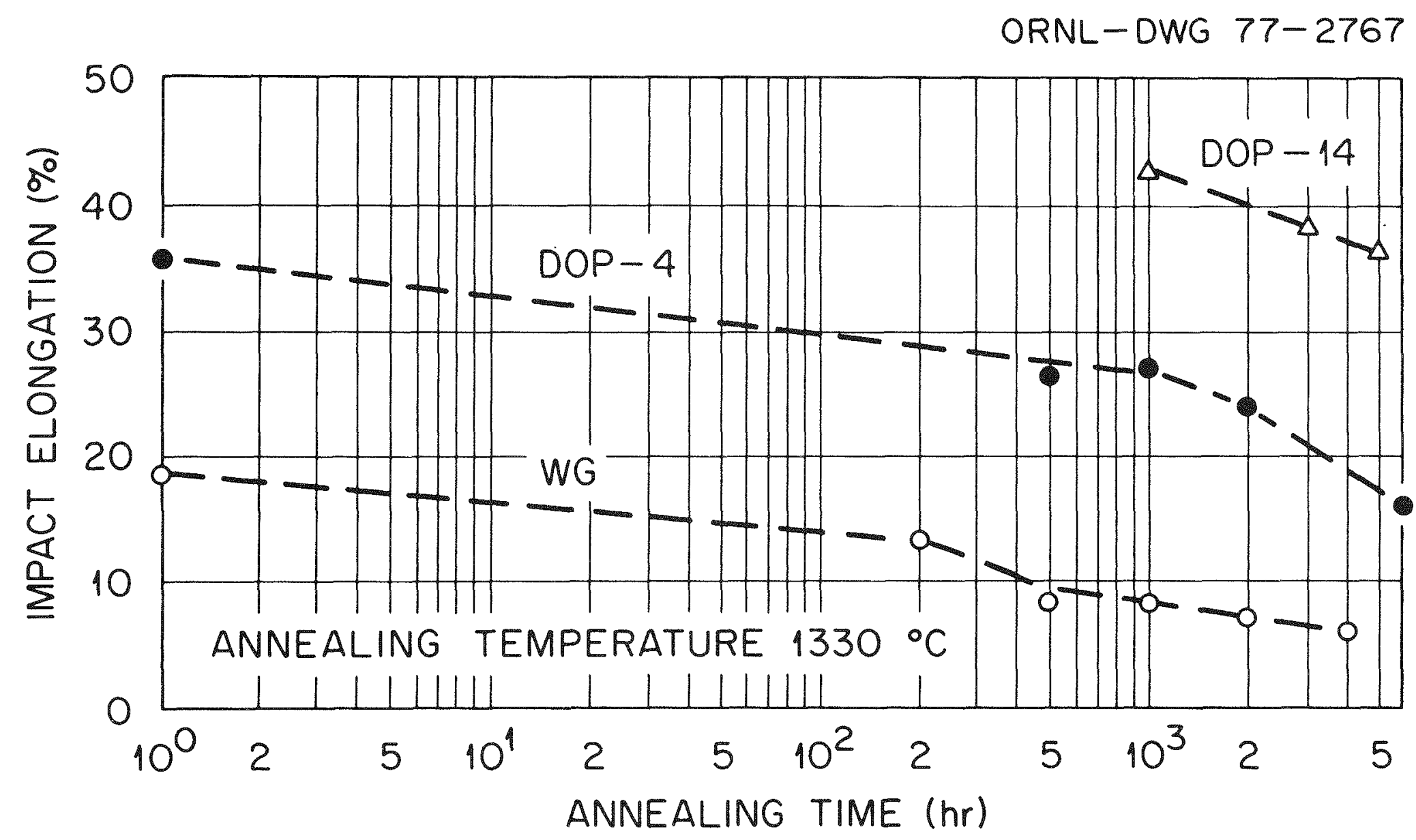

Fig. 2.1. Effect of Long-Term Annealing at $1330^{\circ} \mathrm{C}$ on Impact Elongation of WG, DOP-4, and DOP-14 Specimens. A11 specimens were impacted at $85 \mathrm{~m} / \mathrm{sec}(280 \mathrm{fps})$ and $1350^{\circ} \mathrm{C}$. 
Table 2.3. Tensile Impact Properties of $\mathrm{DOP}-14^{\mathrm{a}}$ and DOP $-21^{b}$ Alloys Heat Treated at $1660^{\circ} \mathrm{C}$ for $60 \mathrm{hr}$ and Tested at $85 \mathrm{~m} / \mathrm{sec}$ (280 fps) and $1350^{\circ} \mathrm{C}$

\begin{tabular}{|c|c|c|c|c|c|}
\hline Alloy & $\begin{array}{l}\text { Grain } \\
\text { Size }\end{array}$ & $\begin{array}{l}\text { Thorium } \\
\text { Content } \\
\text { (ppm) }\end{array}$ & $\underset{(\%)}{\text { Elongation }}$ & $\begin{array}{c}\text { Reduction } \\
\text { of Area } \\
(\%)\end{array}$ & $\begin{array}{l}\text { Fracture } \\
\text { Mode }^{\mathrm{d}}\end{array}$ \\
\hline DOP -14 & 8.6 & 200 & 23.3 & 53 & Mainly TF \\
\hline DOP-21 & 12.5 & 500 & 35.5 & 86 & $\mathrm{TF}$ and $\mathrm{DR}$ \\
\hline
\end{tabular}

\subsection{Environmenta1 and Impurity Effects}

\subsubsection{Air Oxidation of Iridium Alloys - C. T. Liu}

The Ir-0.3\% $\mathrm{W}$ alloys doped with active elements such as thorium may show internal oxidation when exposed to air in the post-impact temperature range and, thus, seriously affect their ductility. To characterize the air oxidation behavior of Ir-0.3\% W alloys, the tensile specimens of WG, DOP-4, $-22,-14$, and -21 (with their dopant concentrations 1isted in Table 2.4) are being exposed to still air at 670 and $870^{\circ} \mathrm{C}$ in tests scheduled to $5000 \mathrm{hr}$. At present, we have completed the 1000-hr exposure test. All the exposed specimens exhibited a thin, dark brown oxide coating on the surface. The specimens showed almost no weight change at $670^{\circ} \mathrm{C}$ but a weight loss at $870^{\circ} \mathrm{C}$.

The air-oxidized specimens were then tested in tension at the exposure temperature. The tensile results are shown in Table 2.4. All exposed specimens have $35-40 \%$ elongation at $670^{\circ} \mathrm{C}$ and $42-52 \%$ elongation at $870^{\circ} \mathrm{C}$, similar to the unexposed specimens. ${ }^{1}$ Also, the tensile and yield strengths are the same as the unexposed specimens. Thus, air exposure to $1000 \mathrm{hr}$ at 670 and $870^{\circ} \mathrm{C}$ does not degrade the tensile properties of doped and undoped Ir $-0.3 \% \mathrm{~W}$ alloys. 
Table 2.4. Tensile Properties ${ }^{a}$ of Undoped and Doped Ir-0.3\% W Sheet Specimens ${ }^{b}$ Exposed to Air for $1000 \mathrm{hr}$ at 670 and $870^{\circ} \mathrm{C}$

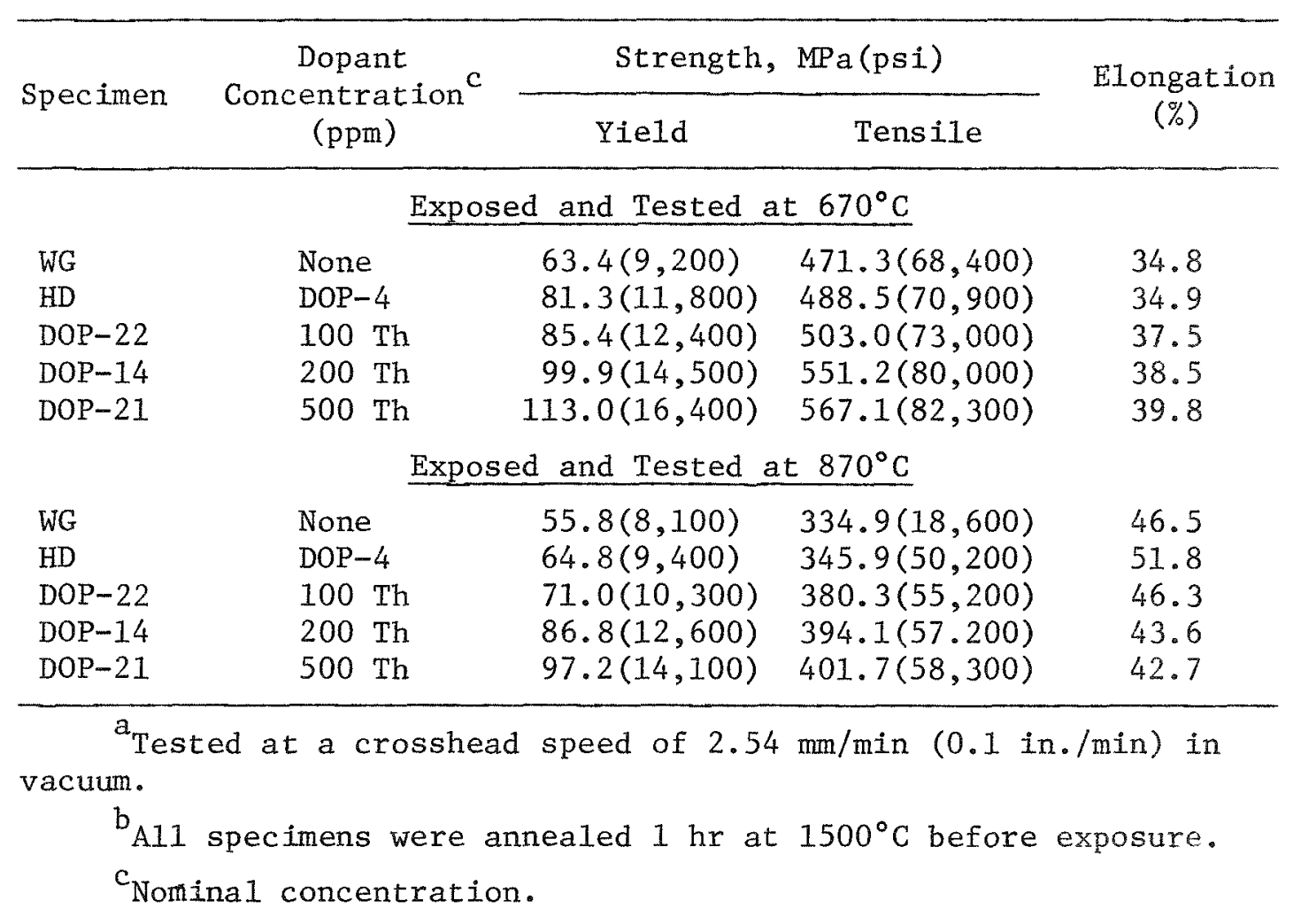

\subsubsection{Pt-3008/Graphite Compatibility - J. R. Keiser}

One proposed use of $\mathrm{Pt}-3008$ is for encapsulation of ${ }^{238} \mathrm{PuO}_{2}$ isotope fuel. To be considered for this application, the alloy must demonstrate an ability to survive a launch pad accident in which a fuel capsule inside a graphite impact shell would fall onto a piece of burning solid propellant rocket fuel. Calculations have indicated the exposure conditions could be as severe as $1800^{\circ} \mathrm{C}$ for $5 \mathrm{~min}$. The concern about using $\mathrm{Pt}-3008$ for this application is the eutectic reaction which occurs between $\mathrm{Pt}-3008$ and graphite below $1850^{\circ} \mathrm{C}$. In order to determine the suitability of Pt-3008 for use in fuel encapsulation, we have taken pieces of graphite and the a1loy, put them in contact and held them for $5 \mathrm{~min}$ at an elevated temperature. We have exposed specimens at temperatures of $1750,1800,1850,1900$, and $1950^{\circ} \mathrm{C}$. Results of metallographic examinations, shown in Fig. 2.2, indicate significant but noncatastrophic reaction between $\mathrm{Pt}-3008$ and 
$Y-\$ 44740$
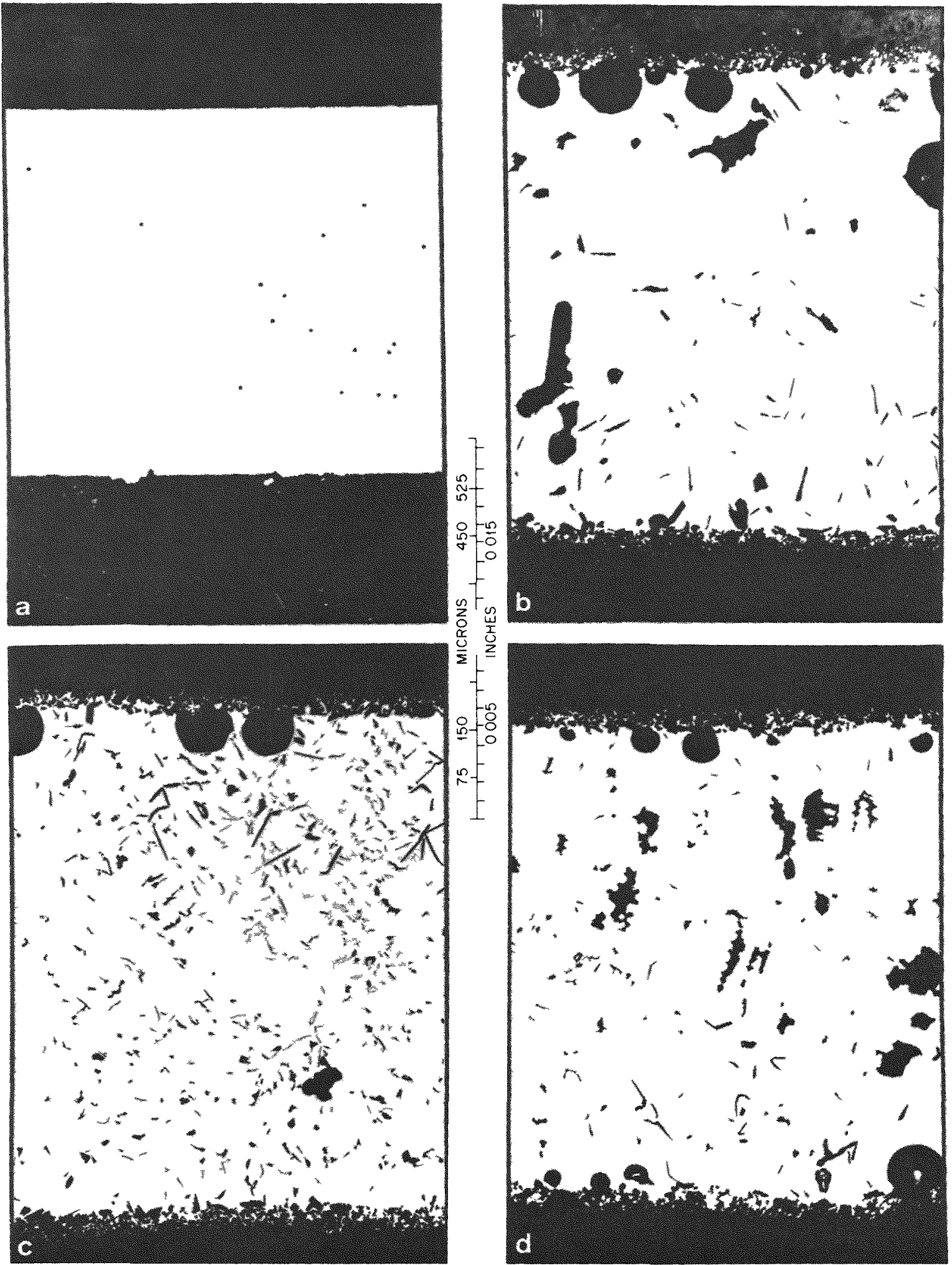

Fig. 2.2. Pt-3008 in Contact with POCO AXF-Q1 Graphite for 5 Min in Vacuum at (a) 1750 , (b) 1800 , (c) 1900 , and (d) $1950^{\circ} \mathrm{C}$. 
graphite. For specimens tested below $1800^{\circ} \mathrm{C}$, the microstructure shows spheres of graphite in the Pt-3008, while the microstructures of specimens tested at $1800^{\circ} \mathrm{C}$ and above show platelets of graphite indicative of localized eutectic reaction. Although there is a large amount of graphite in the higher-temperature specimens, Pt-3008 may be capable of providing the fuel containment required for this maximum credible accident condition.

A test has also been conducted to determine if a layer of iridium between the Pt-3008 and the graphite would prevent reaction, but, as can be seen in Fig. 2.3, the iridium did not significantly affect the results. Additional tests are being performed with Pt-3008 tensile specimens exposed to graphite at $1900^{\circ} \mathrm{C}$ then tested to determine the effect of exposure on mechanical properties.

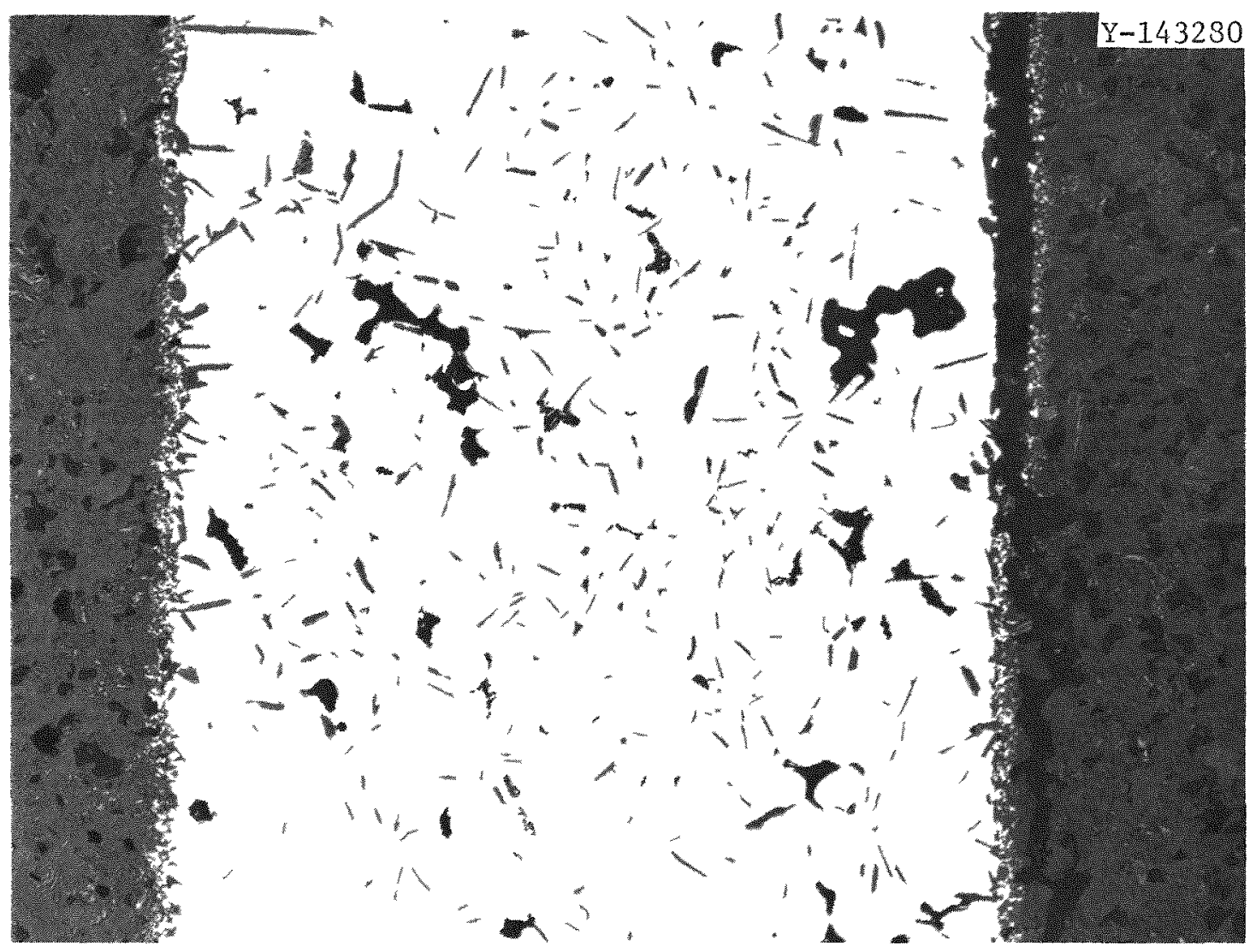

Fig. 2.3. Pt-3008 with 5-Mil Ir $0.3 \% \mathrm{~W}$ Foil on Both Sides Contacting Same Graphite for 5 Min in Vacuum at $1900^{\circ} \mathrm{C}$. 


\subsection{Microanalysis Studies}

C. L. White, L. Heatherly, Jr., and R. E. Clausing

\subsubsection{Analysis of Iridium Cladding from Impacted Simulant Fuel Sphere Assemblies}

2.4.1.1 Introduction. - Preliminary examination of the iridium Post Impact Containment She11 (PICS) used in simulant fuel sphere impacts MHT-103 and -104 indicates that the impact performance of these PICS is significantly worse than that for PICS in MHT-90, -91 , and $-92 .{ }^{2}, 3$ While MHT-90, -91, and -92 survived impact without breaches in the cladding, MHT-103 cracked along the closure weld and on the inside of the impact face (fingerprint cracking), and MHT-104 had a 19.05-mm- (3/4-in.-) diam piece broken out of the impact face due to fingerprint cracking. Because the failure mode during impact involved intergranular separation, a study of the grain boundary chemistries of these alloys, using Auger spectroscopy, has been initiated. Table 2.5 summarizes the samples examined up to this point. The results on samples from MHT-103 and -104 have been reported previously ${ }^{4}$ but are included here for comparison with results from MHT-90, -91 , and -92 .

Samples from MHT-90, -91 , and -92 were prepared for analysis in a similar manner to samples from MHT-103 and 104; however, the following difference should be noted. Unlike samples from MHT-103 and -104, samples from MHT-90, -91 , and -92 were baked out $\left(\sim 200^{\circ} \mathrm{C}\right)$ in the vacuum transfer lock prior to being placed in the AES-UHV system for Auger analysis. This procedure results in less oxygen contamination of the fracture surfaces, hence less attenuation of the thorium signaled as a function of time. ${ }^{5}$

\subsubsection{Analysis and Results. - Samples 760135 and 760136 (MHT-91)}

were the first of the samples in Table 2.5 to be analyzed. Figure 2.4 shows the Auger spectrum from the center of the fracture surface of sample 760135. This spectrum shows carbon and oxygen peaks that are somewhat larger than normal, with thorium intensity at approximately normal levels for DOP-4-type a11oys. 
Table 2.5. Description of Samples Analyzed Using Auger Electron Spectroscopy

\begin{tabular}{|c|c|c|c|c|}
\hline $\begin{array}{l}\text { Simulant } \\
\text { Fuel Sphere } \\
\text { Assembly }\end{array}$ & $\begin{array}{l}\text { Fue1 } \\
\text { Cladding } \\
\text { Heat }\end{array}$ & $\begin{array}{c}\text { Performance in Simulant } \\
\text { Fuel Impact Test }\end{array}$ & $\begin{array}{l}\text { Auger } \\
\text { Sample } \\
\text { Number }\end{array}$ & Location \\
\hline MHT -90 & $\begin{array}{l}\mathrm{DOP}-4-3 \\
\text { and } \\
\mathrm{DOP}-4-4\end{array}$ & $\begin{array}{l}\text { Microcracking in regions } \\
\text { having dye penetrant indi- } \\
\text { cations prior to impact }\end{array}$ & $\begin{array}{l}760157 \\
760158\end{array}$ & $\begin{array}{l}\text { Weld } \\
\text { Sheet }\end{array}$ \\
\hline MHT-91 & DOP $-4-2$ & $\begin{array}{l}\text { No cracks observed at } 30 \times \\
\text { or by dye penetrant }\end{array}$ & $\begin{array}{l}760136 \\
760135\end{array}$ & $\begin{array}{l}\text { Weld } \\
\text { Sheet }\end{array}$ \\
\hline MHT-92 & DOP-4-4 & No breach observed at $30 \times$ & $\begin{array}{l}760184 \\
760185\end{array}$ & $\begin{array}{l}\text { Weld } \\
\text { Sheet }\end{array}$ \\
\hline MHT-103 & & $\begin{array}{l}\text { 1-in. crack along closure } \\
\text { weld-fingerprint cracking } \\
\text { on inside of impact fact } \\
\text { penetrating } 50 \% \text { of the wall } \\
\text { thickness }\end{array}$ & $\begin{array}{l}760131 \\
760130\end{array}$ & $\begin{array}{l}\text { Weld } \\
\text { Sheet }\end{array}$ \\
\hline MHT-104 & & $\begin{array}{l}\text { 3/4-in. piece broken out of } \\
\text { impact face due to finger- } \\
\text { print cracking }\end{array}$ & $\begin{array}{l}760133 \\
760132\end{array}$ & $\begin{array}{l}\text { Weld } \\
\text { Sheet }\end{array}$ \\
\hline
\end{tabular}




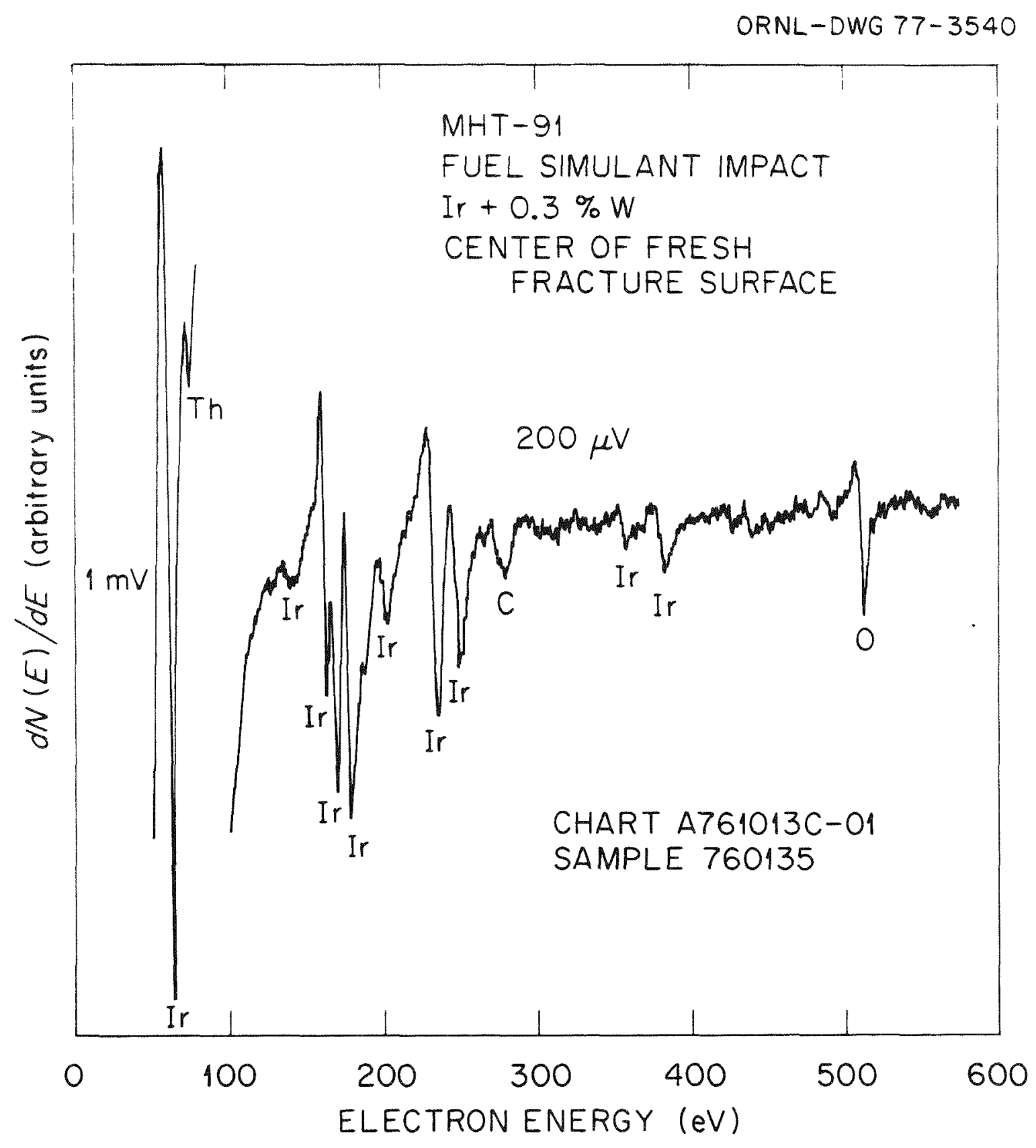

Fig. 2.4. An Auger Spectrum from the Fresh Fracture Surface of Sample 760135 (MHT-91, w/o weld). This spectrum was taken while rastering the primary electron beam over a small area in the center of the fracture surface. 
Figure 2.5 shows the Auger spectrum from near the inner edge* of the fracture surface and sample 760135. Large concentrations of S, P, C, and 0 are indicated in this spectrum and the $67-\mathrm{eV}$ Th peak is almost undetectable.

In order to obtain a semi-quantitative comparison between spectra, a ratio of peak intensities can be used. The ratio of $I(P, 120 \mathrm{eV})$ to $\mathrm{I}(\mathrm{Ir}, 229 \mathrm{eV})$ in Fig. 2.5 is approximately 0.82 . This number is approximately proportional to $\mathrm{X}_{\mathrm{P}}$ (the atom fraction of $\mathrm{P}$ ) divided by $\mathrm{X}_{\mathrm{Ir}}$ (the atom fraction of $\mathrm{Ir})$. Estimates of the ratio $\mathrm{X}_{\mathrm{P}} / \mathrm{X}_{\mathrm{Ir}}$ can be obtained by multiplying the peak height ratio by $S_{\text {Ir }}^{\mathrm{Ag}} / \mathrm{S}_{\mathrm{P}}^{\mathrm{Ag}}$ where $\mathrm{S}_{\text {Ir }}^{\mathrm{Ag}}$ and $\mathrm{S}_{\mathrm{P}}^{\mathrm{Ag}}$ are the sensitivities of Ir and $P$ with respect to a Ag standard. Approximate values of sensitivity factors for some of the Auger peaks observed in Fig. 2.5 are listed in Table 2.6. These sensitivity factors are estimated from standard spectra of pure elements and compounds in the Handbook of Auger Electron Spectroscopy. ${ }^{6}$ The use of sensitivity factors in the manner outlined above does not account for possible differences between the analyzer used to obtain the experimental data and the one used to generate the handbook spectra. Matrix, chemical, and distribution effects are also ignored using the procedure. Because of these complications and because relative differences in composition are of primary interest, the data from the Auger analysis of the samples in Table 2.5 will be presented as peak height ratios. Approximate atom fraction ratios could be estimated from the peak height ratios using the data in Table 2.6, however, those values should be used with considerable caution.

It should be pointed out that the measurement of $I(S, 152 \mathrm{eV})$ is hampered by the presence of the 154-eV Ir peak. In the case of Fig. 2.5, where $I(S, 152 \mathrm{eV})$ is much larger than $I(\operatorname{Ir}, 154 \mathrm{eV})$, it is reasonable, for our purposes, to ignore the effect of the $154-\mathrm{eV}$ Ir peak. For spectra where $I(S, 150 \mathrm{eV}$ ) is smaller, or not much larger than I(Ir, $154 \mathrm{eV}$ ), interference between the two peaks makes measurement of $I(S, 152 \mathrm{eV})$ subject to considerable

\footnotetext{
*The "inner" edge of the fracture surface will refer to the edge of the fracture surface nearest the concave surface of the cladding. Using this definition, the inner edge of the fracture surface was nearest to the $\mathrm{ThO}_{2}$ fuel simulant, and the outer edge of the fracture surface was nearest to the graphite impact shel1 (GIS).
} 
ORNL-DWG 77-3539

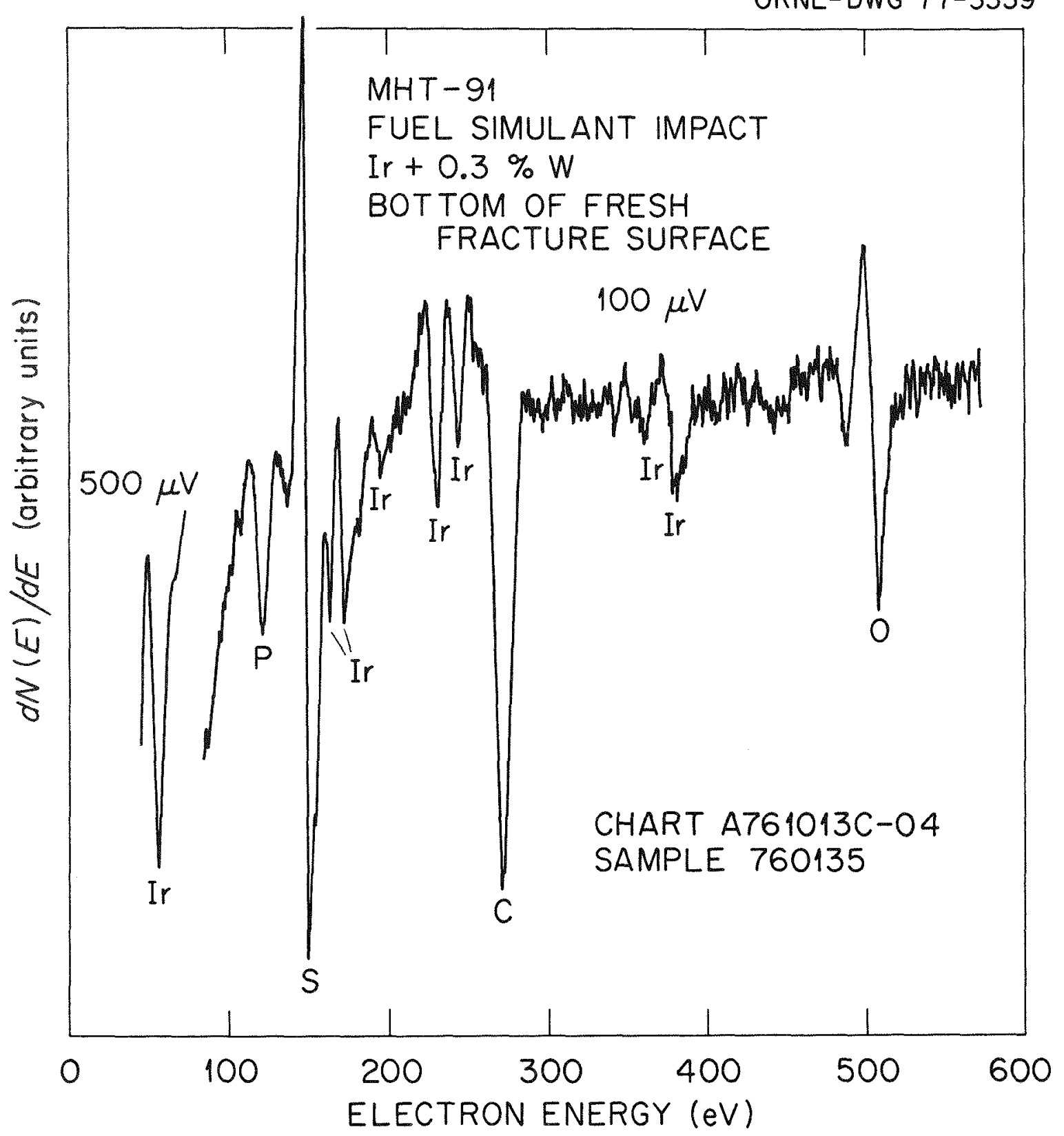

Fig. 2.5. An Auger Spectrum from the Fresh Fracture Surface of Sample 760135 (MHT-91, w/o weld). This spectrum was taken while the primary electron beam was located on a spot near the inner edge of the fracture surface. 
Table 2.6. Sensitivity Factors ${ }^{\mathrm{a}}$

for Selected Auger Peaks

\begin{tabular}{lcc}
\hline Element & $\begin{array}{c}\text { Peak Energy } \\
(\mathrm{eV})\end{array}$ & $\begin{array}{c}\text { Sensitivity Factor } \\
\text { (relative to } 351 \mathrm{eV} \mathrm{Ag})\end{array}$ \\
\hline Ir & 54 & 0.30 \\
Ir & 154 & 0.047 \\
Ir & 229 & 0.049 \\
Th & 67 & 0.35 \\
P & 120 & 0.46 \\
S & 152 & 0.76 \\
C & 272 & 0.15 \\
0 & 510 & $1.02^{b}$ \\
\hline
\end{tabular}

$\mathrm{a}_{\text {These sensitivities are calculated from }}$ standard Auger spectra of elements and compounds found in the Handbook of Auger Electron Spectroscopy. ${ }^{6}$ Except where indicated, spectra taken with a $5-\mathrm{keV}$ primary beam were used.

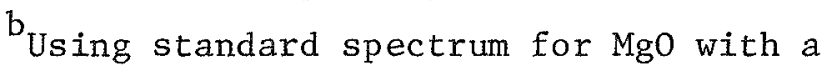
3-keV primary beam.

error. The values of $\mathrm{I}(\mathrm{S}, 152 \mathrm{eV})$ used in this study have been measured from the extreme positive deviation of the combined 152-eV S and 154-eV Ir peaks to the negative deviation of the 152-eV S peak.

The location of the spots where Auger spectra were taken from the fracture surface of sample 760135 are indicated in Fig. 2.6. The peak height ratios for elements indicated in these spectra are given in Table 2.7 along with the ratio:

$x / t$

where

$x=$ the distance from the inner edge of the fracture surface to the spot analyzed, and

$t=$ the distance from the inner edge to the outer edge of the fracture surface on the sample current image.

The data in Table 2.7 indicate contamination of the grain boundaries near the bottom edge of the fracture surface with $P$ and $S$. Larger than normal concentrations of $\mathrm{C}$ and $\mathrm{O}$ are also indicated in all spectra, with 


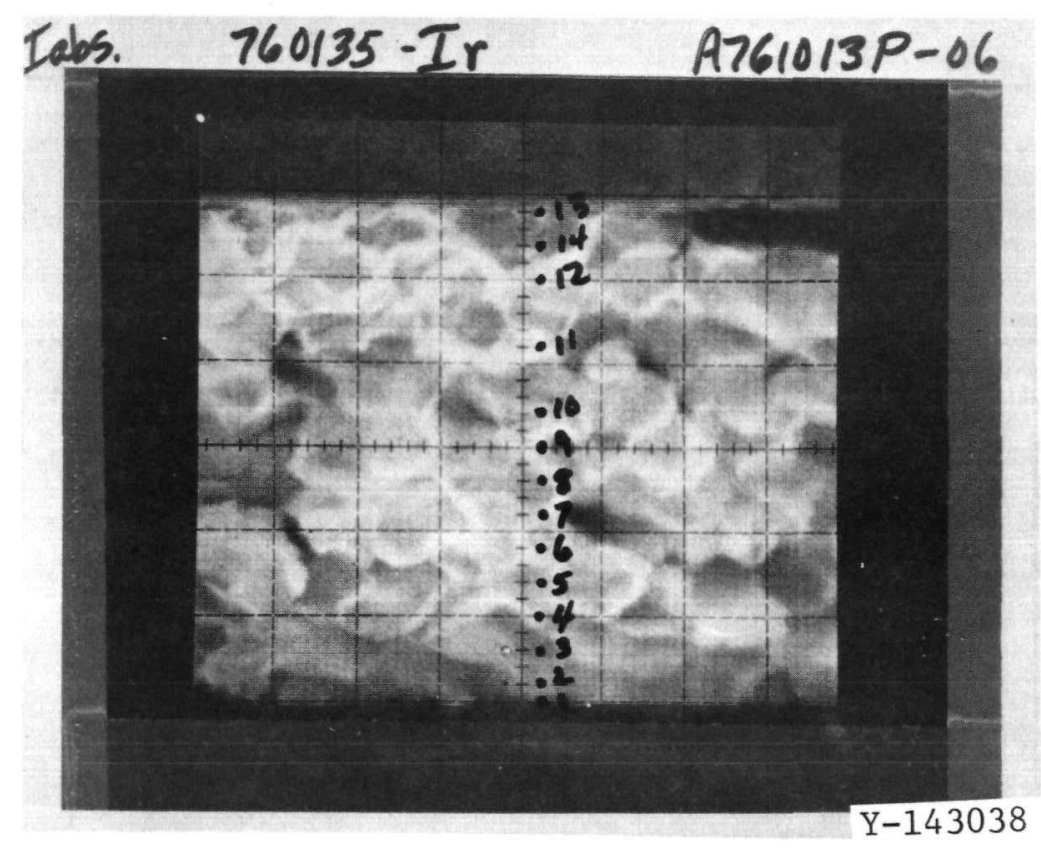

Fig. 2.6. A Sample Current Image of the Fracture Surface of Sample 760135, Showing the Spots Where Auger Spectra Were Taken. 
Table 2.7. Summary of Auger Results for Sample 760135 (MHT-91, w/o We1d)

\begin{tabular}{|c|c|c|c|c|c|c|c|c|}
\hline \multicolumn{2}{|c|}{ Chart } & Spot & $x / t$ & $\frac{I(\mathrm{Th}, 67 \mathrm{eV})}{I(\mathrm{Ir}, 54 \mathrm{eV})}$ & $\frac{\mathrm{I}(\mathrm{P}, 120 \mathrm{eV})}{\mathrm{I}(\mathrm{Ir}, 229 \mathrm{eV})}$ & $\frac{\mathrm{I}(\mathrm{S}, 152 \mathrm{eV})}{\mathrm{I}(\mathrm{Ir}, 229 \mathrm{eV})}$ & $\frac{I(C, 272 \mathrm{eV})}{I(\mathrm{Ir}, 229 \mathrm{eV})}$ & $\frac{I(0,510 \mathrm{eV})}{I(\operatorname{Ir}, 229 \mathrm{eV})}$ \\
\hline A761013 & $c-03^{a}$ & 1 & 0 & 0 & 0.85 & 5.65 & 8.15 & 3.90 \\
\hline & $-04^{a}$ & 2 & 0.04 & 0 & 0.82 & 4.66 & 2.92 & 1.80 \\
\hline & $-05^{a}$ & 3 & 0.10 & 0.03 & 0.57 & 3.02 & 0.98 & 0.84 \\
\hline & $-06^{a}$ & 4 & 0.17 & 0.08 & 0.56 & 3.02 & 0.67 & 1.02 \\
\hline & $-07^{\mathrm{a}}$ & 5 & 0.24 & 0.06 & 0 & 2.45 & 0.86 & 0.57 \\
\hline & $-08^{a}$ & 6 & 0.30 & 0.06 & 0 & 0.90 & 0.62 & 0.40 \\
\hline & $-09^{a}$ & 7 & 0.37 & 0.07 & 0 & 1.17 & 0.57 & 0.43 \\
\hline & $-10^{a}$ & 8 & 0.44 & 0.04 & 0 & 0.50 & 0.40 & 0.29 \\
\hline & $-11^{a}$ & 9 & 0.50 & 0.06 & 0 & 0.70 & 0.43 & 0.26 \\
\hline & $-12^{\mathrm{a}}$ & 10 & 0.58 & 0.02 & 0 & 0.54 & 0.46 & 0.25 \\
\hline & $-13^{a}$ & 11 & 0.70 & 0.02 & 0 & 1.08 & 0.74 & 0.47 \\
\hline & $-14^{\mathrm{a}}$ & 12 & 0.84 & 0.04 & 0 & 1.35 & 0.81 & 0.34 \\
\hline & $-15^{a}$ & 13 & 0.98 & 0 & 0 & 1.31 & 2.21 & 0.52 \\
\hline & $-16^{a}$ & 14 & 0.91 & 0 & 0 & 1.03 & 0.79 & 0.42 \\
\hline A761020 & $c-03^{b}$ & 3 & 0.10 & 0 & 0.04 & 0 & 0.33 & 0.21 \\
\hline
\end{tabular}

a Spectra taken on fresh fracture surface.

${ }^{b}$ Sputtered for $2 \mathrm{~min}$. Sputtering conditions were set to remove the equivalent of one atom layer of $\mathrm{Ta}_{2} \mathrm{O}_{5}$ per minute of sputtering time. 
the largest peak height ratios near the inner edge of the fracture surface. The Th levels indicated in Table 2.7 are somewhat lower than those normally observed in DOP-4-type Ir $-0.3 \% \mathrm{~W}$ alloys; however, the presence of the 0 may be masking the Th peak. Inert ion sputtering experiments indicated that the $\mathrm{P}$ and $\mathrm{S}$ contamination was confined to within a few atom layers of the grain boundary.

The results of Auger analysis of sample 760136 are summarized in Table 2.8. The locations of the spots indicated in Table 2.8 are shown in Fig. 2.7. The inner edge of the fracture surface was contaminated with $P$, and slight indications of $\mathrm{S}$ were indicated at isolated locations near the outer and inner edges of the fracture surface. The level of Th was generally somewhat higher than for 760135; however, there was much variation from spot to spot.

Because of the high S, C, and 0 levels observed on sample 760135 , samples from MHT-90 and -92 were acid cleaned prior to ultrasonic cleaning in alcohol in an effort to remove foreign material that might be embedded in pre-existing cracks.

The results of Auger analysis on samples from MHT-90 (760158 and 760157) are summaried in Tables 2.9 and 2.10, respectively. The locations of the spots where spectra are taken are shown in Figs. 2.8 and 2.9. Both of these samples had indications of $P$ contamination at various locations near the inner edge of the fracture surface; however, the contamination did not appear to be continuous since other spots near the inner edge showed little or no evidence of $\mathrm{P}$ contamination. The Th-to-Ir peak height ratios in Tables 2.9 and 2.10 range from nearly twice the average values for DOP-4type $\operatorname{Ir}-0.3 \% \mathrm{~W}$ down to very small values. Neither of the samples from MHT-90 had any indication of $\mathrm{S}$ contamination.

The data for samples from MHT-92 are summarized in Tables 2.11 and 2.12. The location of the spots where spectra were taken are indicated in Figs. 2.10 and 2.11. These results follow much the same pattern as those for MHT-91, with indications of $\mathrm{P}$ contamination near the inner edge of the fracture surface, and isolated spots of high $S$ near the outer and inner edges.

2.4.1.3 Summary and Conclusions. - The data concerning the distribution of thorium and phosphorus on the fracture surfaces is summarized in 
Table 2.8. Summary of Auger Results for Sample 760136 (MHT-91, with Weld)

\begin{tabular}{|c|c|c|c|c|c|c|c|c|}
\hline \multicolumn{2}{|c|}{ Chart } & Spot & $x / t$ & $\begin{array}{l}\mathrm{I}(\mathrm{Th}, 67 \mathrm{eV}) \\
\mathrm{I}(\mathrm{Ir}, 54 \mathrm{eV})\end{array}$ & 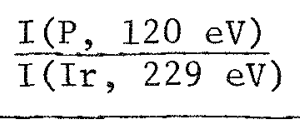 & \multirow[t]{2}{*}{$\frac{\mathrm{I}(\mathrm{S}, 152 \mathrm{eV})}{\mathrm{I}(\mathrm{Ir}, 229 \mathrm{eV})}$} & $\frac{\mathrm{I}(\mathrm{C}, 272 \mathrm{eV})}{\mathrm{I}(\mathrm{Ir}, 229 \mathrm{eV})}$ & $\frac{I(0,510 \mathrm{eV})}{I(\mathrm{Ir}, 229 \mathrm{eV})}$ \\
\hline \multirow[t]{4}{*}{ A761014 } & $C-07^{a}$ & 1 & 0 & 0 & 1.64 & & 0.59 & 0.62 \\
\hline & $-09^{a}$ & 3 & 0.12 & 0.08 & 0.96 & 0.29 & 0.58 & 0.40 \\
\hline & $-10^{a}$ & 4 & 0.18 & 0.08 & 0.75 & 0.12 & 0.37 & 0.28 \\
\hline & $-12^{a}$ & 6 & 0.30 & 0.03 & 0 & 0 & 0.30 & 0.24 \\
\hline \multirow[t]{3}{*}{ A761020 } & $C-01^{a}$ & 7 & 0.50 & 0.01 & 0 & 0 & 0.52 & 0 \\
\hline & $-02^{a}$ & 8 & 0.90 & 0.14 & 0 & 0.09 & 0.58 & 0.37 \\
\hline & $-04^{b}$ & 2 & 0.05 & 0 & 0 & 0 & 0.46 & 0.09 \\
\hline
\end{tabular}

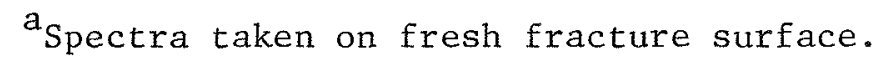

${ }^{\mathrm{b}}$ Sputtered for 2 min. Sputtering conditions were set to remove the equivalent of one atom layer of $\mathrm{Ta}_{2} \mathrm{O}_{5}$ per minute of sputtering time. 


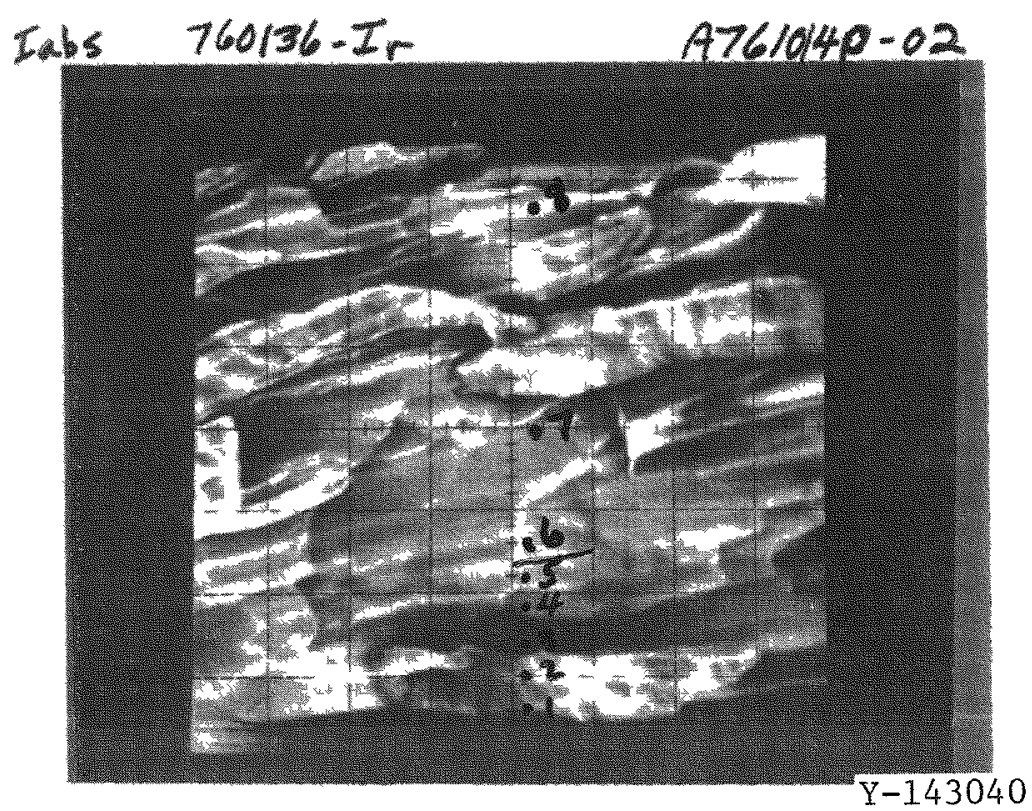

Fig. 2.7. A Sample Current Image of the Fracture Surface of Sample 760136, Showing the Spots Where Auger Spectra Were Taken. 
Table 2.9. Summary of Auger Results for Sample 760158 (MHT-90, w/o Weld)

\begin{tabular}{|c|c|c|c|c|c|c|c|}
\hline \multicolumn{2}{|c|}{ Chart } & Spot & $x / t$ & $\frac{\mathrm{I}(\mathrm{Th}, 67 \mathrm{eV})}{\mathrm{I}(\mathrm{Ir}, 54 \mathrm{eV})}$ & $\frac{\mathrm{I}(\mathrm{P}, 120 \mathrm{eV})}{\mathrm{I}(\mathrm{Ir}, 229 \mathrm{eV})}$ & $\frac{\mathrm{I}(\mathrm{C}, 272 \mathrm{eV})}{\mathrm{I}(\mathrm{Ir}, 229 \mathrm{eV})}$ & $\begin{array}{l}\mathrm{I}(0,512 \mathrm{eV}) \\
\mathrm{I}(\mathrm{Ir}, 229 \mathrm{eV})\end{array}$ \\
\hline A761116 & $C-01^{a}$ & A & 0.44 & 0.18 & 0 & 0 & 0 \\
\hline & $-03^{a}$ & 1 & 0.29 & 0.13 & 0.07 & 0.12 & 0.12 \\
\hline & $-04^{a}$ & 2 & 0.18 & 0.16 & 0.95 & 0.15 & 0.21 \\
\hline & -05 & 3 & 0.11 & 0.06 & 1.08 & 0.13 & 0.15 \\
\hline & -06 & 4 & 0.03 & 0.02 & 1.23 & 0.12 & 0.38 \\
\hline & -07 & 5 & 0.98 & 0 & 0 & 0.58 & 0.95 \\
\hline & -08 & 6 & 0.87 & 0.07 & 0 & 0.80 & 0.12 \\
\hline & -09 & 7 & 0.71 & $b$ & 0 & 0.29 & 0 \\
\hline & -10 & 8 & 0.60 & 0.07 & 0 & 0.22 & 0.16 \\
\hline A761117 & $C-04^{c}$ & 4 & 0.03 & 0 & 0 & 0.29 & 0.07 \\
\hline & $-05^{c}$ & 2 & 0.18 & 0 & 0 & 0.32 & 0.08 \\
\hline
\end{tabular}

${ }^{a}$ Sputtering conditions were set to remove the equivalent of one atom layer of $\mathrm{Ta}_{2} \mathrm{O}_{5}$ per minute of sputtering time.

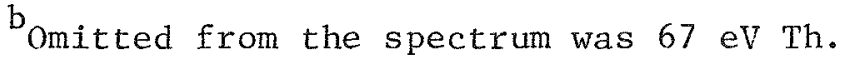

${ }^{c}$ Sputtered for $2 \mathrm{~min}$. Sputtering conditions were set to remove the equivalent of one atom layer of $\mathrm{Ta}_{2} \mathrm{O}_{5}$ per minute of sputtering time. 
Table 2.10. Summary of Auger Results for Sample 760157 (MHT-90, with Weld)

\begin{tabular}{|c|c|c|c|c|c|c|c|}
\hline \multicolumn{2}{|c|}{ Chart } & Spot & $x / t$ & 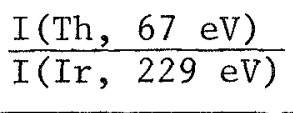 & 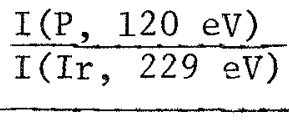 & $\frac{I(C, 272 \mathrm{eV})}{I(I r, 229 \mathrm{eV})}$ & $\frac{\mathrm{I}(0,272 \mathrm{eV})}{\mathrm{I}(\mathrm{Ir}, 229 \mathrm{eV})}$ \\
\hline A761116 & $\mathrm{C}-11^{\mathrm{a}}$ & 1 & 0.51 & 0.15 & 0 & 0.08 & 0 \\
\hline & $-13^{a}$ & 2 & 0.08 & 0.09 & 0.02 & 0.22 & 0.18 \\
\hline \multirow[t]{5}{*}{ A761117 } & $\mathrm{C}-01^{\mathrm{a}}$ & 3 & 0.92 & 0.13 & 0.03 & 0.57 & 0.16 \\
\hline & $-02^{a}$ & 4 & 0.08 & 0.03 & 0.02 & 0.45 & 0 \\
\hline & $-03^{a}$ & 5 & 0.05 & 0.18 & 0.98 & 0.40 & 0.18 \\
\hline & $-06^{b}$ & 5 & 0.05 & 0 & 0 & 0.26 & 0 \\
\hline & $-07^{b}$ & 1 & 0.51 & 0 & 0 & 0.28 & 0 \\
\hline
\end{tabular}

${ }^{a}$ Spectra taken on fresh fracture surface.

${ }^{b}$ Sputtered for 2 min. Sputtering conditions were set to remove the equivalent of one atom layer of $\mathrm{Ta}_{2} \mathrm{O}_{5}$ per minute of sputtering time. 


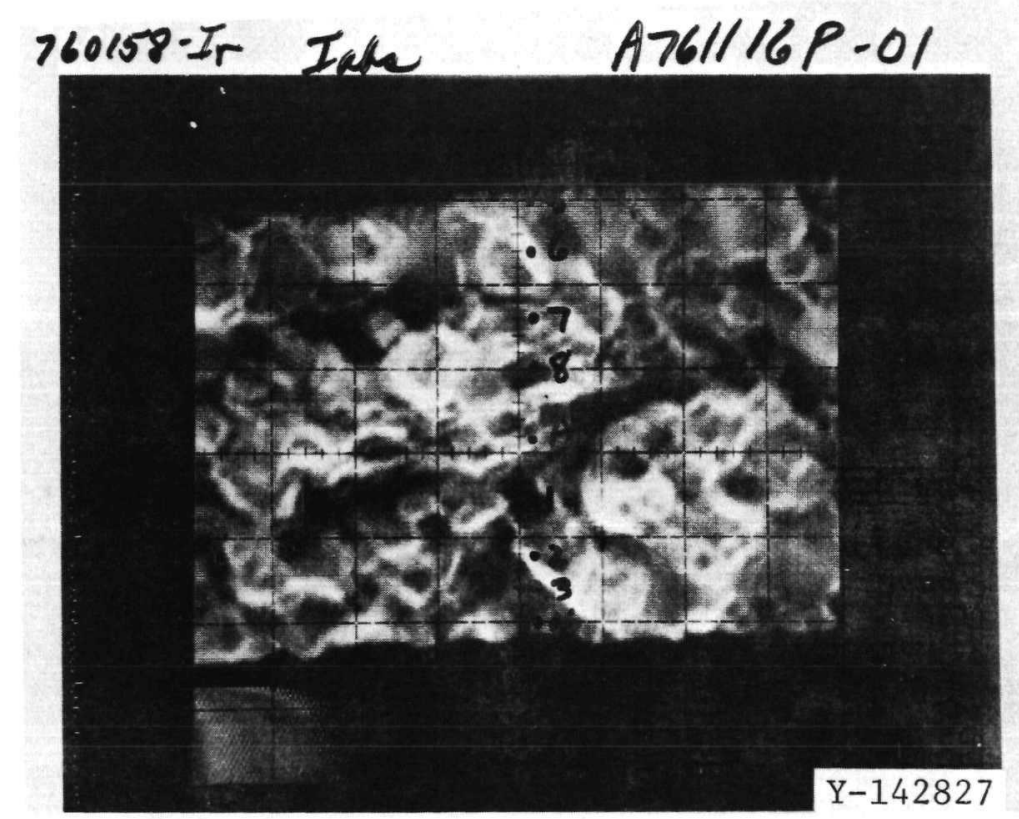

Fig. 2.8. A Sample Current Image of the Fracture Surface of Sample 760158, Showing the Spots Where Auger Spectra Were Taken. 


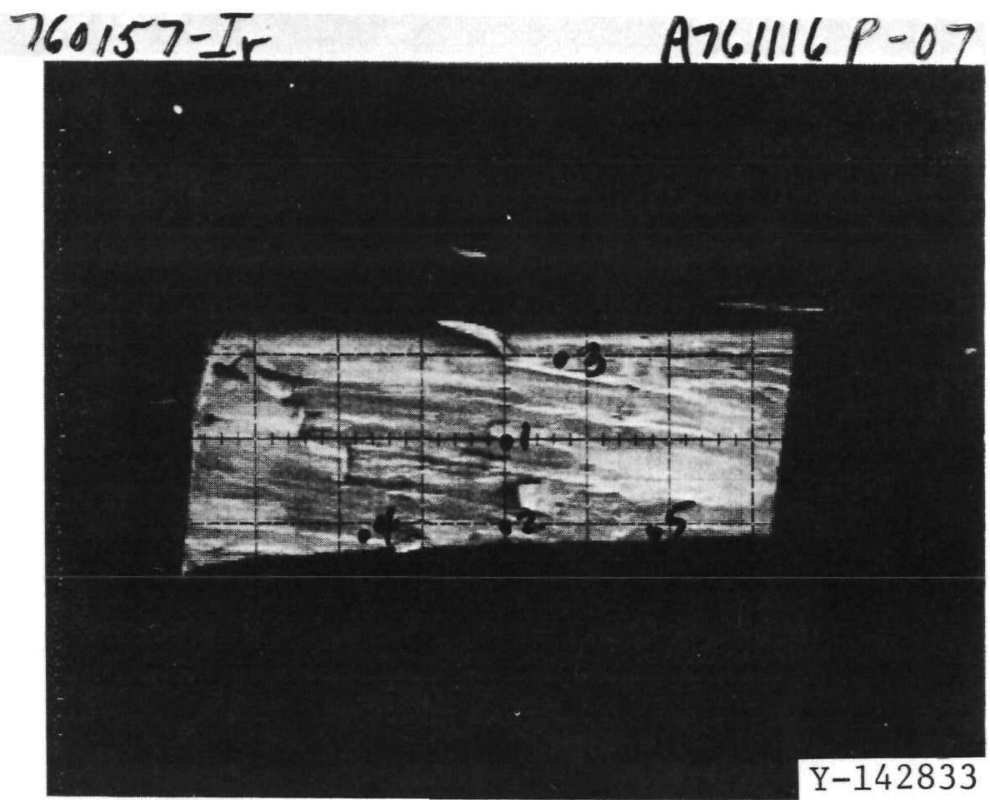

Fig. 2.9. A Sample Current Image of the Fracture Surface of Sample 760157, Showing the Spots Where Auger Spectra Were Taken. 
Table 2.11. Summary of Auger Results for Sample 760185 (MHT-92, w/o Weld)

\begin{tabular}{|c|c|c|c|c|c|c|c|c|}
\hline \multicolumn{2}{|c|}{ Chart ${ }^{a}$} & Spot & $x / t$ & $\frac{I(\mathrm{Th}, 67 \mathrm{eV})}{I(\mathrm{Ir}, 64 \mathrm{eV})}$ & $\frac{\mathrm{I}(\mathrm{P}, 120 \mathrm{eV})}{\mathrm{I}(\mathrm{Ir}, 229 \mathrm{eV})}$ & \multirow[t]{2}{*}{$\frac{\mathrm{I}(\mathrm{S}, 152 \mathrm{eV})}{\mathrm{I}(\mathrm{Ir}, 229 \mathrm{eV})}$} & $\frac{\mathrm{I}(\mathrm{C}, 272 \mathrm{eV})}{\mathrm{I}(\mathrm{Ir}, 229 \mathrm{eV})}$ & $\frac{\mathrm{I}(0,510 \mathrm{eV})}{\mathrm{I}(\mathrm{Ir}, 229 \mathrm{eV})}$ \\
\hline A7 61221 & $\mathrm{C}-01$ & 1 & 0.52 & 0.15 & 0.11 & & 0.42 & 0.14 \\
\hline & -03 & 2 & 0.03 & 0.01 & 0.86 & 0 & 0.86 & 0.24 \\
\hline & -04 & 3 & 0.97 & 0.03 & 0.09 & 3.08 & 0.54 & 0.39 \\
\hline A761222 & $\mathrm{C}-01$ & 4 & 0.03 & 0.08 & 0.60 & 0 & 0.67 & 0.28 \\
\hline & -02 & 5 & 0.03 & 0.05 & 0.29 & 2.67 & 1.24 & 0.51 \\
\hline & -03 & 6 & 0.90 & 0.05 & 0.17 & 0 & 0.93 & 0.18 \\
\hline A761227 & $\mathrm{C}-0 \mathrm{I}$ & 2 & 0.03 & 0.02 & 0.66 & 0 & 1.41 & 0.25 \\
\hline
\end{tabular}

${ }_{\text {A11 }}$ spectra taken on fresh fracture surface. 
Table 2.12. Summary of Auger Results for Sample 760184 (MHT-92, with We1d)

\begin{tabular}{rcccccc}
\hline \multicolumn{1}{c}{ Chart } & Spot & $x / t$ & $\frac{\mathrm{I}(\mathrm{Th}, 67 \mathrm{eV})}{\mathrm{I}(\mathrm{Ir}, 54 \mathrm{eV})}$ & $\frac{\mathrm{I}(\mathrm{P}, 120 \mathrm{eV})}{\mathrm{I}(\mathrm{Ir}, 229 \mathrm{eV})}$ & $\frac{\mathrm{I}(\mathrm{C}, 272 \mathrm{eV})}{\mathrm{I}(\mathrm{Ir}, 229 \mathrm{eV})}$ & $\frac{\mathrm{I}(0,510 \mathrm{eV})}{\mathrm{I}(\mathrm{Ir}, 229 \mathrm{eV})}$ \\
\hline $\mathrm{A} 761227 \mathrm{C}-08^{\mathrm{a}}$ & 1 & 0.63 & 0.12 & 0 & 0.11 & 0 \\
$-09^{\mathrm{a}}$ & 2 & 0.04 & 0.10 & 0.64 & 0.44 & 0.22 \\
$\mathrm{~A} 761228 \mathrm{C}-01^{\mathrm{a}}$ & 3 & 1.00 & 0.06 & 0 & 0.35 & 0.20 \\
$-02^{\mathrm{a}}$ & 4 & 0.04 & 0.07 & 0.37 & 0.41 & 0.22 \\
$-03^{\mathrm{a}}$ & 5 & 0.04 & 0.01 & 0.52 & 0.37 & 0.28 \\
$-04^{\mathrm{a}}$ & 6 & 0.07 & 0.04 & 0.62 & 0.62 & 0 \\
$-05^{\mathrm{b}}$ & 5 & 0.04 & 0 & 0 & 0.50 & 0 \\
$-06^{\mathrm{b}}$ & 6 & 0.07 & 0 & 0 & 0
\end{tabular}

a Spectra taken on fresh fracture surface.

$\mathrm{b}_{\text {Sputtered for }} 2 \mathrm{~min}$. Sputtering conditions were set to remove the equivalent of one atom layer of $\mathrm{Ta}_{2} \mathrm{O}_{5}$ per minute of sputtering time. 


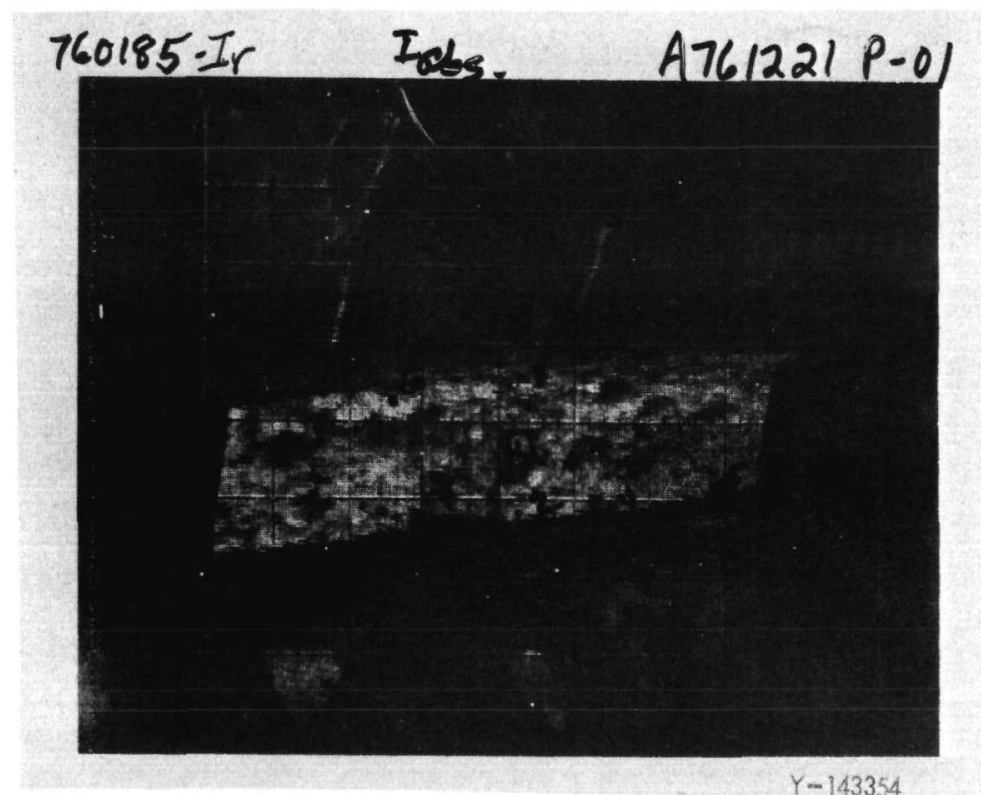

Fig. 2.10. A Sample Current Image of the Fracture Surface of Sample 760185, Showing the Spots Where Auger Spectra Were Taken. 


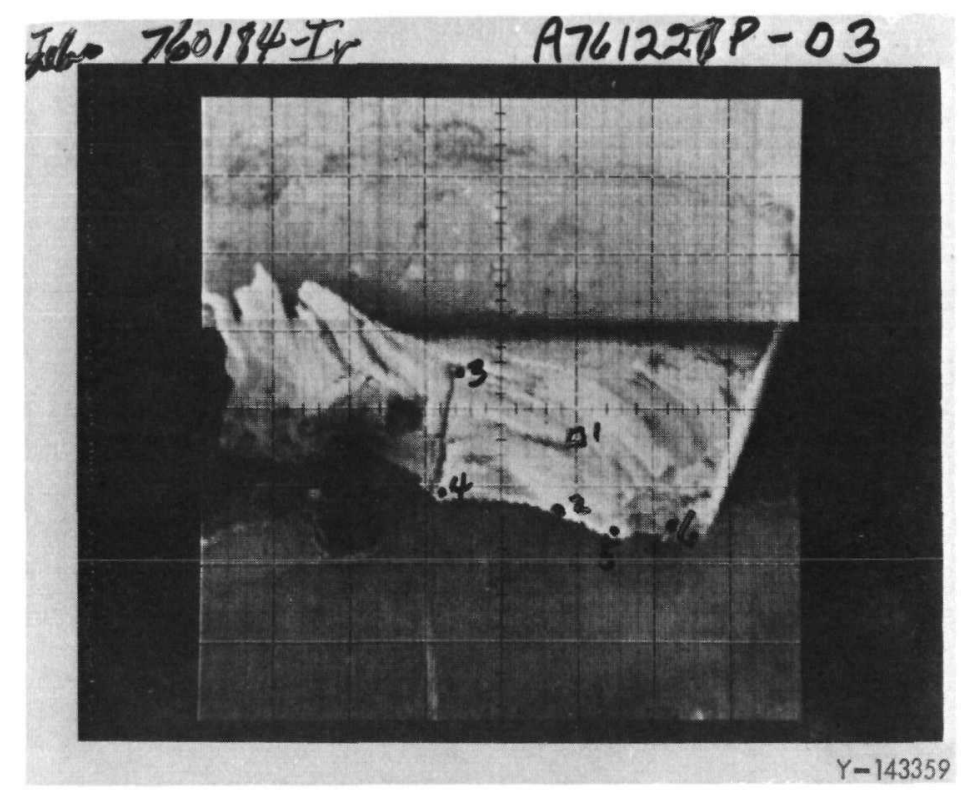

Fig. 2.11. A Sample Current Image of the Fracture Surface of Sample 760184, Showing the Spots Where Auger Spectra Were Taken. 
Table 2.13. The various spots that were analyzed were grouped according to their values of $x / t$. Spots with $x / t \leq 0.25$ were classified as being in the inner edge and those with $x / t \geq 0.75$ were grouped in the outer edge. All other spots were grouped in the middle region. Table 2.13 shows the average peak height ratios for MHT-90, -91 , and -92 according to region, with the available data from MHT-103 and -104 for comparison. As with any condensation of data, some information is lost, and reference should be made to Tables 2.7 through 2.12 for details.

Table 2.13. Summary of Auger Results on the Distribution of Phosphorus and Thorium

\begin{tabular}{llcc}
\hline \multirow{2}{*}{ Alloy } & Region & $\frac{I(\mathrm{Th}, 67 \mathrm{eV})}{\mathrm{I}(\mathrm{Ir}, 54 \mathrm{eV})}$ & $\frac{I(\mathrm{P}, 120 \mathrm{eV})}{\mathrm{I}(\mathrm{Ir}, 229 \mathrm{eV})}$ \\
\hline MHT-90,-91, & Outer & 0.052 & 0.029 \\
and -92 & Midd1e & 0.079 & 0.012 \\
& Inner & 0.056 & 0.708 \\
MHT-103 & Outer & 0.050 & 0 \\
and -104 & Midd1e & 0.043 & 0.869 \\
& Inner & 0.020 & 2.234 \\
\hline
\end{tabular}

Table 2.13 clearly indicates the high $\mathrm{P}$ concentration in the inner edge relative to the middle region and top edge. It also shows that the average $\mathrm{P}$ concentration in the inner edges of MHT-103 and -104 was more than three times as large as the average for the inner edges of MHT-90, -91 , and -92 . The difference between the average peak height ratios for the middle regions and top edges of MHT-90, -91, and -92 may not be statistically significant since the standard deviation from the average was larger than the averages themselves.

The averages of the thorium peak height ratios in Table 2.13 show a slight indication that the middle region of the fracture surface may be richer in thorium than the bottom and top edges. Small and large thorium peaks were found at both edges and the centers of the fracture surfaces. Analysis of the thorium peak was complicated by oxygen contamination, the small size of the thorium peak, and the strongly sloping background. Additional scatter may result from thorium having different binding 
energies for the different grain boundaries making up the fracture surface. Because of the large amount of scatter in the results for thorium, the differences between the outer edges, middle regions, and inner edges of MHT $-90,-91$, and -92 may not be statistically significant.

The sulfur observed on MHT-91 and -92 is puzzling. Many metals are strongly embrittled by sulfur, yet MHT-91 and -92 , which had significant contamination, were superior to MHT-103 and -104 which showed no sign of sulfur contamination. Additional analysis will be necessary if the significance of the sulfur on these samples is to be understood.

The one factor common to all of the samples described in Table 2.5 is the contamination of the grain boundaries near the inner edge of the fracture surface with $P$. The ratios of $I(P, 120 \mathrm{eV})$ to $I(I r, 229 \mathrm{eV})$ are plotted as a function of $x / t$ in Fig. 2.12 for all of the samples in Table 2.5. Values from MHT-103 and -104 are plotted as solid symbols and values from MHT-90, -91 , and -92 are plotted as open symbo1s. Samples from MHT-103 and -104 clearly have more extensive $P$ contamination than samples from MHI-90, -91 , and -92 . This makes it seem likely that the increased $P$ contamination in MHT-103 and -104 is responsible for the cladding failure.

\subsubsection{Analysis of Precipitate-Matrix Interfaces in Ir $-0.3 \% \quad \mathrm{~W}-0.1 \%$ Th Alloys}

Auger electron spectroscopic analysis of the interface between thoriumrich precipitates (possibly $\operatorname{Ir}_{5} \mathrm{Th}$ ) and the Ir-W-Th solid solution has been obtained using an improved scanning Auger microprobe.* This instrument can obtain AES analysis using primary electron beams as small as $0.5 \mu \mathrm{m}$ in diameter, hence making it possible to analyze the surface of precipitate particles on the intergranular fracture surfaces of the Ir $-0.3 \% \mathrm{~W}-0.1 \mathrm{Th}$ alloy. The sample used for this purpose (760160) had been heat treated 1 hr at $1500^{\circ} \mathrm{C}$.

This analysis was undertaken in order to determine whether the chemistry of the precipitate-matrix interface is significantly different from the chemistry of the grain boundary. This information is required in order to evaluate the results of previous AES analysis using primary electron beams that are too large to allow individual precipitates to be resolved.

\footnotetext{
${ }^{*}$ Model 590 Scanning Auger Microprobe, manufactured by Physical Electronics Industries.
} 


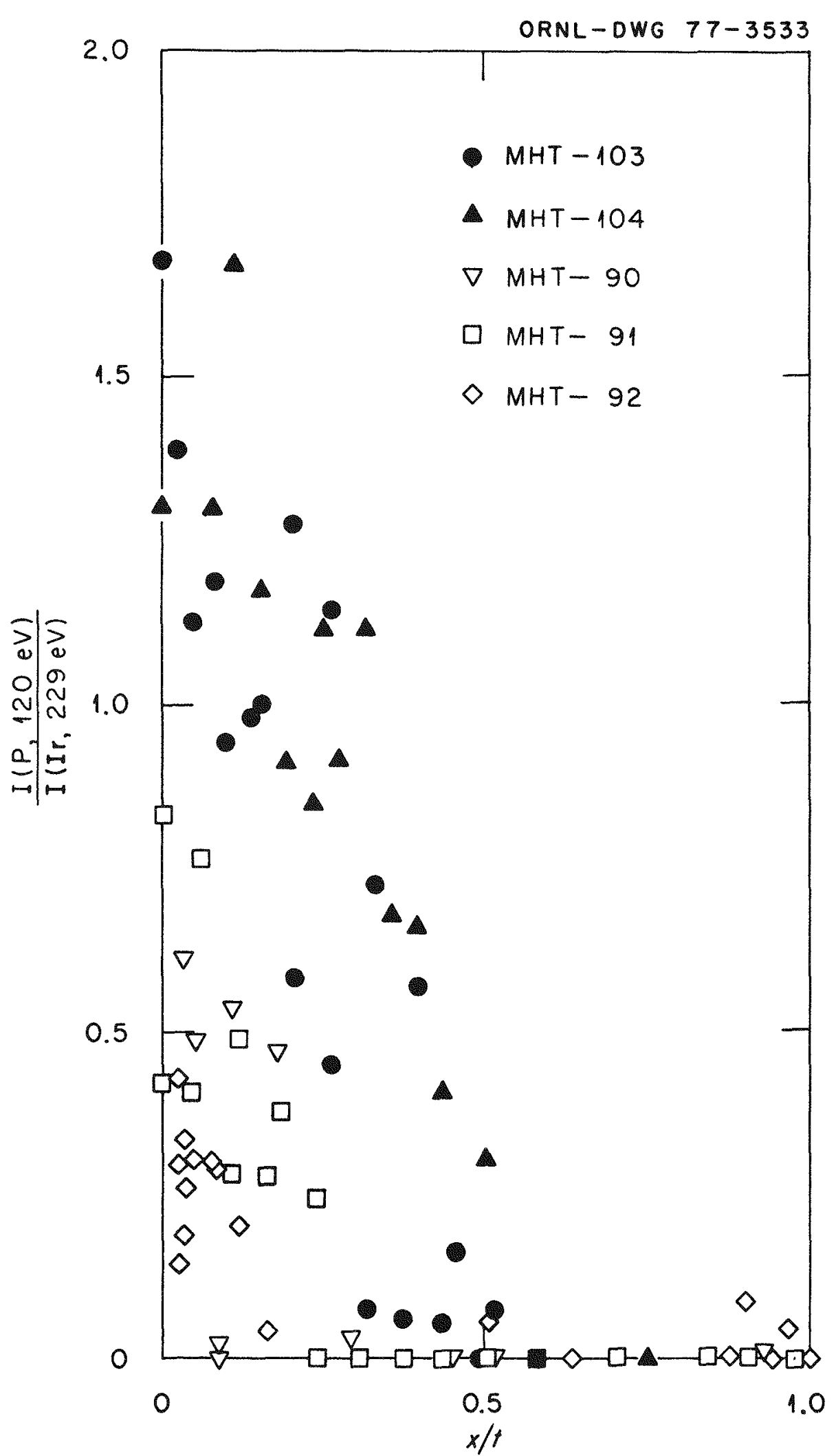

Fig. 2.12. A Plot of the Ratio I(P, $120 \mathrm{eV}) / \mathrm{I}(\mathrm{Ir}, 20 \mathrm{eV})$ as a Function of the Ratio $x / t$ for All Samples on Table 2.5. Open symbols represent data from MHT-90, -91 , and -92 that had acceptable impact performance; solid symbols represent data from MHT-103 and -104 that failed the simulant fuel. impact tests. 
Auger analysis using these larger electron beams results in an average over regions partially covered with precipitate particles.

Figure 2.13 shows two partial Auger spectra, one from a precipitate surface, and the other from a spot on the adjacent grain boundary fracture surface. A secondary electron image, including this portion of the fracture surface, is shown in Fig. 2.14. The ratio of I(Th, $67 \mathrm{eV}$ ) to I (Ir, $54 \mathrm{eV}$ ) is about 0.27 for the spectrum taken on the precipitate as compared to a ratio of about 0.09 for the spectrum taken on the region adjacent to the precipitate. Several other precipitates were similarly examined, and while there was considerable variability in the peak height ratios, the average for analysis taken on the precipitates is about 0.26 while the average for analysis taken on the grain boundary fracture surfaces is about 0.09 . Complete Auger spectra taken on one of the precipitates did not indicate any other significant differences between the precipitates and the grain boundaries.

These results suggest that while the precipitate surfaces are richer in thorium than the grain boundary surfaces, the difference is probably not so large as to require correction of analysis where individual precipitates were not spatially resolved.

\subsection{References}

1. A. C. Schaffhauser, Isotopic Power Materials Development Quart. Progr. Rep. March 31, 1976, ORNL/TM-5482.

2. Correspondence from E. A. Walker, MRC to A. C. Schaffhauser, ORNL, "Weekly Highlights, Heat Source Branch, NRA, Week Ending November 19, 1976."

3. E. M. Cramer and S. S. Hecker, Postimpact Examinations of Three DOP 4 Iridium Shells from Simulant Fuel Sphere Assemblies, LA-6176-MS, February 1976.

4. A. C. Schaffhauser, Isotopic Power Materials Development Quart. Progr. Rep. Sept. 30, 1976, ORNL/TM-5810.

5. A. C. Schaffhauser, Isotopic Power Materials Development Quart. Progr. Rep. March 31, 1976, ORNL/TM-5482.

6. L. E. Davis et a1., Handbook of Auger EZectron Spectroscopy, 2nd, Physical Electronics Industries, Inc., Eden Prarie, Minnesota. 


$$
\begin{aligned}
& \text { Ir + } 0.3 \% \mathrm{~W}+0.1 \% \mathrm{Th} \\
& \text { HEAT WTh }-2 \\
& \text { ihr } / 1500^{\circ} \mathrm{C}
\end{aligned}
$$

FRESH FRACTURE SURFACE

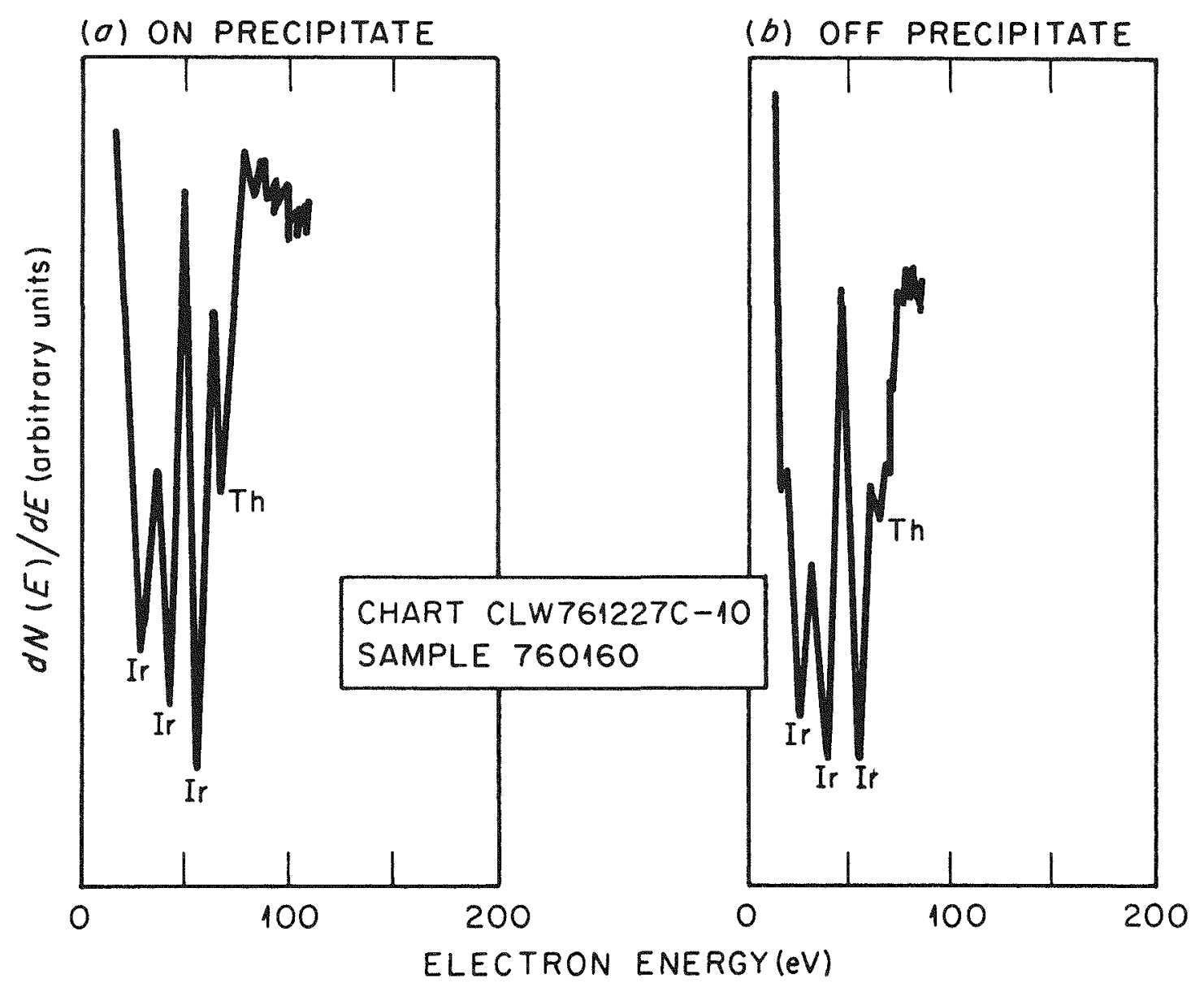

Fig. 2.13. Partial Auger Spectra from a Sample (760160) of Ir $-0.3 \% \mathrm{~W}-0.1 \%$ Th Alloy. Spectrum A was taken on a precipitate and spectrum $B$ was taken on the grain boundary fracture surface near the precipitate. 

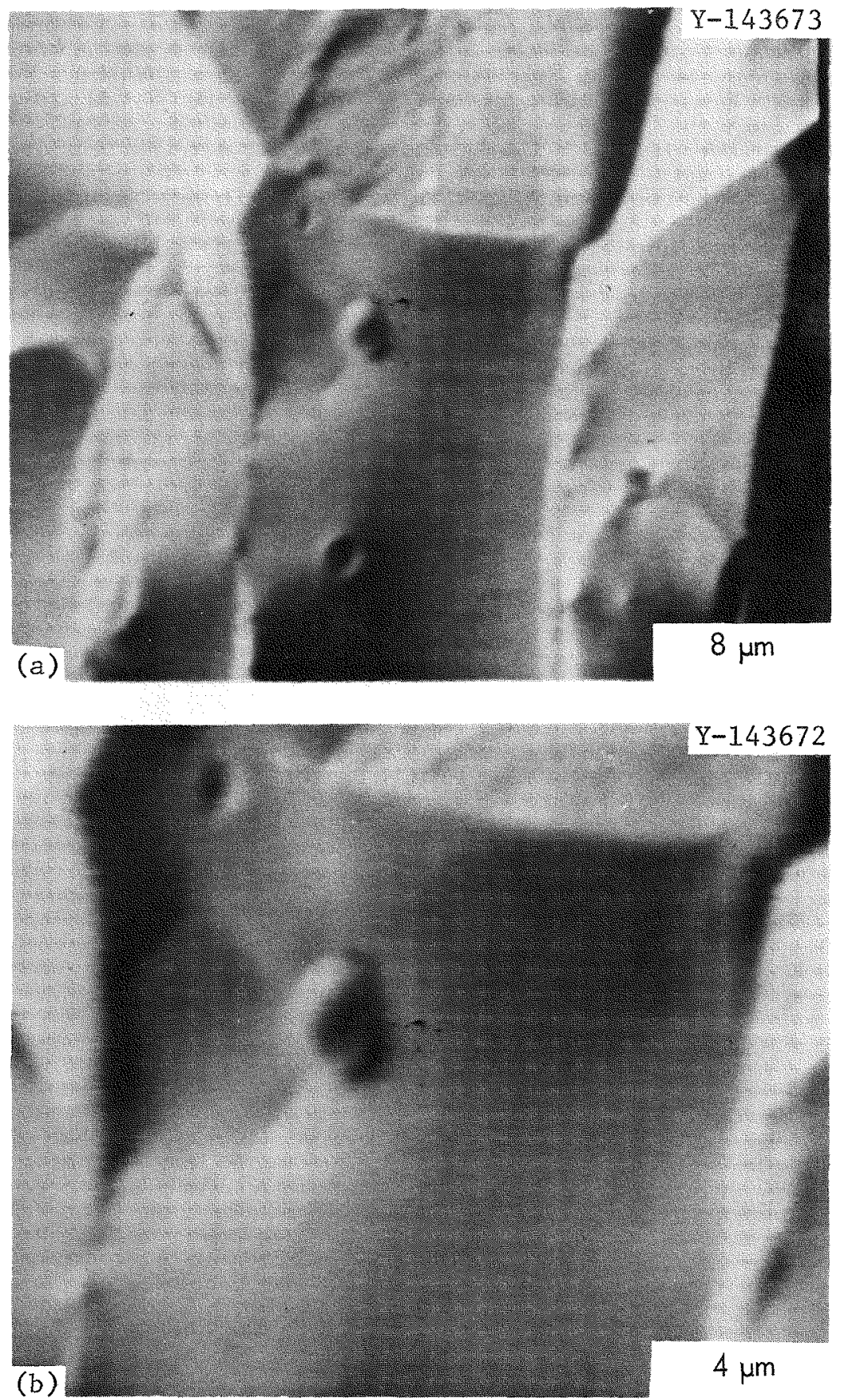

Fig. 2.12. A Plot of the Ratio $I(P, 120 \mathrm{eV}) / \mathrm{I}(\mathrm{Ir}, 20 \mathrm{eV})$ as a Function of the Ratio $x / t$ for Al1 Samples on Table 2.5. Open symbols represent data from MHT-90, -91 , and -92 that had acceptable impact performance, and solid symbols represent data from MHT-103 and -104 that failed the simulant fuel impact tests. 


\section{CURIUM-244 FUEL DEVELOPMENT**}

\subsection{Introduction}

Curium-244, which is present in irradiated nuclear fuel and is the waste from fuel recovery, has potential for use as a fuel in radioisotope heat sources. The objectives of this program are (1) to investigate potential methods for recovery of $\mathrm{Cm}-244$ from power reactor fuel wastes and (2) to determine the compatibility of ${ }^{244} \mathrm{Cm}_{2} \mathrm{O}_{3}$ with materails which might be suitable as fuel encapsulants in such heat sources. To accomplish these objectives, we are initiating compatibility tests of ${ }^{244} \mathrm{Cm}_{2} \mathrm{O}_{3}$ with various high-temperature alloys.

\subsection{Compatibility Test Matrix}

J. R. Keiser and J. R. DiStefano

Preparations have resumed for the ${ }^{244} \mathrm{Cm}_{2} \mathrm{O}_{3}$ compatibility testing program which was terminated in FY 1974. The test program calls for tensile specimens of selected alloys to be aged in contact with ${ }^{244} \mathrm{Cm}_{2} \mathrm{O}_{3}$. Alloys to be tested and their exposure conditions are given in Table 3.1. Most specimens and their capsule components were fabricated before the program was terminated, and these are still available. Three new alloys (noted in Table 3.1) will replace some of the previously selected alloys. ${ }^{1}$ Specimens of these new alloys will be fabricated when the technique for fabricating the required rectangular $\mathrm{Cm}_{2} \mathrm{O}_{3}$ pellets is demonstrated.

\subsection{Fuel Specimen Fabrication \\ C. L. Ottinger}

After an evaluation of the operational status of the Curium Source Fabrication Facility (CSFF), it was decided to investigate alternative facilities and methods for preparing the rectangular fuel pieces needed for the

\footnotetext{
${ }^{*}$ Progress on work performed under Activity No. KJ 060202 0, 189a No. 01367.
} 
Table 3.1. Revised Test Matrix for $\mathrm{Cm}_{2} \mathrm{O}_{3}$ Compatibility Tests

\begin{tabular}{lcc}
\hline $\begin{array}{c}500 \mathrm{hr} / 900^{\circ} \mathrm{C} \\
\text { Argon-Graphite }\end{array}$ & $\begin{array}{c}5000 \mathrm{hr} / 1100^{\circ} \mathrm{C} \\
\text { Vacuum-Graphite }\end{array}$ & $\begin{array}{c}10,000 \mathrm{hr} / 1400^{\circ} \mathrm{C} \\
\text { Vacuum-Graphite }\end{array}$ \\
\hline Pt-3008/TZM $^{\mathrm{a}}$ & $\mathrm{Pt}-3008$ & $\mathrm{Ir}-0.3 \% \mathrm{~W}^{\mathrm{b}}$ \\
Mo-46\% Re & $\mathrm{Mo}-46 \% \mathrm{Re}$ & $\mathrm{Mo}-46 \% \mathrm{Re}$ \\
$\mathrm{Ta}-10 \% \mathrm{~W}$ & $\mathrm{Ta}-10 \% \mathrm{~W}$ & $\mathrm{Ta}-10 \% \mathrm{~W}$ \\
Haste11oy s & & \\
Inconel 617 or Alloy $556^{\mathrm{b}}$ & & \\
\hline
\end{tabular}

\footnotetext{
a Outer container.

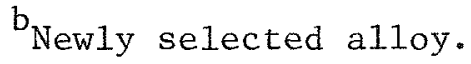

compatibility/tensile strength tests. The Isotope Research Materials Laboratory (IRML) of the Solid State Division, ORNL, has been very successful recently in preparing ceramic materials by an extrusion technique, and fabrication of the rectangular ${ }^{244} \mathrm{Cm}_{2} \mathrm{O}_{3}$ pellets can probably be done by this method. The ${ }^{244} \mathrm{Cm}$ experimental glove box line is not currently being used and has the essential services. Since refurbishing of the CSFF would be very expensive, and since experience with direct hot pressing of ${ }^{244} \mathrm{Cm}_{2} \mathrm{O}_{3}$ in rectangular form has not been good, a decision was made to attempt the fabrication by extrusion in the glove box facility.

Test dies are being fabricated and the needed equipment is being checked and repaired as necessary. The first experimental pressings should be made early in February to determine if the technique can be used. If the tests are successful, the production dies will need to be fabricated to yield the exact size of pellets required. It will be necessary to fabricate pellets one at a time due to radiation limitations, but this is considered preferable to the high-expense approach of the CSFF.

\subsection{References}

1. E. Lamb, ORNL Isotopic Power Fuels Quart. Progr. Rep. Dec. 31, 1973, ORNL-4939, p. 5 . 


\section{SELENIDE ISOTOPE GENERATOR SYSTEM SUPPORT*}

\subsection{Introduction}

This program provides materials support for the Selenide Isotope Generator (SIG) System to the systems contractors (Teledyne Energy Systems and $3 \mathrm{M}$ Company). Currently, emphasis is on providing the materials, components, and technology required for the SIG Ground Demonstration System (GDS), scheduled for operation in 1978. The three major task areas are (1) Isolation Hot Frame (IHF) fabrication development, (2) compatibility and property evaluation of the Pt-3008 alloy selected for the IHF with the system materials and environments, and (3) characterization of proposed thermal insulation materials. The IHF is designed to isolate the isotope heat source environment from the selenide thermoelectric module portion of the system. The Pt -3008 alloy (Pt-30\% Rh-8\% W) was selected for the IHF because of its compatibility with graphite and good creep strength. We are providing material and technology for the development and component fabrication of the IHF cylinder and bellows. The task on compatibility includes evaluation of the effects on the mechanical properties of Pt-3008 of potential interactions with other system components such as insulations and selenide thermoelectric materials. The insulation evaluation task includes characterization of the microstructural and chemical composition, thermal stability, and compatibility with graphite.

\subsection{Isolation Hot Frame Fabrication Development \\ R. L. Heestand}

We are assisting Teledyne Energy Systems by developing fabrication techniques and providing the Pt-3008 hardware associated with the Isolation Hot Frame (IHF) for the Selenide Isotope Generator System. This consists of a cylindrical can and bottom approximately $188.8 \mathrm{~mm}$ (7.43 in.) oD $x$ $139.7 \mathrm{~mm}$ ( 5.50 in.) high $\times 0.38 \mathrm{~mm}$ (0.015 in.) thick, a bellows $0.28 \mathrm{~mm}$

\footnotetext{
*Progress on work performed under Activity No. KJ 0601010 , 189a No. 01405 and Activity No. KJ 070202 0, 189a No. 01320.
} 
(0.11 in.) thick attached to the top of the cylinder, and transition joints for attachment to the exterior she11. The size of the components require sheet of a greater size than had been rolled previously. Sheet rolling development is described in another section of this report. ${ }^{1}$

The bellows design requires relatively sharp and close tolerances. For this reason, the sheet material for the bellows was supplied to a commercial fabricator, Metal Bellows Corporation, who have the necessary equipment for the operation. Sheet from both arc-cast and extruded Pt-3008 and induction-melted $\mathrm{Pt}-3008$ was supplied. It was intended that the induction-melted material, which had not been qualified for hardware, be used for practice forming, and the arc-cast and extruded materials be used for prototype hardware.

At this time, tooling has been completed for forming the bellows and practice bellows from stainless steel have been formed to check the tooling. Since low-ductility is anticipated in the seam weld of the $\mathrm{Pt}-3008,{ }^{2}$ it is planned to introduce work by planishing the weld and stress relieve to provice a better structure for forming. In addition, since increasing the temperature to $200^{\circ} \mathrm{C}$ increases the ductility of $\mathrm{Pt}-3008$ sheet, it is planned to form the bellows at this temperature. Due to the limited amount of material and the additional time required for bellows fabrication, fabrication development of the cylinder and bottoms of the hot frame will be initiated upon receipt of sheet material from the third scale-up ingot.

\subsection{Compatibility Studies}

\section{J. R. Keiser}

\subsubsection{Initial Compatibility Screening Tests}

Utilization of Pt-3008 for the Isolation Hot Frame in the Selenide Isotope Generator System requires that compatibility of Pt-3008 with the various system components be cemonstrated. From an assessment of the potential reactions of the many materials expected to be used in this system, we concluded that there were three which should be quickly evaluated for their effect on Pt-3008: the thermoelectric material $\mathrm{Cu}_{2} \mathrm{Se}$ which has a rather high selenium partial pressure at elevated temperatures; the insulation Fiberfrax HiFi 660 which is composed of $\mathrm{Al}_{2} \mathrm{O}_{3}$ and $\mathrm{SiO}_{2}$, but 
which has rather high concentrations of impurities including $\mathrm{B}$, $\mathrm{Na}$, and Fe which could detrimentally affect the Pt-3008, and the Min-K TE 1400 insulation which, in combination with graphite, could undergo the reaction

$$
\mathrm{SiO}_{2}+\mathrm{C} \rightarrow \mathrm{Si}+\mathrm{CO}_{2}
$$

under the proposed operating conditions. Previous research has shown that silicon can diffuse into $\mathrm{Pt}-3008$ along the grain boundaries and can cause complete loss of ductility at $1316^{\circ} \mathrm{C}$.

The test program with exposure conditions is given in Table 4.1. Following exposure, the strength and ductility of the specimens were measured and compared with that of control specimens aged for the same time and temperature. The specimens exposed to the Min-K insulation/graphite combination showed no degradation of properties, but specimens exposed to $\mathrm{Cu}_{2} \mathrm{Se}$ and specimens exposed to Fiberfrax insulation showed significant losses in strength and ductility. Typical results for the specimens exposed to Fiberfrax showed losses in tensile strength of at least $20 \%$ and as much as $80 \%$, and losses in ductility of at least $50 \%$ and as much as $95 \%$ when compared with the control specimens. Metallographic examinations show a shift to an intergranular fracture mode. Examination of a fracture surface by means of Auger electron spectroscopy revealed approximately 5 at. \% of both $\mathrm{S}$ and $\mathrm{P}$. Sputtering results indicated that these elements existed only in a thin layer of the fracture surface. The specimens exposed to the $\mathrm{Cu}_{2}$ Se underwent a more severe degradation than did Fiberfrax-exposed specimens. Tensile strength losses ranged from 30 to $95 \%$ and the ductility was 50 to $100 \%$ less than it was for the control specimens. Metallographic examination indicated an intergranular fracture mode, and Auger examination showed a thin layer of selenium on the fracture surface. A more complete discussion of the Auger results is given in the next section.

These initial compatibility tests were intended to quickly screen some of the potential interactions under the "worse case" conditions. For this reason, materials on hand were used, and we made no attempt to optimize the pretest outgassing of the materials. As a result of this less than sufficient outgassing, the compatibility test results may indicate a more severe degradation than would be expected to occur with well outgassed starting material.

A follow-up series of compatibility tests is planned which will use the second scale-up heat of $\mathrm{Pt}-3008$ whose properties are better defined and 
Table 4.1. Selenide Generator Compatibility Tests Conducted

\begin{tabular}{lccc}
\hline Component & Conditions & $\begin{array}{c}\text { Time } \\
(\mathrm{hr})\end{array}$ & $\begin{array}{c}\text { Temperature } \\
\left({ }^{\circ} \mathrm{C}\right)\end{array}$ \\
\hline $\begin{array}{l}\text { Fiberfrax HiFi 660 } \\
\text { insulation }\end{array}$ & $\begin{array}{c}\text { In contact with } \\
\text { Pt-3008 }\end{array}$ & 1000 & $800,950,1100^{\mathrm{a}}$ \\
$\begin{array}{l}\text { Min-K in contact } \\
\text { with graphite }\end{array}$ & $\begin{array}{c}\text { In vicinity of } \\
\text { Pt-3008 }\end{array}$ & 1000 & $800,950,1100$ \\
$\mathrm{Cu}_{2} \mathrm{Se}$ & $\begin{array}{c}\text { In vicinity of } \\
\text { Pt-3008 }\end{array}$ & 1000 & $800,950,1100^{\mathrm{b}}$ \\
\hline
\end{tabular}

$a_{\text {The }} 1100^{\circ} \mathrm{C}$ capsule burst after short exposure.

$\mathrm{b}_{\text {The }} 1100^{\circ} \mathrm{C}$ capsule broke after $850 \mathrm{hr}$.

are typical of the material that will be utilized in the GDS. Materials to be tested with the Pt-3008 are (1) well outgassed Fiberfrax, (2) fibrous $\mathrm{Al}_{2} \mathrm{O}_{3}$ or the current choice for high-temperature insulation, and (3) $\mathrm{Cu}_{2} \mathrm{Se}$ with its temperature carefully controlled. In addition, the effectiveness of graphite barriers in preventing interactions will be evaluated. It is planned that some of these tests will be started by February 1977.

\subsubsection{Microanalysis Characterization - C. L. White}

4.3.2.1 Exposure of $\mathrm{Pt}-3008$ to Vapor from $\mathrm{Cu}_{2} \mathrm{Se}$. - A fractured tensile sample of $\mathrm{Pt}-3008$ that had shown low ductility in a tensile test was received from J. R. Keiser. This sample had been heat treated $1000 \mathrm{hr}$ at $950^{\circ} \mathrm{C}$ in an evacuated quartz tube that also contained a sample of $\mathrm{Cu}_{2}$ Se to simulate potential interactions with the selenide thermoelectric elements.*

The shorter of the two pieces (sample 760181) from the tensile sample was submitted for scanning electron microscopy (SEM), and a piece from the gage section of the larger piece was used to prepare a sample (760190) suitable for Auger analysis. Figure 4.1 shows the scanning electron micrographs of sample 760181. This sample clearly failed in an intergranular fashion, and showed some interesting faceting on the grain boundaries at points where three or four grains join together. From the appearance of the scanning micrographs, this faceting may be the result of some kind of corrosive

*The $\mathrm{Pt}-3008$ and $\mathrm{Cu}_{2}$ Se were encapsulated in such a way as to prohibit physical contact between them and still allow a common environment. 

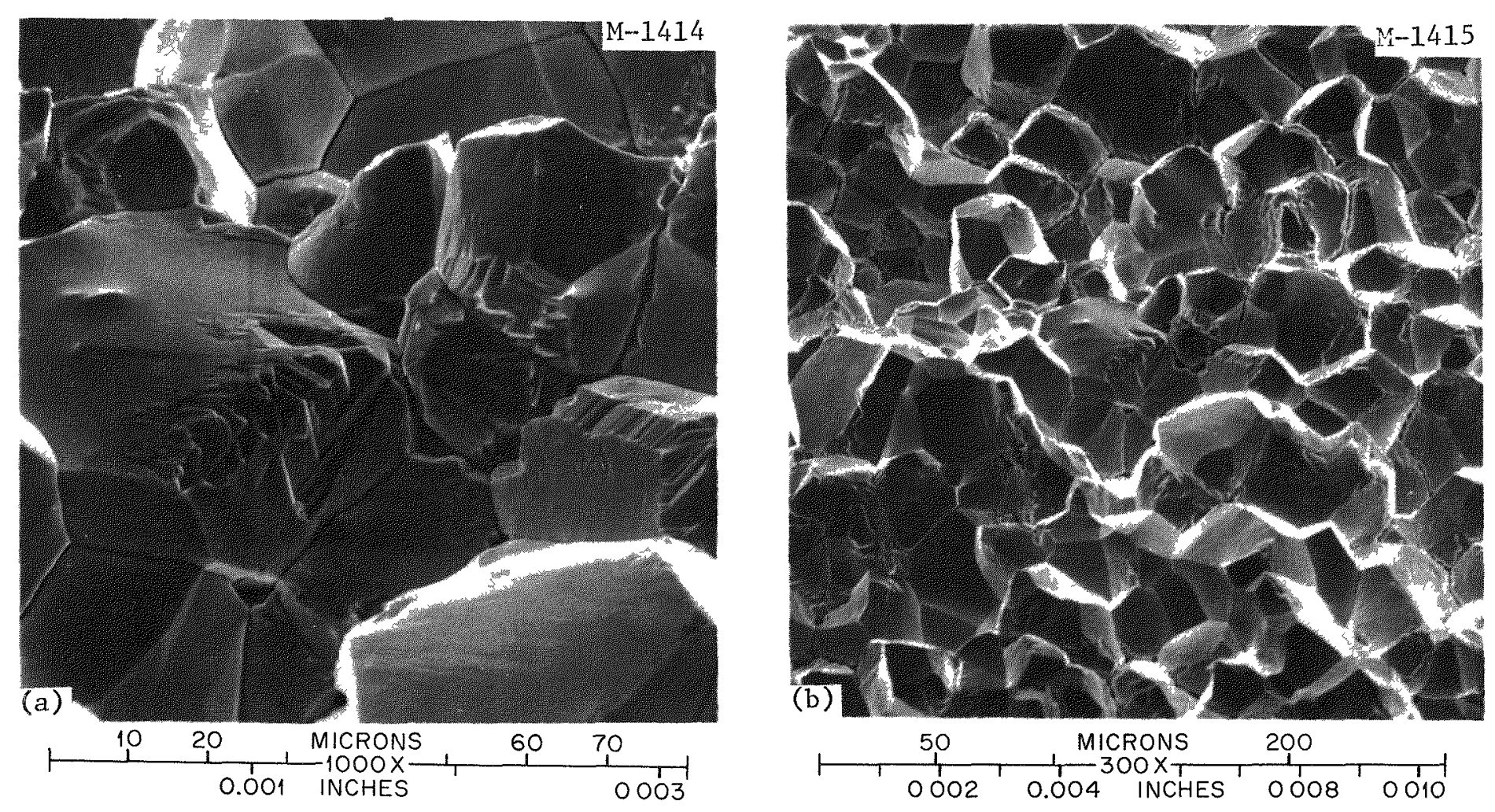

Fig. 4.1. Scanning Electron Micrographs of the Fracture Surface of Sample 760181. This Pt-3008 tensile sample had fractured in a brittle fashion after exposure to $\mathrm{Cu}_{2}$ Se vapor for $1000 \mathrm{hr}$ at $950^{\circ} \mathrm{C}$. Note the faceted appearance of the fracture surface at triple points. 
attack at the triple points, resulting in the loss of $\mathrm{Pt}, \mathrm{Rh}$, and/or $\mathrm{W}$ and the creation of an open network along the triple points. Optical metallography of a sample of $\mathrm{Pt}-3008$ that has had a similar exposure to $\mathrm{Cu}_{2} \mathrm{Se}$ is shown in Fig. 4.2. These photomicrographs also indicate the presence of an open network along the triple points.

The Auger spectrum from the fresh fracture surface of sample 760190 is shown in Fig. 4.3. The ratio $\mathrm{I}(\mathrm{Se}, 1318 \mathrm{eV}) / \mathrm{I}(\mathrm{Pt}, 1970 \mathrm{eV})$ is 0.48 . This is indicative of a $\mathrm{X}_{\mathrm{Se}} / \mathrm{X}_{\mathrm{Pt}}$ ratio of about $0.09 . *$ After sputtering the fracture surface for 2 min with inert gas ions, the ratio $I(S e, 1318 \mathrm{eV}) /$ $I(P t, 1970 \mathrm{eV})$ was reduced to 0.11 . The spectrum in Fig. 4.3 also shows small peaks due to $92 \mathrm{eV} \mathrm{Si}$ and $510 \mathrm{ev} 0$.

These results suggest that the extreme brittleness of Pt-3008 after exposure to $\mathrm{Cu}_{2} \mathrm{Se}$ at high temperatures may result from contamination of the grain boundaries by $\mathrm{Se}$ and/or the formation of an open network along the triple points which would have the effect of reducing the load-bearing cross section of the tensile sample. Additional analysis of more carefully prepared samples is planned in order to gain additional insight into this problem.

\subsubsection{Exposure of Pt-3008 to Fiberfrax Insulation. - A fractured} tensile specimen of $\mathrm{Pt}-3008$ that had been heated $1000 \mathrm{hr}$ at $950^{\circ} \mathrm{C}$ in contact with Fiberfrax insulation in a sealed quartz tube was received from J. R. Keiser. This specimen had failed in a brittle fashion during a tensile test at $950^{\circ} \mathrm{C}$, exhibiting an ultimate tensile strength of $22,019 \mathrm{MPa}$ and elongation of $2.9 \%$. Scanning electron micrographs of the fracture surface on the smaller of the two pieces of this specimen (sample 760195) are shown in Fig. 4.4 .

A small piece from the gage section of this tensile sample was used as an Auger sample (760194) which was analyzed in much the same way as sample 760190 (which was described previously). Figure 4.5 shows the Auger

*See note on p. 39 of this report concerning the conversion of peak height ratios to atom fraction ratios.

Tsputtering conditions were set so that the removal rate on $\mathrm{Ta}_{2} \mathrm{O}_{5}$ would be about one atom layer per minute. 


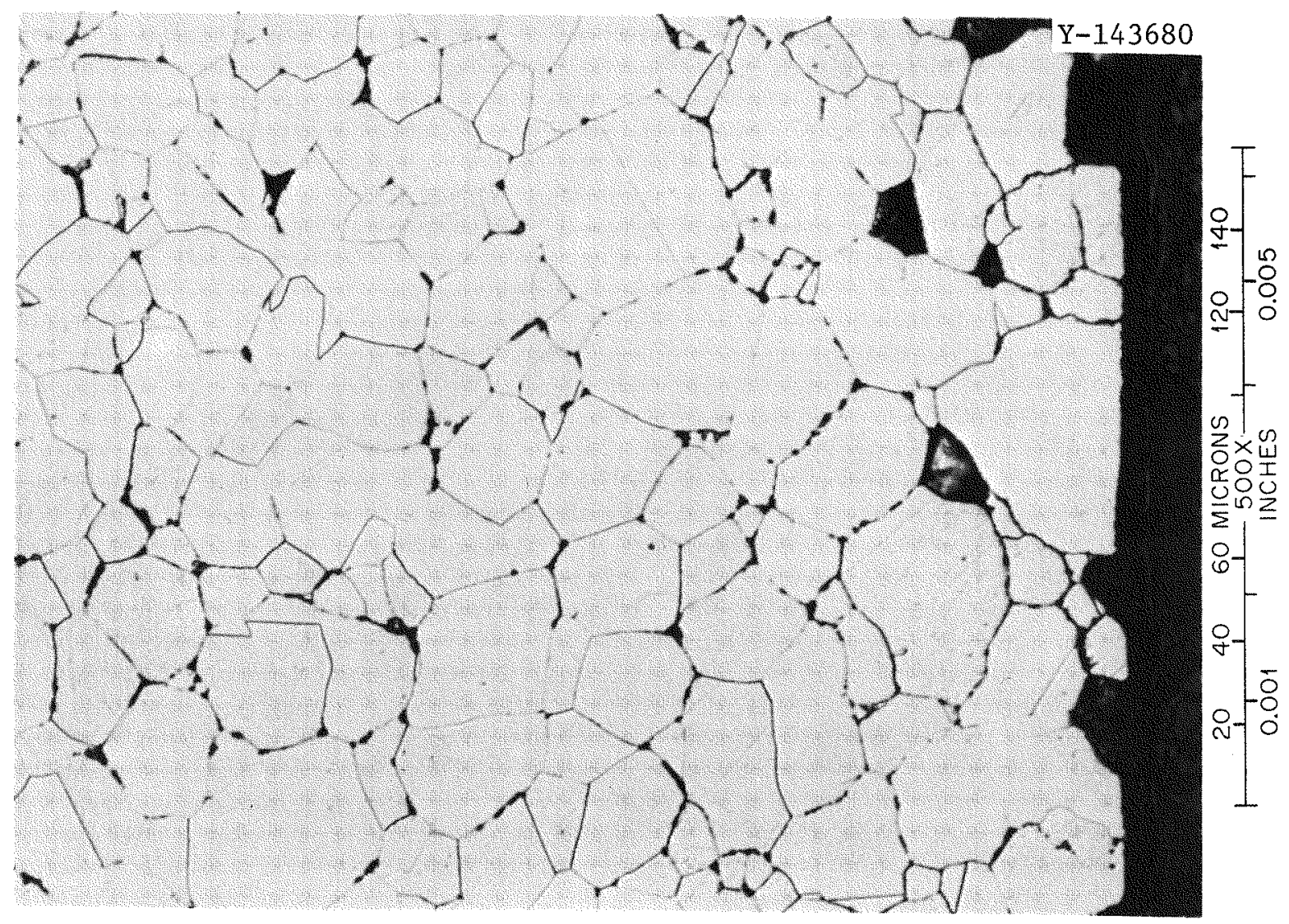

Fig. 4.2. Optical Photomicrograph of a Sample of Pt-3008 Having Same Exposure to $\mathrm{Cu}_{2} \mathrm{Se}$ as Sample 760181. 
ORNL-DWG $77-3538$
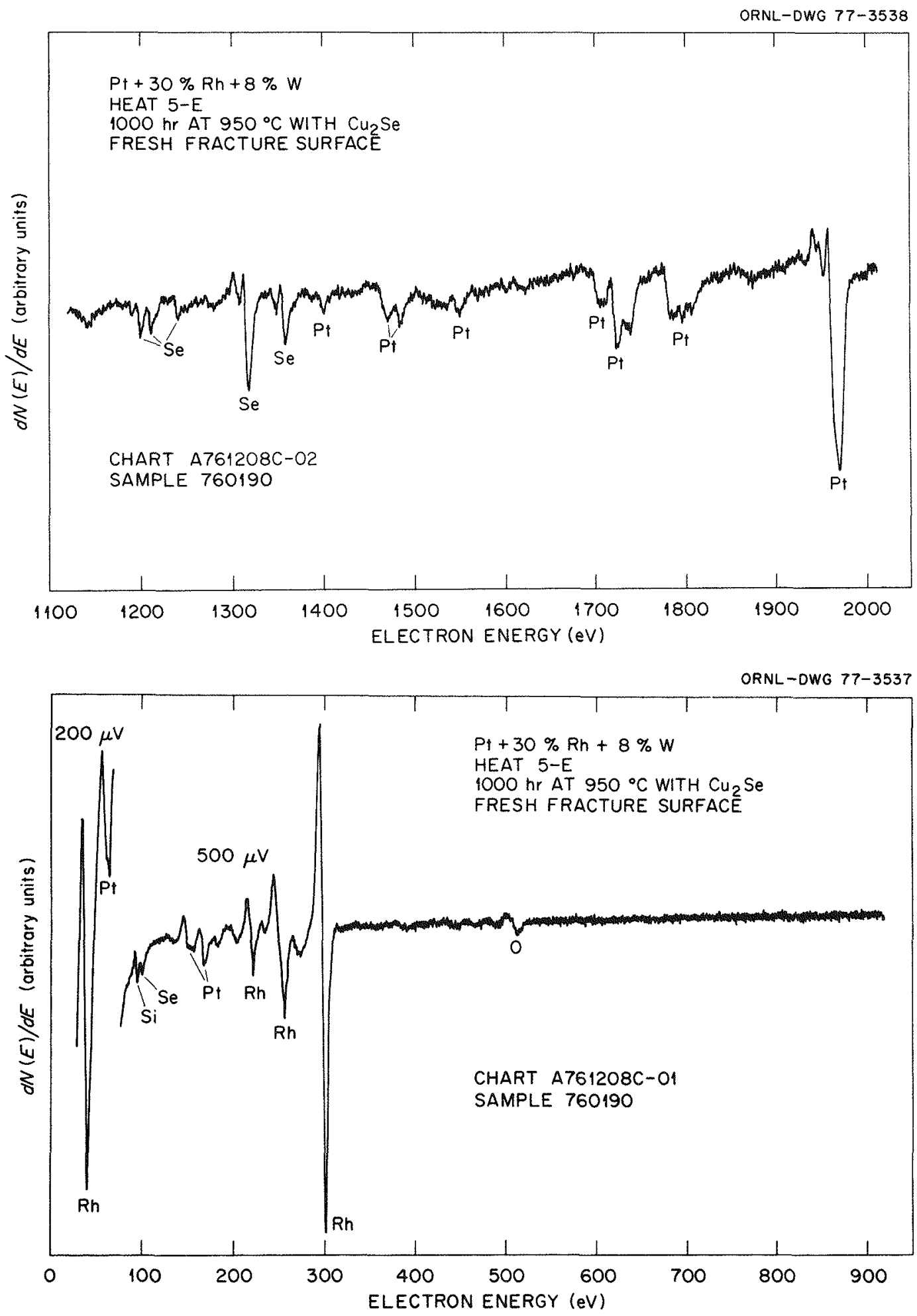

Fig. 4.3. An Auger Spectrum from the Fresh Fracture Surface of Sample 760190. This sample comes from the same tensile specimen as sample 760181. 

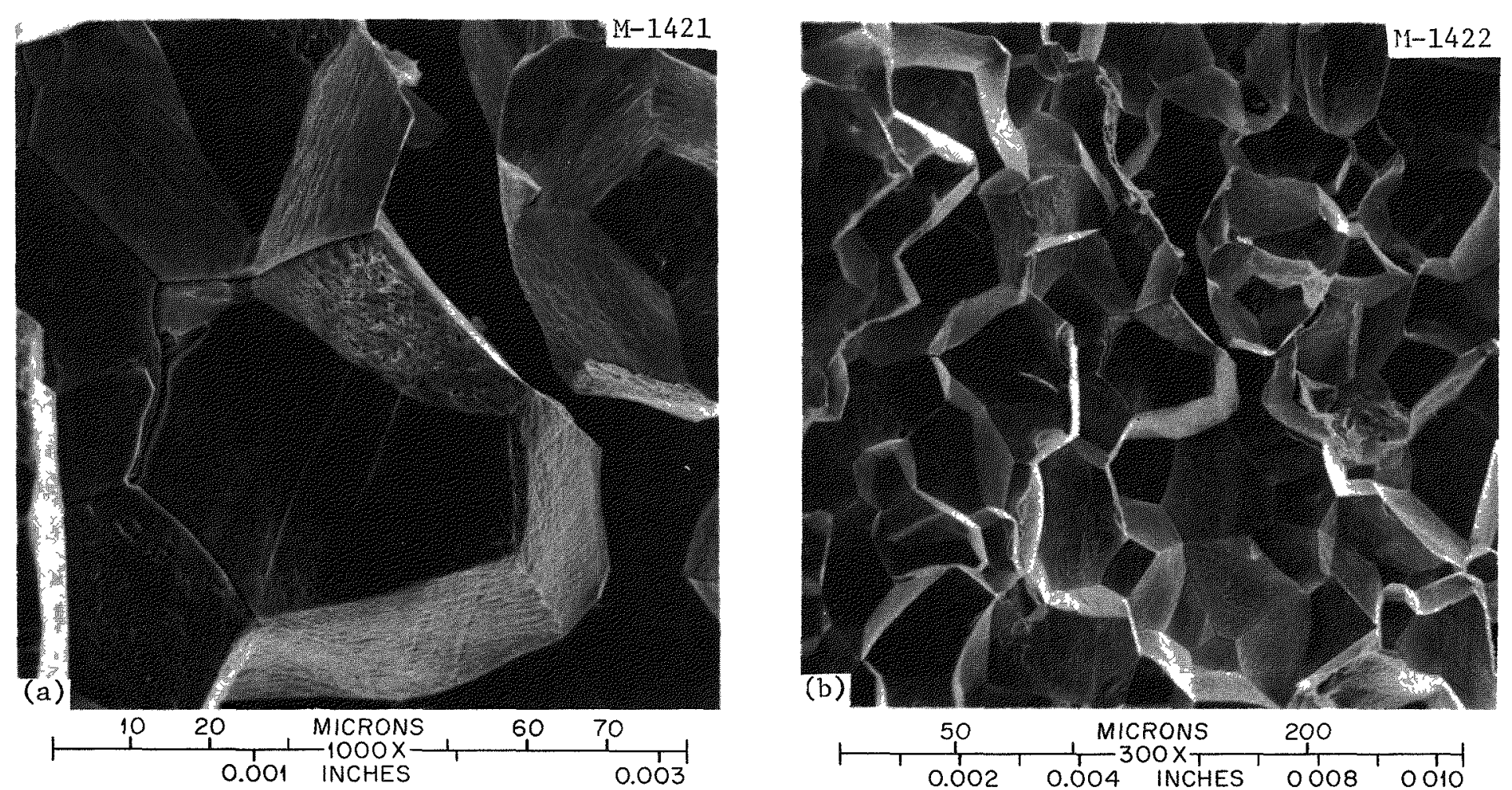

Fig. 4.4. Scanning Electron Micrographs of Sample 760195. This sample of Pt-3008 alloy was heated $1000 \mathrm{hr}$ at $950^{\circ} \mathrm{C}$ in contact with Fiberfrax insulation in an evacuated quartz capsule. 
ORNL-DWG $77-3535$
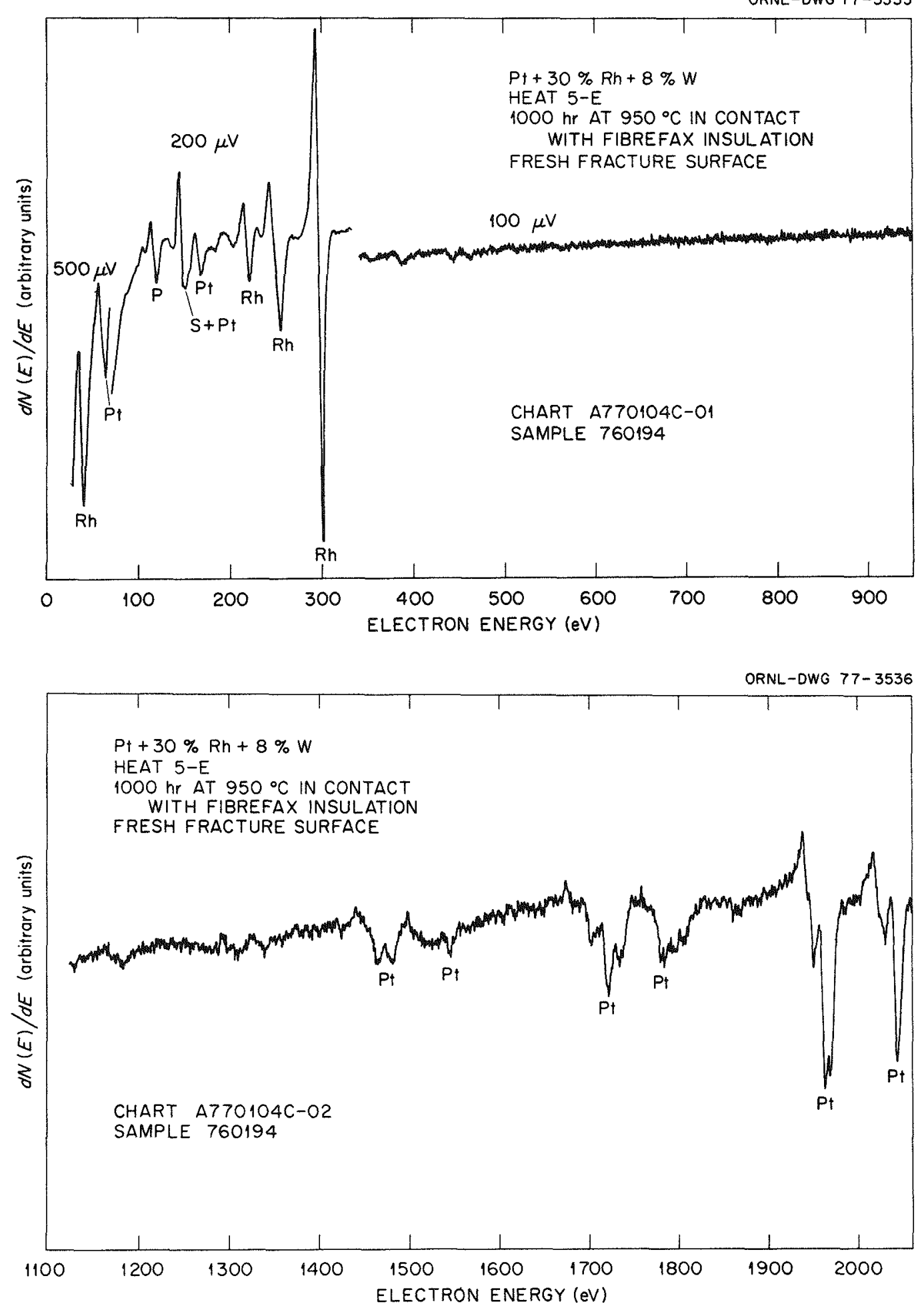

Fig. 4.5. An Auger Spectrum from the Fresh Fracture Surface of Sample 760194, Which Was Identical to Sample 760195 in Fig. 4.4. 
spectrum taken from the freshly fractured sample. Significant concentrations of $\mathrm{P}$ and $\mathrm{S}$ are indicated by peaks at 120 and $150 \mathrm{eV}$, respectively, in Fig. 4.5. The $I(P, 120 \mathrm{eV}) / I(R h, 302 \mathrm{eV})$ ratio in Fig. 4.5 is 0.12 , which suggests a $\mathrm{X}_{\mathrm{P}} / \mathrm{X}_{\mathrm{Rh}}$ ratio of about $0.20 . *$ The $152 \mathrm{-eV} \mathrm{S}$ and $150-\mathrm{eV}$ Pt peaks are overlapping in Fig. 4.5; the $I(S, 152 \mathrm{eV}) / \mathrm{I}(\mathrm{Rh}, 302 \mathrm{eV})$ ratio is estimated to be about 0.15 , which suggests a $\mathrm{X}_{\mathrm{S}} / \mathrm{X}_{\mathrm{Rh}}$ ratio of about 0.15 . Inert ion sputtering of the fracture surface for $2 \mathrm{~min}$, and subsequent reanalysis indicated that the S- and P-rich region is within a few atom layers of the grain boundary.

These results suggest that the brittleness of Pt-3008 after exposure to Fiberfrax insulation at $950^{\circ} \mathrm{C}$ may be due to contamination with $\mathrm{P}$ and/or S. Examination of a reference sample (having the same thermal history, but without contact with Fiberfrax) is planned in order to determine the source of the $\mathrm{P}$ and $\mathrm{S}$.

\subsection{Insulation Characterization}

G. C. Wei

The assessment of commercially available thermal insulation materials for the selenide generator was completed and is being reviewed for publication. Fibrous insulation materials which have the potential to be used as load-bearing or non-load-bearing thermal insulations were reviewed, and thermophysical properties supplied by manufacturers or published in the literature were presented. Major conclusions are summarized below:

1. Manufacturers' thermal conductivity data should only be used as a guideline.

2. Thermal conductivity must be measured in an environment simulating application conditions.

3. Compatibility between fibrous insulations and graphite, Pt-3008, and thermoelectric elements must be confirmed before the GDS tests.

4. Further work on fibrous insulation structural and microstructural changes at high temperatures for long-term operation is needed.

\footnotetext{
*See the discussion on $\mathrm{p} .39$ of this report concerning calculations of atom fraction ratios.
} 
5. Procedures of outgassing, forming, and installation of fibrous insulations are not fully established.

Several fibrous insulation materials were characterized with the aid of SEM and $x$ ray. The results of SEM and $x$-ray characterization on Cotronics 360 are summarized as follows:

1. An extraneous crystalline phase containing $\mathrm{Mg}, \mathrm{Ca}$, and $\mathrm{Si}$ is present and amounts to about 1 vol \%. It is expected that this will cause shrinkage and thus structural instability, which in turn, will tend to increase the thermal conductivity.

2. Impurities such as $\mathrm{Ca}, \mathrm{Mg}, \mathrm{Fe}, \mathrm{Ti}, \mathrm{Cu}$, In, Se, and $\mathrm{Mn}$ are present in appreciable amounts.

3. A large quantity of shot content is present and the shot is not distributed uniformly in the insulation.

The above findings suggest that Cotronics 360 is not a desirable fibrous insulating material for the heat source of the selenide generator.

Min-K TE-1400 consists of silica particles of 15- to 20-4m size. Minor concentration of $\mathrm{TiO}_{2}$ opacifier was detected. Silica glass fibers are used as structural reinforcement in Min-K TE-1400. Fiberfrax HiFi 660H paper is made up of amorphous alumina-silica fibers. Unfiberized shot is present in Fiberfrax HiFi $660 \mathrm{H}$. Kaowool 3000 is based on alumina fibers in which a slight amount of silica is also present. Binder phase consists of alumino-silicates. Unfiberized shot content is zero and the distribution of fiber diameter, length, and orientation is rather uniform in Kaowool 3000 . Zircar ZYFB3 consists of hafnium-stabilized zirconia fibers. Significant grain growth has occurred in each Zircar fiber, and fibers are present in the form of bundles. These observations indicate that these insulations may not be stable during long-term operation at high temperatures.

\subsection{References}

1. See section 1.3.1, "Pt-3008 Scale-Up and Fabrication Development," p. 13 of this report.

2. A. C. Schaffhauser, Isotopic Power Materials Development Quart. Progr. Rep. June 30, 1976, "Welding of Pt-3008," ORNL/TM-5569, p. 12. 


\section{ISOTOPE BRAYTON SYSTEM MATERTALS SUPPORT*}

\subsection{Introduction}

The objective of this program is to characterize the metallurgical and mechanical properties of materials and components selected for the Brayton Isotope Power System (BIPS) under the environmental and operating conditions expected for this system. Currently, emphasis is on the potential materials problems identified in the BIPS Ground Demonstration System (GDS), scheduled for operation in 1977. These potential materials problems include the effect of contaminants on the creep properties and tensile ductility of $\mathrm{C}-103(\mathrm{Nb}-10 \% \mathrm{Hf}-1 \% \mathrm{~T} \mathbf{i}-0.7 \% \mathrm{Zr})$ in the heat exchanger, ducting, and turbine plenum; effects of aging and thermal cycling on the properties of $\mathrm{C}-103$ / Hastelloy $\mathrm{X}$ bimetallic joints; and the mechanical properties of braze alloys used for fabrication of the Hastelloy $X$ recuperator. The magnitude of these potential materials problems and possible solutions are being investigated. Characterization of other key components including ducting and bellows will be performed. Additional tasks such as investigation of alternate materials and long-term creep tests will be initiated as required to insure the reliability of a flight system, scheduled for 1981.

\section{$5.2 \mathrm{C}-103$ Gaseous Interactions}

\subsubsection{Creep Properties of C-103 in Contaminating Environments - H. Inouye}

A C-103 sheet specimen has been creep tested under a sequence of controlled environmental and stress conditions to determine the effect of pyromellitic acid on its creep rate at $878^{\circ} \mathrm{C}$. Pyromellitic acid $\left(\mathrm{C}_{10} \mathrm{H}_{6} \mathrm{O}_{8}\right)$ is a principal compound outgassed from the alternator-stator at its operating temperature of $121^{\circ} \mathrm{C}$. As reported previously, ${ }^{1}$ this compound decomposes at the test temperature to $\mathrm{H}_{2} \mathrm{O}$ as the major gas species with smaller fractions of $\mathrm{CO}, \mathrm{CO}_{2}$, and $\mathrm{O}_{2}$.

\footnotetext{
*Progress on work performed under Activity No. KJ 070201 0, 189a No. 01319.
} 
The creep rates measured for $\mathrm{C}-103$ for several conditions are tabulated in Table 5.1. These data show that the creep rate of an uncontaminated specimen (condition A) in less than $10 \%$ of the rate measured in the $\mathrm{C}_{10} \mathrm{H}_{6} \mathrm{O}_{8}$ environment at $1.3 \times 10^{-3} \mathrm{~Pa}\left(10^{-5}\right.$ torr) (condition $\mathrm{B}$ ). Although it is believed that the strain measured for the test interval under the latter condition is caused mainly by dilation of the specimen during its contamination, we were unable to confirm this when the load was removed from specimen. Under no-load conditions (condition $C$ ), the creep rate for the 1230-1906 time interval was only $1.3 \times 10^{-4} \% / \mathrm{hr}$ and not the expected higher rate of approximately $4 \times 10^{-3} \% / \mathrm{hr}$; however, it was noted that on reapplying the load in a vacuum (condition $D$ ), the creep rate was near the expected dilation rate but only for $94 \mathrm{hr}$.

Table 5.1. Effect of $\mathrm{C}_{10} \mathrm{H}_{6} \mathrm{O}_{8}$ on the Creep Rate of $\mathrm{C}-103$ Stressed to $145 \mathrm{MPa}(21 \mathrm{ksi})$ at $878^{\circ} \mathrm{C}^{\mathrm{a}}$

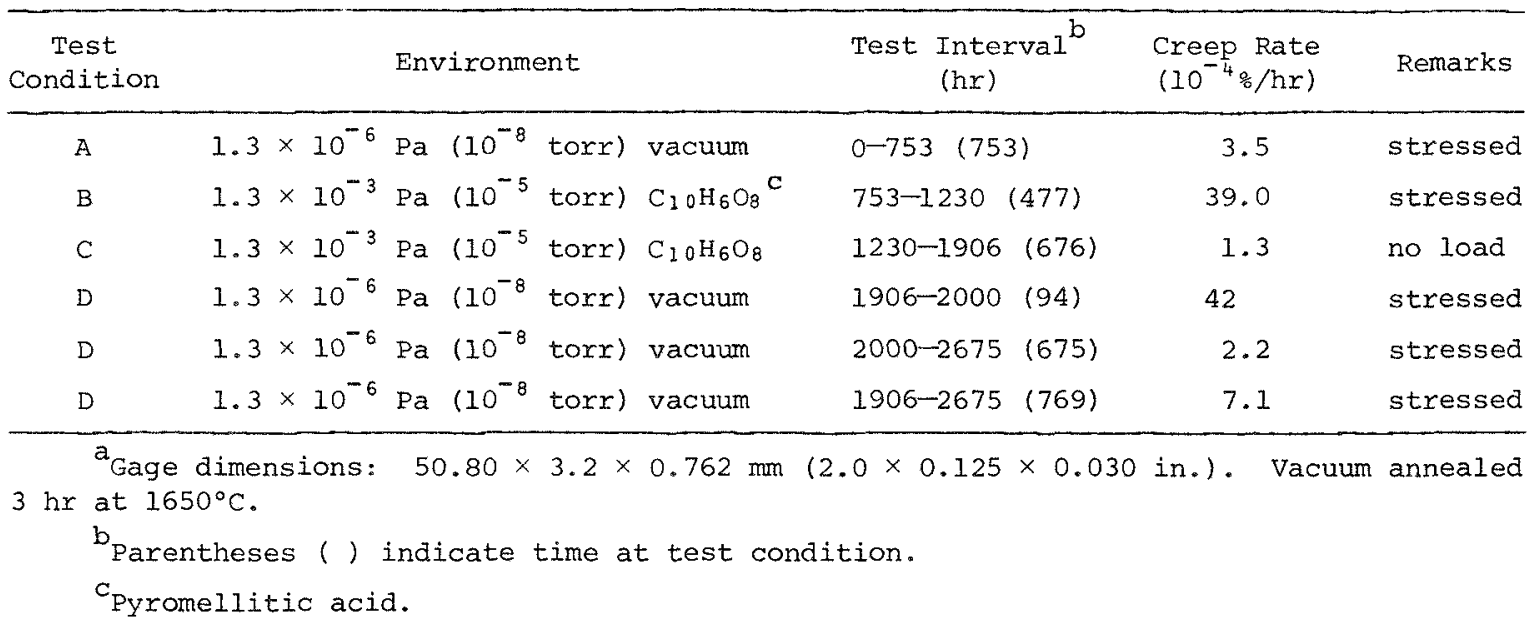

The strain-time curve for the specimen tested under the conditions outlined in Table 5.1 is shown in Fig. 5.1. Distinct breaks in the curve occur precisely at the time of each condition change. Since the sharp break in the curve observed when the load is removed at $1230 \mathrm{hr}$ is not consistent with prior dilation data, we assume that it was caused by some bending of the specimen when the load was removed, then, on reapplying the load at $1906 \mathrm{hr}$, the specimen straightened out over the next $94 \mathrm{hr}$. With this interpretation, the creep rate of the specimen of $2.2 \times 10^{-4} \% / \mathrm{hr}$ between 


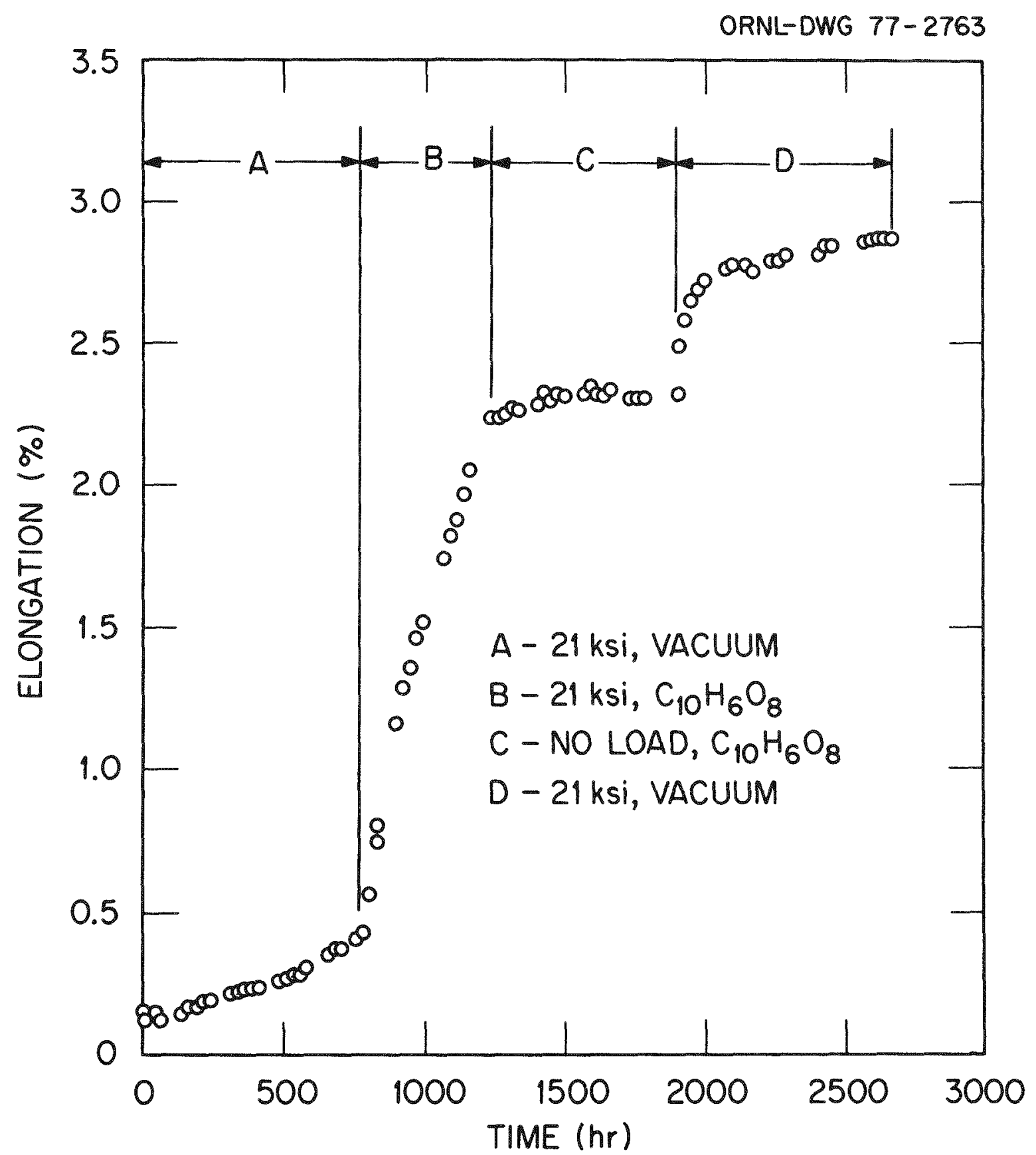

Fig. 5.1. Creep Curve for $\mathrm{C}-103$ at $878^{\circ} \mathrm{C}$ Under Various Environmental and Stress Conditions. 
2000-2675 hr represents the creep properties of a predoped C-103 specimen; and as the data in Table 5.1 indicates, is significantly stronger than an uncontaminated specimen where rate is $3.5 \times 10^{-4 \%} / \mathrm{hr}$. Another intrepretation of these data is that the synergistic effects of stress and contamination is greater than the sum of each of these factors alone. To resolve which of these interpretations is representative of the data, the creep test will be repeated but at a low stress.

\subsubsection{Kinetics of Gaseous Absorption in C-103 - C. T. Liu and H. Inouye}

To study the kinetics of gaseous absorption in $\mathrm{C}-103$, sheet specimens with a thickness of $0.80 \mathrm{~mm}(0.0315 \mathrm{in.})$ ( were vacuum annealed $1 \mathrm{hr}$ at $1650^{\circ} \mathrm{C}$ then exposed to carbon monoxide gas at a pressure of $1.3 \times 10^{-3} \mathrm{~Pa}\left(10^{-5}\right.$ torr) at 1000 and $850^{\circ} \mathrm{C}$. The specimens were periodically removed from the furnace and weighed.

The specimens showed no clear indication of surface film after exposure. The exposed specimens exhibited weight gains due to absorption of oxygen and carbon from the environment. Figure 5.2 shows the plot of the weight gain as a function of square root of exposure time $(t)$. The weight gain measured from tensile specimens [with a thickness of $0.64 \mathrm{~mm}(0.025$ in.)] exposed at $1.3 \times 10^{-3} \mathrm{~Pa}\left(10^{-5}\right.$ torr $) \mathrm{CO}$ at $850^{\circ} \mathrm{C}$ is also plotted as curve $\mathrm{C}$ in Fig. 5.2. The difference between curves $B$ and $C$ is due to thickness effect. As shown in the plot, the weight gain in C-103, after an incubation

period, increases linearly with $t^{1 / 2}$. This clearly indicates that a diffusion process controls the kinetics of carbon monoxide gas absorption in $\mathrm{C}-103$ at 850 and $1000^{\circ} \mathrm{C}$. Because of the diffusion control, the absorption rate decreases continuously with exposure time. After a 500-hr exposure to $1.3 \times 10^{-3} \mathrm{~Pa}\left(10^{-5}\right.$ torr $) \mathrm{CO}$, the $\mathrm{C}-103$ sheet specimens were contaminated at a rate of approximately $4.4 \mathrm{ppm} / \mathrm{hr}$ at $1000^{\circ} \mathrm{C}$ and approximately $1.8 \mathrm{ppm} / \mathrm{hr}$ at $850^{\circ} \mathrm{C}$.

\subsubsection{Tensile Properties of $\mathrm{C}-103$ in Contaminating Environments - C. T. Liu and $H$. Inouye}

To study the embrittlement effects of gaseous environments, tensile sheet specimens of $\mathrm{C}-103$ were vacuum annealed $1 \mathrm{hr}$ at $1650^{\circ} \mathrm{C}$ and then exposed to carbon monoxide gas at a pressure of $1.3 \times 10^{-3} \mathrm{~Pa}\left(10^{-5}\right.$ torr $)$ 


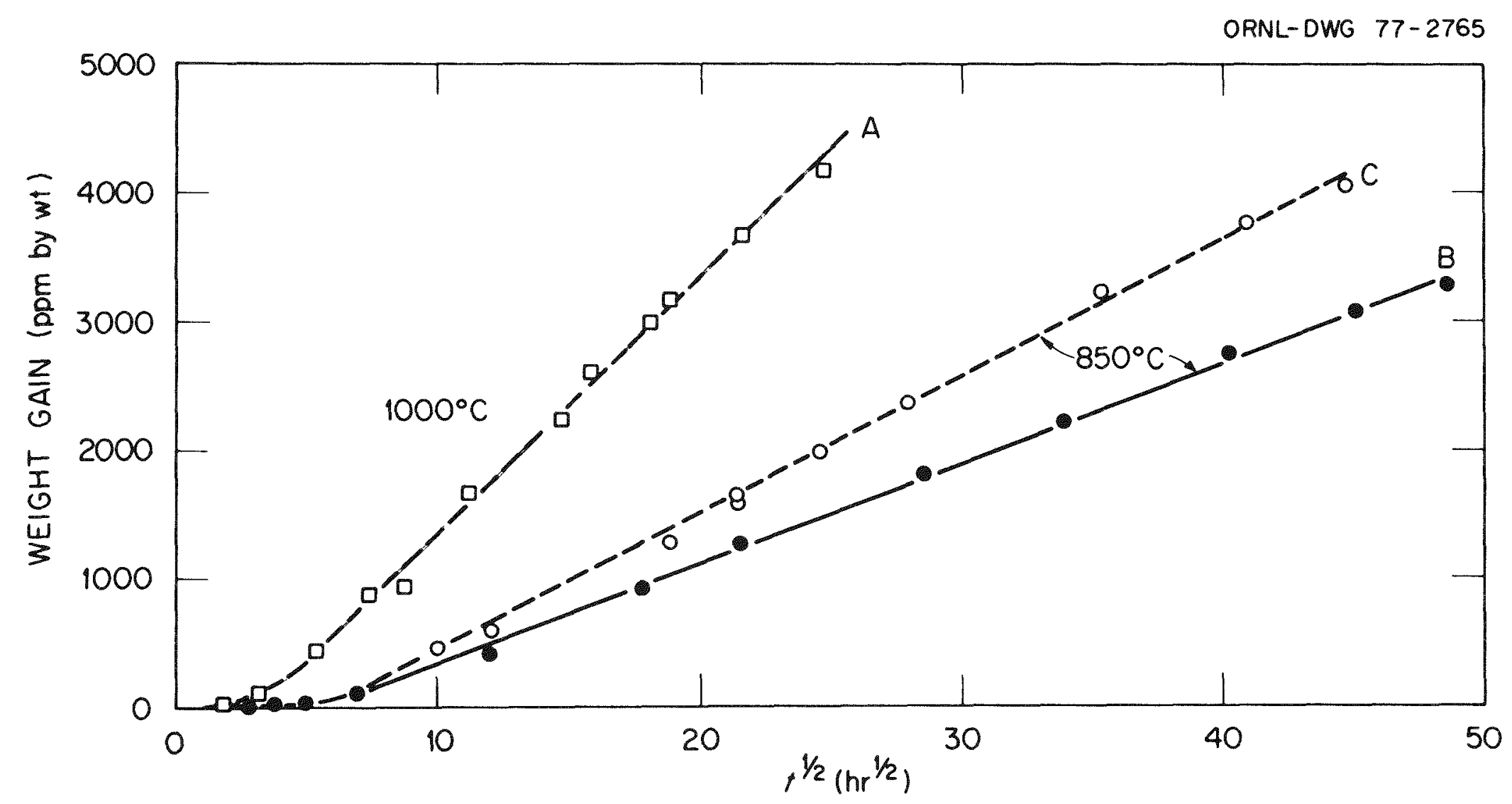

Fig. 5.2. Plot of Weight Gain in C-103 Specimens Exposed to $1.3 \times 10^{-3} \mathrm{~Pa}\left(10^{-5} \mathrm{Torr}\right) \mathrm{CO}$ as a Function of Square Root of Exposure Time $(t)$. Curve A: exposed at $1000^{\circ} \mathrm{C}$, specimen thickness: $0.8 \mathrm{~mm}(0.0315 \mathrm{in.})$; curve $\mathrm{B}$ : exposed at $800^{\circ} \mathrm{C}$, specimen thickness: $0.8 \mathrm{~mm}(0.0315$ in.); curve $\mathrm{C}$ : exposed at $850^{\circ} \mathrm{C}$, specimen thickness: $0.64 \mathrm{~mm}(0.025 \mathrm{in}$.$) .$ 
at 1000 and $850^{\circ} \mathrm{C}$. To date, specimens contaminated to a level of $4200 \mathrm{ppm}$ have been tested at room temperature, 800 and $1000^{\circ} \mathrm{C}$. The tensile elongation is plotted as a function of weight gain in Fig. 5.3. The specimens exposed to carbon monoxide at $1000^{\circ} \mathrm{C}$ showed a steady decrease in ductility with weight gain at all three test temperatures. In contrast, the ductility of the $850^{\circ} \mathrm{C}$-exposed specimens decreases sharply to a level of $1000 \mathrm{ppm}$, then increases slightly in the range $1000-3400 \mathrm{ppm}$, and finally decreases again beyond $3400 \mathrm{ppm}$. The C-103 specimens contaminated to $4200 \mathrm{ppm}$ at $850^{\circ} \mathrm{C}$ still had $3-5 \%$ elongation at room temperature and $850^{\circ} \mathrm{C}$.

Numerous cracks were observed in the surface of the tensile-fractured specimens contaminated with more than $1000 \mathrm{ppm}$. Examination of the fracture surface revealed that it generally consisted of two fractured regions, i.e., a ductile region in the center surrounded by brittle fracture at the rim. This observation also indicates an interstitial gradient with a higher level of contamination near the specimen surfaces.

\subsection{Welding and Brazing}

G. M. Goodwin and J. D. Hudson

We are testing lap-shear specimens of Hastelloy $X$ brazed to itself with Palniro 7 (Au-8\% Pd-22\% Ni) and Hastelloy $\mathrm{X}$ brazed to $\mathrm{C}-103$ alloy sheet using Coast Metals 50 ( $\mathrm{Ni}-3.5 \% \mathrm{Si}-2.5 \% \mathrm{~B}-1 \% \mathrm{Fe}$ ). Recent tensile tests are summarized in Table 5.2, with previously reported tests for comparison. Increasing strain rate by a factor of 10 (from 0.05 to $0.5 / \mathrm{min}$ ) appears to show somewhat higher strength and ductility in the Hastelloyto-Hastelloy brazes at $649^{\circ} \mathrm{C}$.

A repeat in argon of a test previously run in air showed improved strength and ductility for a Hastelloy-to-columbium alloy braze at $732^{\circ} \mathrm{C}$. Subsequent tests involving the $\mathrm{C}-103$ alloy at elevated temperatures will be performed in argon.

Braze specimens of both types have been aged $1000 \mathrm{hr}$ at $732^{\circ} \mathrm{C}$ in vacuum, and tensile tests of aged specimens are being performed at 20 and $732^{\circ} \mathrm{C}$. 


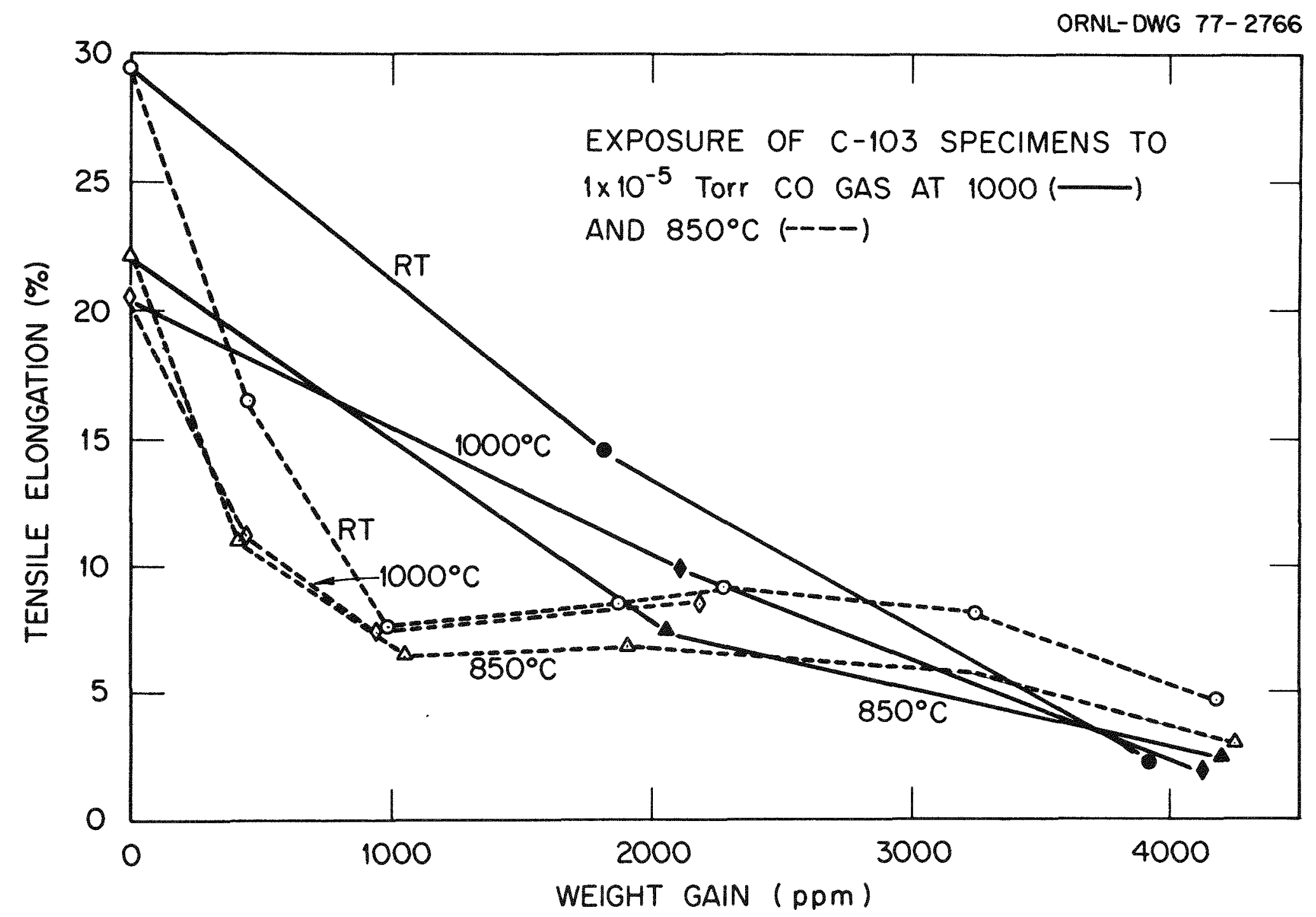

Fig. 5.3. Plot of Tensile Elongation as a Function of Weight Gain for C-103 Specimens Exposed to Carbon Monoxide Gas at 1000 (Filled Symbols) and $850^{\circ} \mathrm{C}$ (Open Symbols). 
Table 5.2. Tensile Properties of Hastelloy $X$ and Hastelloy $X$ to $\mathrm{C}-103$ Alloy Brazements ${ }^{a}$

\begin{tabular}{|c|c|c|c|c|c|}
\hline $\begin{array}{c}\text { Specimen } \\
\text { Designation }\end{array}$ & $\begin{array}{l}\text { Specimen } \\
\text { Type }\end{array}$ & $\begin{array}{c}\text { Test } \\
\text { Temperature } \\
\left({ }^{\circ} \mathrm{C}\right)\end{array}$ & $\begin{array}{l}\text { Ultimate } \\
\text { Strength } \\
\mathrm{MPa}(\mathrm{ksi})\end{array}$ & $\begin{array}{l}\text { Total } \\
\text { Elongation } \\
(\%)\end{array}$ & $\begin{array}{l}\text { Fracture } \\
\text { Location }\end{array}$ \\
\hline $\mathrm{H}-3$ & $\mathrm{H} / \mathrm{H}$ & 649 & $148.1(21.5)$ & 4.5 & Braze \\
\hline $\mathrm{H}-8$ & $\mathrm{H} / \mathrm{H}-\mathrm{Fast}$ & 649 & $184.8(26.8)$ & 6.7 & Braze \\
\hline $\mathrm{HC}-1$ & $\mathrm{H} / \mathrm{C}$ & 732 & $91.0(13.2)$ & 4.0 & Braze \\
\hline$H C-1-R^{b}$ & $\mathrm{H} / \mathrm{C}$ & 732 & $129.3(18.8)$ & 6.9 & Braze \\
\hline \multicolumn{6}{|c|}{$\begin{array}{l}\mathrm{a}_{\text {Lap-shear specimens of } 3.2-\mathrm{mm}(0.125-\mathrm{in} .)} \text { Hastelloy sheet brazed to } \\
\text { lf with Palniro } 7 \text { alloy ( } \mathrm{Au}-8 \% \mathrm{Pd}-22 \% \mathrm{Ni}) \text { and to } 2-\mathrm{mm}(0.080-\mathrm{in} .) \\
3 \text { alloy sheet with Coast Metals } 50 \text { alloy (Ni-3.5\% Si-2.5\% B-1\% Fe), } \\
\text { ed at strain rate of } 0.05 / \text { min in air. }\end{array}$} \\
\hline
\end{tabular}

\subsection{Reference}

1. A. C. Schaffhauser, Isotopic Power Materials DeveZopment Quart. Progr. Rep. Sept. 30, 1976, ORNL/TM-5810. 


\section{SPACE NUCLEAR FLIGHT SYSTEMS HARDWARE*}

\subsection{Introduction}

The limited-scale production of high-quality iridium alloy sheet and foil, based on ORNL-developed procedures, is performed in this task. Forming disks are machined from sheet and are supplied to Mound Laboratory for hot hydroforming into hemispheres which encapsulate the ${ }^{238} \mathrm{PuO}_{2}$ isotope fuel spheres and serve as the Post-Impact Containment Shells (PICS) of the Multi-Hundred Watt (MHW) Heat Source. Iridium alloy foil is also supplied for forming weld shields and decontamination covers during processing the PICS. Extensive quality assurance and characterization of material, along with a limited amount of process improvement development, is performed in this task.

\subsection{Production of $\operatorname{Ir}-0.3 \% \mathrm{~W}$ Forming Disks and Foil \\ D. E. Harasyn}

Production data on Ir-0.3\% $\mathrm{W}$ forming disks shipped in October, November, and December of 1976 are shown in Table 6.1. In January 1977, two more shipments will be made to MRC to complete the forming disk requirement for the SIPS project.

Approximately $2060 \mathrm{~cm}^{2}\left(320 \mathrm{in.}^{2}\right)$ of $0.25-\mathrm{mm}-(0.010-\mathrm{in.-})$ thick and $2510 \mathrm{~cm}^{2}$ (390 in. ${ }^{2}$ ) of $0.13-\mathrm{mm}-(0.005-\mathrm{in.-})$ thick Ir $-0.3 \% \mathrm{~W}$ foil has been shipped to Battelle Columbus Laboratories for vent experiments.

\subsection{Grain Growth in Ir-0.3\% W Alloys \\ D. E. Harasyn}

In a recent monthly report from LASL, ${ }^{1}$ very large grains were observed in fueled and impacted PICS made from DOP-4 Ir $-0.3 \% \mathrm{~W}$. MHFT-56 had 2-5 grains across the wall. MHFT-55 also had large grains near the inside of the she11, but appeared to have smaller grains near the exterior of the

*Progress on work performed under Activity No. KJ 070300 0, 189a No. 01322 . 
Table 6.1. PICS Production Data

\begin{tabular}{|c|c|c|c|c|c|c|c|c|c|c|c|c|}
\hline \multirow{3}{*}{$\begin{array}{l}\text { Ingot } \\
\text { Number }\end{array}$} & \multirow{3}{*}{$\begin{array}{c}\text { Number } \\
\text { Machined }\end{array}$} & \multicolumn{4}{|c|}{ Nonconformance Report ${ }^{a}$} & \multirow{2}{*}{\multicolumn{2}{|c|}{ Disks }} & \multirow{2}{*}{\multicolumn{2}{|c|}{ hipped }} & \multicolumn{2}{|c|}{ Total Shipped } & \multirow{3}{*}{$\begin{array}{l}\text { Date } \\
\text { Shipped }\end{array}$} \\
\hline & & \multicolumn{4}{|c|}{ Disk Number } & & & & & & Cumulative & \\
\hline & & 1 & 2 & 3 & 4 & & & & & Lot & for Quarter & \\
\hline$T R-512$ & 4 & & & & & 1 & 1 & 1 & 1 & & & $10 / 6 / 76$ \\
\hline-513 & 2 & & & & & 1 & 1 & & & & & $10 / 6 / 76$ \\
\hline-514 & 4 & & & & & 1 & $\overline{1}$ & 1 & 1 & & & $10 / 6 / 76$ \\
\hline-515 & 4 & & & $P$ & & 1 & 1 & & 1 & & & $10 / 6 / 76$ \\
\hline-516 & 4 & & & & & $I$ & 1 & 1 & 1 & & & $10 / 6 / 76$ \\
\hline-517 & 4 & & & & & 1 & 1 & 1 & 1 & $24^{b}$ & 24 & $10 / 6 / 76$ \\
\hline-518 & 4 & & & & & 1 & 1 & 1 & 1 & & & $10 / 26 / 76$ \\
\hline-519 & 4 & & & & $\mathrm{U}$ & 1 & 1 & 1 & & & & $10 / 26 / 76$ \\
\hline-520 & 4 & & & & $\mathrm{U}$ & 1 & 1 & 1 & & & & $10 / 26 / 76$ \\
\hline-521 & 4 & & & & & 1 & 1 & 1 & 1 & & & $10 / 26 / 76$ \\
\hline-522 & 4 & & & $U$ & & 1 & 1 & & 1 & & & $10 / 26 / 76$ \\
\hline-523 & 4 & & & & & 1 & 1 & $I$ & 1 & $22^{\mathrm{C}}$ & 46 & $10 / 26 / 76$ \\
\hline-524 & 4 & $P$ & & & & & 1 & 1 & 1 & & & $11 / 12 / 76$ \\
\hline-525 & 4 & & & & & 1 & 1 & 1 & 1 & & & $11 / 12 / 76$ \\
\hline-526 & 4 & $\mathrm{P}$ & & $P$ & & & 1 & & 1 & & & $11 / 12 / 76$ \\
\hline-527 & 4 & & U & & & 1 & & 1 & 1 & & & $11 / 12 / 76$ \\
\hline-528 & 4 & & & $P$ & $\mathrm{U}$ & 1 & 1 & & & & & $11 / 12 / 76$ \\
\hline-529 & 4 & U & & D & $D$ & & 1 & 1 & 1 & & & $11 / 12 / 76$ \\
\hline Reject & $\operatorname{Lot}^{d}$ & & & & & & & & & $\begin{array}{l}17 \\
38\end{array}$ & $\begin{array}{r}63 \\
101\end{array}$ & $12 / 6 / 76$ \\
\hline$T R-530$ & 4 & $U$ & & & & & 1 & 1 & 1 & & & $12 / 20 / 76$ \\
\hline-531 & 4 & & & & & 1 & 1 & 1 & 1 & & & $12 / 20 / 76$ \\
\hline-532 & 4 & & & & & 1 & 1 & 1 & 1 & & & $12 / 20 / 76$ \\
\hline-533 & 4 & & & & & 1 & 1 & 1 & 1 & & & $12 / 20 / 76$ \\
\hline-534 & 4 & & & & & 1 & 1 & 1 & 1 & & & $12 / 20 / 76$ \\
\hline-535 & 4 & & $U$ & & & 1 & & 1 & 1 & $25^{e}$ & 1.26 & $12 / 20 / 76$ \\
\hline
\end{tabular}

\footnotetext{
$\mathrm{a}_{\mathrm{P}}=$ dye penetrant; $\mathrm{U}=$ ultrasonic; and $\mathrm{D}=$ dimensional.
}

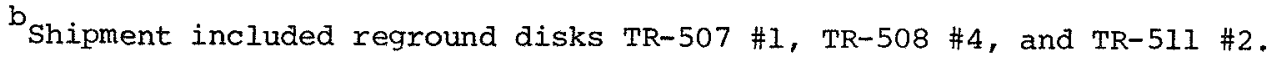

Shipment included reground disk TR-515 \#3.

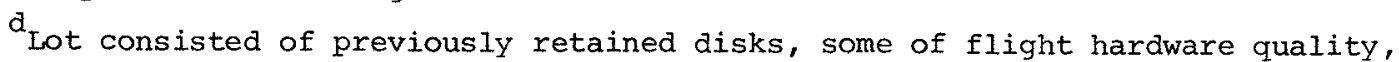
many with minor defects.

eshipment included reground disks $T R-526 \# I$ and $\# 3$, and $T R-528 \# 3$. 
she11. MHFT-55 had 3-12 grains across the wall. The heat treatment of these PICS in contact with $\mathrm{PuO}_{2}$ fuel was 32 days at $1330^{\circ} \mathrm{C}$ plus 200 sec at $1550^{\circ} \mathrm{C}$ plus $1 \mathrm{hr}$ at $1440^{\circ} \mathrm{C}$. Since MHFT tests are made on fuel spheres taken from the MRC production line, MHFT-55 and -56 received processing heat treatments of $1 \mathrm{hr}$ at $1175^{\circ} \mathrm{C}$ and $1 \mathrm{hr}$ at $1500^{\circ} \mathrm{C}$ prior to heat treatment at LASL. At ORNL, we duplicated the LASL aging treatments in vacuum without the fuel using the same lot of iridium as in the MHFT tests (HD 403-408). The MRC heat treatments of $\mathrm{I} \mathrm{hr}$ at 1175 and $1500^{\circ} \mathrm{C}$ were omitted, but their effect on grain growth was calculated from previous data. Doped (HD-405, DOP-4-4) and undoped (WG-202) Ir $0.3 \% \mathrm{~W}$ samples were taken from flat sheet stock and annealed in an iridium boat. The results shown in Table 6.2 are consistent with previous grain growth data obtained at ORNL. ${ }^{2}$ Had our samples received the 1 -hr heat treatment at $1500^{\circ} \mathrm{C}$ prior to the complex heat treatment, the calculated number of grains across the thickness would be 5.9 for WG and 12.9 for DOP-4. Very 1ittle data has been published on grain growth in Ir $-0.3 \% \mathrm{~W}$ after it is hydroformed into hemishells. However, it is unlikely that the forming process significantly changes grain growth in the alloy since the forming is done while the material is in a fibrous cold-worked condition. Three data points are available from a report by Frank et al. ${ }^{3}$ on hydroformed WC (undoped) material $\left(1500^{\circ} \mathrm{C} ; 1,6,18 \mathrm{hr}\right)$. These three

Table 6.2. Comparison of Grain Sizes for Ir-0.3\% W Samp1es Exposed to High Temperatures ${ }^{a}$

\begin{tabular}{|c|c|c|c|}
\hline \multirow[t]{2}{*}{$\begin{array}{c}\text { Alloy } \\
\text { Designation }\end{array}$} & \multirow[t]{2}{*}{$\begin{array}{l}\text { Ingot } \\
\text { Number }\end{array}$} & \multicolumn{2}{|c|}{$\begin{array}{c}\text { Number of Grains Across } \\
\text { a } 0.64-\mathrm{mm}(0.025-\mathrm{in} .) \\
\text { Thickness }\end{array}$} \\
\hline & & Observed & Calculated ${ }^{\mathrm{b}}$ \\
\hline $\mathrm{Ir}-0.3 \% \mathrm{~W}$ & WG-202 & 6.8 & 6.4 \\
\hline DOP-4 & $\mathrm{HD}-405$ & 13.2 & - \\
\hline DOP-4 & DOP $-4-4$ & 13.4 & 14.7 \\
\hline $\begin{array}{r}{ }^{\mathrm{a}_{\text {Heated }}} \\
1550^{\circ} \mathrm{C} \text { plus } \\
{ }_{\mathrm{b}} \mathrm{Calcul} \\
\text { in Ir-0.3\% } \\
\text { and A. C. Sc }\end{array}$ & $\begin{array}{l}68 \text { hr at } \\
\text { hr at } 14 \\
\text { ed from } \\
\text { lloys, or }\end{array}$ & $\begin{array}{l}0^{\circ} \mathrm{C} \text { plus } \\
\text { in vacuu } \\
\text { given in } \\
5233 \text {, by }\end{array}$ & $\begin{array}{l}\text { sec at } \\
\text { ain Growth } \\
\text { E. Harasyn }\end{array}$ \\
\hline
\end{tabular}


points agree we11 with data obtained at ORNL on flat sheet materials. As yet, no satisfactory explanation has been given to explain the discrepancy between ORNL grain size data and MHFT-55 and -56 .

Some representative microstructures from the DOP $-4 \mathrm{Ir}-0.3 \% \mathrm{~W}$ cladding of fuel simulant impact spheres MHT-103 and -104 are shown in Fig. 6.1. Nothing unusual was observed in the microstructures of the base metal. The spotty appearance of the weld zone contrasts with the clean microstructure of the base metal. The spots are thought to be etch pits.

Grain size data on MHT-103 and -104 are given in Table 6.3 along with data on DOP-4 production material which was annealed in vacuum at $1500^{\circ} \mathrm{C}$ for $19 \mathrm{hr}$. MHT-103 and -104 were annealed at General Electric Company $18 \mathrm{hr}$ at $1500^{\circ} \mathrm{C}$, loaded with $\mathrm{ThO}_{2}$ fuel simulant, and then annealed one more hour at $1500^{\circ} \mathrm{C}$. Although the grain size of the MHT samples are slightly smaller than those of the other DOP-4 samples, the difference is not considered significant.

\subsection{Impact Properties of Production Material}

$$
\text { C. T. Liu }
$$

We continue to qualify the impact properties of DoP-4-type $\mathrm{Ir}-0.3 \% \mathrm{~W}$ production material used for space nuclear flight systems hardware. Sheet specimens of heats $\mathrm{HD}-421,-446, \mathrm{HDR}-469$, and $\mathrm{TR}-500$, heat treated $19 \mathrm{hr}$ at $1500^{\circ} \mathrm{C}$, then impacted at a standard condition of $85 \mathrm{~m} / \mathrm{sec}(280 \mathrm{fps})$ and $1350^{\circ} \mathrm{C}$. The impact results are presented in Table 6.4 together with those obtained previously from different lots of production material. The grain size of the impacted specimens was measured and is also reported in Table 6.4. The preparation of these materials is described in the footnotes of this table. The impact properties and grain size of heats HD-421, -446 , and HDR-469 are not different from the other DOP-4 production 1ots. However, lot TR-500 had coarser grain structure and lower impact ductility as compared with the HD lots.

The impact elongation of production materials WGD, HD, and TR is plotted as a function of grain size in Fig. 6.2. The data are quite scattered in the plot; however, a general trend is still evident; that is, the impact ductility decreases with increasing grain size. 


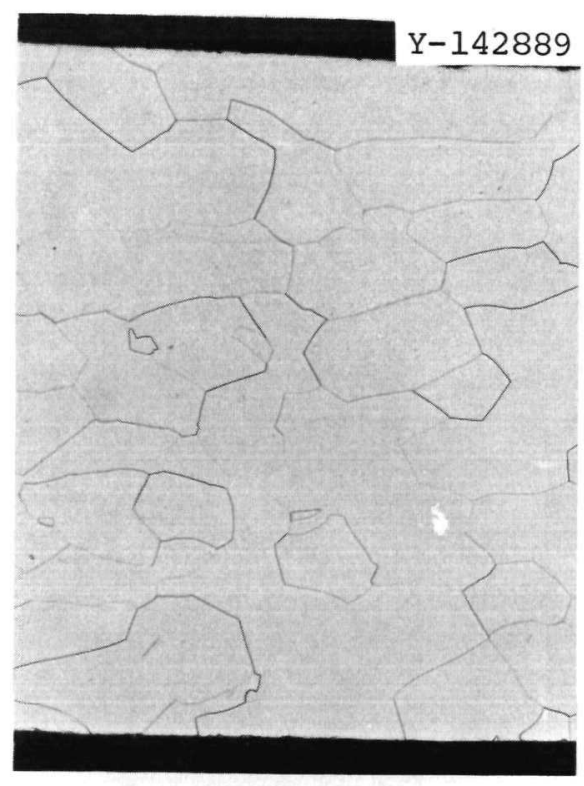

Base Metal

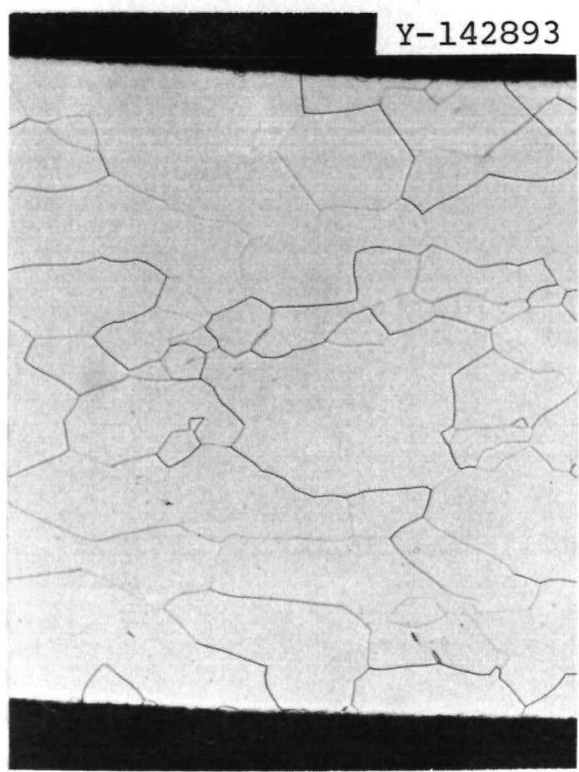

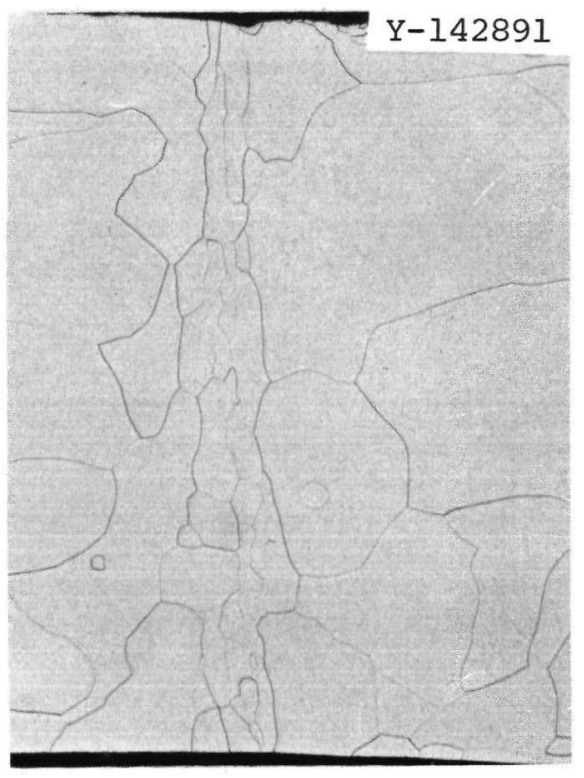

WELD ZONE

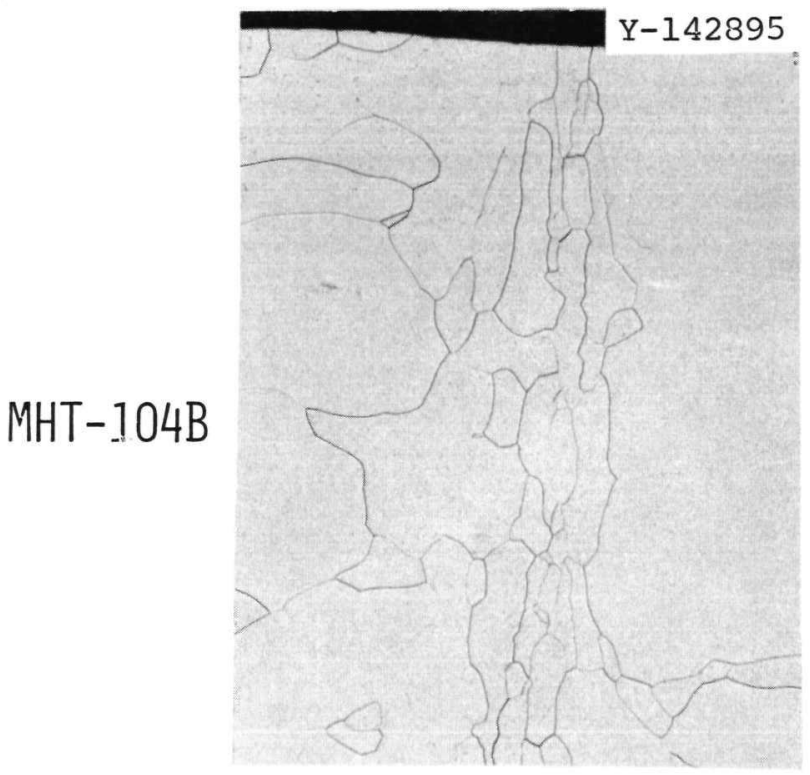

Fig. 6.1. Microstructures of MHT-103B and -104B. 100x. 
Table 6.3. Grain Size of MHT-103B and $-104 \mathrm{~B}$ as Compared to Various DOP-4 Production Samples ${ }^{\text {a }}$

\begin{tabular}{|c|c|}
\hline $\begin{array}{l}\text { Sample } \\
\text { Number }\end{array}$ & $\begin{array}{c}\text { Average Number of Grains Across } \\
\text { a } 0.064-\mathrm{cm}(0.025-\mathrm{in} .) \\
\text { Thickness }\end{array}$ \\
\hline MHT-103B & 11.7 \\
\hline$-104 B$ & 11.9 \\
\hline $\mathrm{HD}-400$ & 13.0 \\
\hline-403 & 9.1 \\
\hline-404 & 10.1 \\
\hline-406 & 10.3 \\
\hline-408 & 10.3 \\
\hline-412 & 10.9 \\
\hline-416 & 8.9 \\
\hline-424 & 9.0 \\
\hline-428 & 10.3 \\
\hline-436 & 10.4 \\
\hline-440 & 10.0 \\
\hline-459 & $9 . I_{b}$ \\
\hline $\mathrm{HD}$ average & $10.1^{b}$ \\
\hline WGD-266 & 7.8 \\
\hline-271 & 9.4 \\
\hline-274 & 8.4 \\
\hline-279 & 9.3 \\
\hline-290 & $10.0_{h}$ \\
\hline WGD average & $9.0^{b}$ \\
\hline \multicolumn{2}{|c|}{$\begin{array}{l}\mathrm{a}_{\mathrm{All}} \text { samples annealed } 19 \mathrm{hr} \text { at } 1500^{\circ} \mathrm{C} \\
\text { acuum except MHT-103B and }-104 \mathrm{~B} \text { which } \\
\text { as-received from Mound Laboratory. } \\
\mathrm{b}_{\text {Standard deviation of the average }} \\
2 \text {. }\end{array}$} \\
\hline
\end{tabular}


Table 6.4. Tensile Impact Properties of Ir $-0.3 \% \mathrm{~W}$ Alloy Sheet Annealed $19 \mathrm{hr}$ at $1500^{\circ} \mathrm{C}$ and Tested at $85 \mathrm{~m} / \mathrm{sec}(280 \mathrm{fps})$ at $1350^{\circ} \mathrm{C}$

\begin{tabular}{|c|c|c|c|c|c|}
\hline $\begin{array}{c}\text { Heat } \\
\text { Number }\end{array}$ & $\begin{array}{l}\text { Grain } \\
\text { Size }\end{array}$ & $\begin{array}{l}\text { Elongation } \\
\left(\frac{\circ}{8}\right)\end{array}$ & $\begin{array}{c}\text { Reduction } \\
\text { of Area } \\
(\%)\end{array}$ & Fracture & Mode ${ }^{b}$ \\
\hline$W C-65^{C}$ & 3.4 & 9.6 & 21 & Mainly GBS & \\
\hline$W G-204^{C}$ & 3.8 & 10.7 & 23 & MainIy GBS & \\
\hline DOP-4-1 ${ }^{d}$ & 9.9 & 26.8 & 60 & $T E$ and $D R$ & \\
\hline$W G D-271^{e}$ & 8.4 & 18.2 & 45 & TF (Ma) and & GBS (Mi) \\
\hline$H D-400^{I}$ & 10.3 & 21.1 & 52 & Mainly TF & \\
\hline $\mathrm{HD}-403^{9}$ & 8.6 & 20.8 & 50 & Mainly $T F$ & \\
\hline $\mathrm{HD}-411^{9}$ & 9.0 & 18.8 & 49 & $\mathrm{TF}$ (Ma) and & GBS (Mi) \\
\hline $\mathrm{HD}-416^{9}$ & 8.0 & 18.1 & 45 & TF (Ma) and & GBS (Mi) \\
\hline$H D-416^{9}$ & 7.3 & 14.8 & 36 & $\mathrm{TF}$ and GBS & \\
\hline$H D-421^{9}$ & 10.2 & 21.6 & 41 & $\mathrm{TF}$ (Ma) and & GBS (Mi) \\
\hline $\mathrm{HD}-428^{\mathrm{g}}$ & 8.9 & 15.2 & 39 & $\mathrm{TF}$ and GBS & \\
\hline $\mathrm{HD}-428^{9}$ & 8.3 & 16.5 & 42 & $\mathrm{TF}$ (Ma) and & GBS (Mi) \\
\hline $\mathrm{HD}-436^{\mathrm{g}}$ & 8.1 & 18.5 & 46 & $T F$ (Ma) and & GBS (Mi) \\
\hline $\mathrm{HD}-440^{9}$ & 11.7 & 20.5 & 59 & Mainly TF & \\
\hline $\mathrm{HD}-446^{\mathrm{g}}$ & 8.9 & 20.9 & 50 & $\mathrm{TF}$ (Ma) and & GBS (Mi) \\
\hline $\mathrm{HD}-459^{9}$ & 10.7 & 18.9 & 57 & Mainly $\mathrm{TF}$ & \\
\hline $\mathrm{HDR}-469^{h}$ & 9.6 & 23.2 & 57 & Mainly $T F$ & \\
\hline$T R-500^{i}$ & 6.2 & 15.2 & 44 & $\mathrm{TF}$ and $\mathrm{GBS}$ & \\
\hline
\end{tabular}

${ }^{a}$ Number of grains across a $0.64-m m-(0.025-i n .-)$ sheet thickness.

$\mathrm{b}_{\mathrm{GBS}}=$ grain-boundary separation; $\mathrm{TR}=$ transgranular fracture;

$\mathrm{DR}=$ ductile rupture; $\mathrm{Ma}=$ major fraction; and $\mathrm{Mi}=$ minor fraction.

$C_{\text {Undoped }}$ Ir $-0.3 \% \mathrm{~W}$ alloys.

$\mathrm{d}_{\text {Ir }-0.3 \%} \mathrm{~W}$ alloy doped with DOP-4 dopants, produced from electronbeam melting of WG powder compacts.

Ir-0.3\% W alloy doped with DOP-4 dopants, produced from electronbeam melting of $40 \%$ WG powder compacts and $60 \%$ WG recycled skulls and heads.

$f_{\text {Ir }} 0.3 \%$ W alloy doped with DOP-4 dopants, produced from electronbeam melting of HD powder compacts.

${ }^{9}$ Ir-0.3\% w alloy doped with Dop-4 dopants, produced from electronbeam melting of $40 \% \mathrm{HD}$ powder compacts and $60 \% \mathrm{HD}$ recycled skulls and heads.

$h_{\text {I } x}-0.3 \% \mathrm{w}$ alloy doped with DOP-4 dopants, produced from 100\% HD recycled skulls and heads.

${ }^{i}$ Ir $-0.3 \% \mathrm{~W}$ alloy doped with $30 \mathrm{ppm}$ Th, produced from WA and WF scraps. 


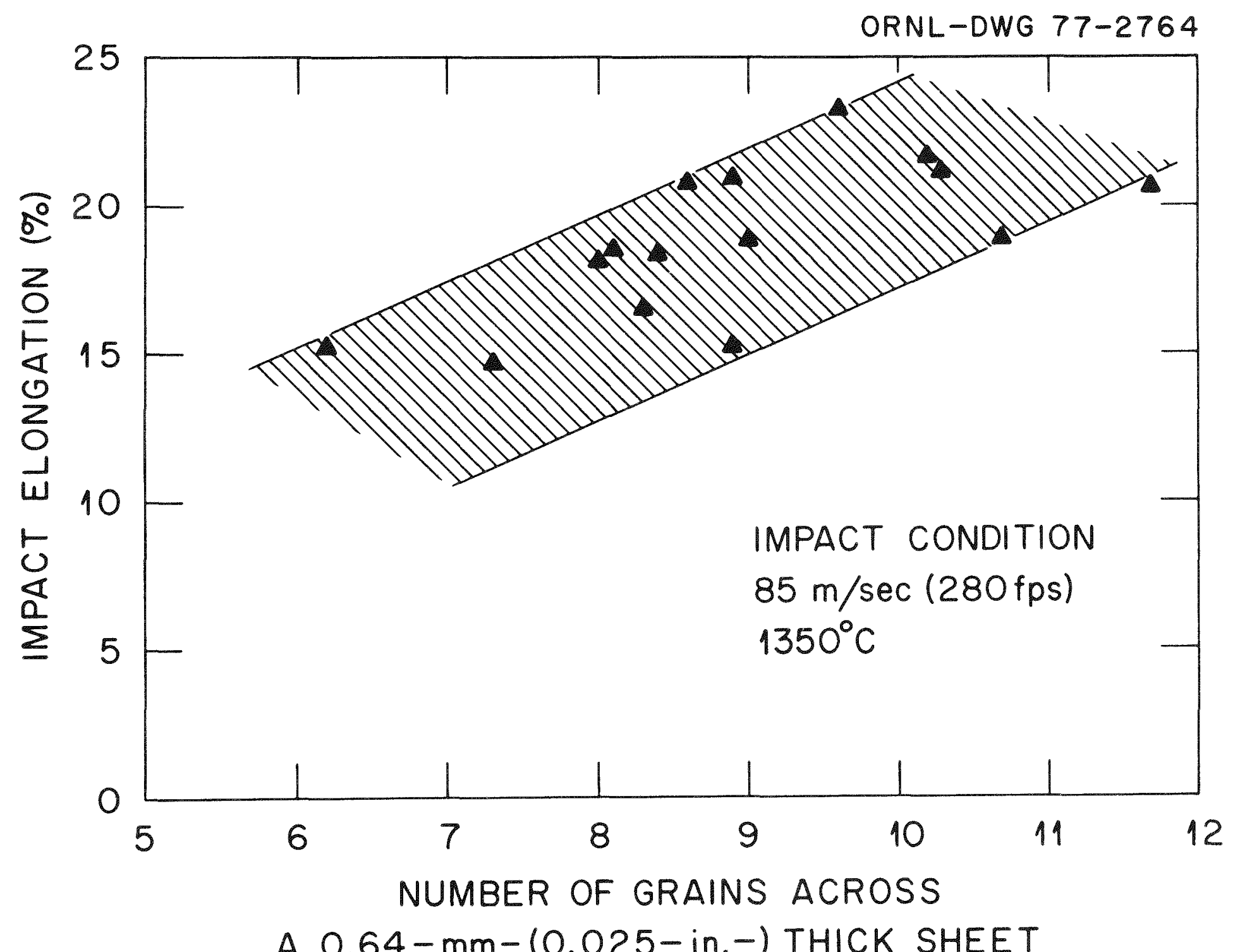

Fig. 6.2. Plot of Impact Elongation as a Function of Grain Size for Production Materials HD, TR, and WGD. 


\subsection{References}

1. R. D. Baker, Pu-238 Fuel DeveZopment Program, the Space Nuclear Safety Program, and the Radioisotopic Terrestrial Safety Program Monthly Report for August 1976, CMB-2320, p. 21.

2. D. E. Harasyn and A. C. Schaffhauser, Grain Growth in Ir-0.3\% W AZZoys, ORNL-5233 (January 1977), pp. 8-11.

3. R. G. Frank, A. C. Schaffhauser, W. Wyder, Backup Iridium Hemisphere Program Task Force Report, General Electric Space Division, GESP-744 (April 19, 1974), pp. 37-54. 
Blank 
ORNL/TM-5882

INTERNAL DISTRIBUTION

$\begin{array}{ll}\text { 1. } & \text { C. R. Brinkman } \\ \text { 2. } & \text { F. N. Case } \\ \text { 3. J. A. Carter } \\ \text { 4. R. E. Clausing } \\ \text { 5. J. E. Cunningham } \\ \text { 6. J. H. DeVan } \\ \text { 7. J. R. DiStefano } \\ \text { 8. R. G. Donnelly } \\ \text { 9. J. I. Federer } \\ \text { 10. G. M. Goodwin } \\ \text { 11. J. P. Hammond } \\ \text { 12. D. E. Harasyn } \\ \text { 13. R. L. Heestand } \\ \text { 14. M. R. Hill } \\ \text { 15. H. Inouye } \\ \text { 16. J. R. Keiser } \\ \text { 17. E. Lamb } \\ \text { 18. C. T. Liu } \\ \text { 19. W. R. Martin }\end{array}$

20. H. E. McCoy

21. R. E. McDonald

22. C. L. Ottinger

23. P. Patriarca

24. H. Postma

25-29. A. C. Schaffhauser

30. G. M. Slaughter

31. J. 0. Stiegler

32. V. J. Tennery

33. D. B. Trauger

34. G. C. Wei

35. J. R. Weir, Jr.

36. C. L. White

37. R. 0. Williams

38-39. Central Research Library

40. Document Reference Section

41-45. Laboratory Records

46. Laboratory Records, ORNL RC

47. ORNL Patent Office

\section{EXTERNAL DISTRIBUTION}

48-49. AiResearch Manufacturing Company of Arizona, 402 South 36th Street, P.0. Box 5217, Phoenix, AZ 85010
J. R. Hadley
J. E. McCormick

50-51. Battelle Memorial Institute, 505 King Avenue, Columbus, OH 43201
C. Alexander
W. Pardue

52. Battelle's Pacific Northwest Laboratories, Battelle Blvd, Richland, WA 99352

H. Fullam

53. Cabot Corporation, Stellite Division, 1020 Park Avenue, Kokomo, IN 46901

J. Tackett

54. Engelhard Industries, 700 Blair Road, Carteret, NJ 07008

H. J. Albert 
55. ERDA Dayton Area Office, P.O. Box 66, Miamisburg, OH 45342

J. A. Chacon

56-66. ERDA Division of Nuclear Research and Applications, Washington, DC 20545
T. J. Dobry
G. A. Newby
T. J. Holleman
B. J. Rock
W. D. Kenney
C. O. Tarr
A. P. Litman
N. R. Thielke
J. J. Lombardo
E. J. Wahlquist
A. L. Mowery

67. ERDA Division of Reactor Reserach and Development, Washington, DC 20545

J. M. Simmons

68. ERDA Dak Ridge Operations Office, P.O. Box E, Oak Ridge, TN 37830 Research and Technical Support Division

69. ERDA Office of Program Coordination and Management - Reactors and Space, 1333 Broadway, Oakland, CA 94612

W. L. Von Flue

70. ERDA Savannah River Operations Office, P.O. Box A, Aiken, SC 29801

L. M. East

71-97. ERDA Technical Information Center, Office of Information Services, P.0. Box 62, Oak Ridge, TN 37830

98. Fairchild Space and Electronics Company, Germantown, MD 20767

A. Schock

99. General Electric Company, Materials Technology, Energy Systems Programs, I River Road, Schenectady, NY 12345

R. G. Frank

100. Genera1 Electric Company, Nuclear Programs, P.0. Box 8661, Philadelphia, PA 19101

E. W. Williams

101. Gulf Energy and Environmental Systems, P.0. Box 608, San Diego, CA 92112

N. Elsner

102. Kirtland Air Force Base, NM 87117

Directorate of Nuclear Safety 
103-105. Los Alamos Scientific Laboratory, P.0. Box 1663, Los Alamos, NM 87545

R. D. Baker

S. E. Bronisz

S. S. Hecker

106. Minnesota Mining and Manufacturing Company, 2501 Hudson Road, St. Paul, MN 55119

E. F. Hampl

107-108. Monsanto Research Corporation, P.0. Box 32, Miamisburg, OH 45342

W. T. Cave/D. P. Kelly

E. W. Johnson/D. L. Coffey

109. NASA Headquarters, Washington, DC 20546

T. B. Kerr

110. NASA Jet Propulsion Laboratory, California Institute of Technology, 4800 Oak Grove Drive, Pasadena, CA 91103

V. Truscello

111-112. NASA Lewis Research Center, 2100 Brookpark Road, Cleveland, OH 44135

M. Ault

W. D. Klopp

R. Migra

113-114. Savannah River Laboratory, E. I. DuPont de Nemours and Company, Aiken, SC 29801

R. Gregg

J. R. Hilley

115. Sunstrand Energy Systems, 4747 Harrison Avenue, Rockford, IL 61101

E. Kreuger

116-117. Teledyne Energy Systems, 110 W. Timonium Road, Timonium, MD 21093

W. J. Barnett

W. Osmeyer 